UNIVERSIDADE DE SÃO PAULO

ESCOLA DE ENFERMAGEM

TAMARA CAROLINA DE CAMARGO

AVALIAÇÃO DA ESTERILIZAÇÃO A VAPOR DO INSTRUMENTAL LAPAROSCÓPICO MONTADO:

ABORDAGEM LABORATORIAL 
TAMARA CAROLINA DE CAMARGO

\section{AVALIAÇÃO DA ESTERILIZAÇÃO A VAPOR DO INSTRUMENTAL LAPAROSCÓPICO MONTADO: ABORDAGEM LABORATORIAL}

Tese apresentada ao Programa de PósGraduação Enfermagem na Saúde do Adulto (PROESA) da Escola de Enfermagem da Universidade de São Paulo para obtenção do título de Doutor em Ciências.

Área de Concentração:

Enfermagem na Saúde do Adulto.

Orientadora:

Prof $^{\text {a }}$ Dra. Kazuko Uchikawa Graziano. 


\section{AUTORIZO A REPRODUÇÃO E DIVULGAÇÃO TOTAL OU PARCIAL DESTE TRABALHO, POR QUALQUER MEIO CONVENCIONAL OU ELETRÔNICO, PARA FINS DE ESTUDO E PESQUISA, DESDE QUE CITADA A FONTE.}

Assinatura:

Data:

Catalogação na Publicação (CIP)

Biblioteca "Wanda de Aguiar Horta"

Escola de Enfermagem da Universidade de São Paulo

Camargo, Tamara Carolina de

Avaliação da esterilização a vapor do instrumental laparoscópico montado: abordagem laboratorial / Tamara Carolina de Camargo. -- São Paulo, 2013.

$114 \mathrm{p}$.

Tese (Doutorado) - Escola de Enfermagem da Universidade de São Paulo.

Orientadora: $\operatorname{Prof}^{a}$ Dr $^{a}$ Kazuko Uchikawa Graziano

Área de concentração: Enfermagem na Saúde do Adulto

1. Esterilização 2. Laparoscopia 3. Instrumentos cirúrgicos 4. Enfermagem em centro cirúrgico 5. Enfermagem baseada em evidências 6 . Enfermagem I. Título. 


\section{FOLHA DE APROVAÇÃO}

Nome: Tamara Carolina de Camargo

Título: Avaliação da esterilização a vapor do instrumental laparoscópico montado: abordagem laboratorial.

Tese apresentada ao Programa de Pós-graduação Enfermagem na Saúde do Adulto (PROESA) da Escola de Enfermagem da Universidade de São Paulo para obtenção do título de Doutor em Ciências.

Aprovado em:

\section{Banca Examinadora}

Prof. Dr.

Julgamento:

Prof. Dr.

Julgamento:

Prof. Dr.

Julgamento:

Prof. Dr.

Julgamento:

Prof. Dr.

Julgamento:
Instituição:

Assinatura:

Instituição:

Assinatura:

Instituição:

Assinatura:

Instituição:

Assinatura:

Instituição:

Assinatura: 
Esta pesquisa foi desenvolvida na Escola de Enfermagem da Universidade de São Paulo, pelo Programa de Pós-Graduação Enfermagem na Saúde do Adulto (PROESA) com o apoio financeiro da FUNDAÇÃO DE AMPARO À PESQUISA DO ESTADO DE SÃO PAULO (FAPESP) e com incentivo da Pontifícia Universidade Católica de São Paulo (PUC-SP) por meio do Programa de Apoio e Incentivo à Pesquisa Docente, modalidade Capacitação Docente, do Conselho de Ensino, Pesquisa e Extensão (CEPE). 


\section{DEDICATÓRIA}

A meus pais José Antônio de Camargo e Neusa Blas de Camargo, pelo amor incondicional e por sempre compartilharem dos momentos difíceis e alegres de minha vida. Dedico meu amor, respeito e eterna gratidão. Amo vocês!

A meu marido Marcos José Lopes Simioni, pelo amor, carinho, paciência, compreensão, apoio e incentivo. Por ter compreendido minha ausência.

Por confiar em mim e nunca deixar de acreditar que eu conseguiria. Agradeço sua admiração e confiança. 


\section{AGRADECIMENTOS}

Primeiramente agradeço a Deus, pela proteção, condução de meus caminhos, fonte de toda inspiração e vida.

À Prof. Dra. KazukoVchikawa Graziano que, com toda a sua sabedoria e conhecimento, teve paciência, disposição e disponibilidade para minha orientação. Meu respeito profissional e sincera admiração pela sua sabedoria, humildade e determinação.

A minha irmã Patrícia, meu cunhado Ronaldo e meu querido sobrinho Matheus, pelo apoio, carinho e a torcida.

Aos colegas do Grupo de Pesquisa do CNPPQ "Tecnologia e qualidade na limpeza, desinfecção, esterilização de artigos e áreas e antissepsia", pelas valiosas discussões e contribuições enriquecedoras. Em especial, à Flávia Morais Gomes Pinto, Camila Quartim Bruna, Alda Graciele Claudio dos Santos Almeida e Karina Suzuki, pela colaboração, auxílio e participação nos experimentos de coleta de dados.

Às doutoras Marina Ishii e Michele Alfa, pela oportunidade de reflexão e contribuições metodológicas.

À Dra. Silma Pinheiro (em memória), pelos seus ensinamentos e oportunidade de compartilhar experiências, além do exemplo e respeito profissional

Ao Hospital Universitário da Universidade de São Paulo, pela disponibilidade. À equipe do Centro Obstétrico em nome da enfermeira Chang $\Upsilon_{i}$ Wei. À equipe do Centro de Material e Esterilização, em nome da enfermeira Cristiane de Lion Botero Couto Lopes, por colocar à disposição o equipamento para esterilização.

À equipe do laboratório de Biomateriais da Faculdade de Ciências Médicas e da Saúde, da Pontifícia Universidade Católica de São Paulo (PVC-SP), campus Sorocaba, pela parceria na realização dos experimentos. Em especial, à Dra. Eliana Duek e aos técnicos André Dutra Messias e Maria de Lourdes Matsuura Shikama.

Ao Laboratório de Microbiologia da Faculdade de Ciências Médicas da Santa Casa de São Paulo. Em especial, a microbiologista Cely Barreto da Silva, pelo auxílio e oportunidade de aprendizado na área de microbiologia.

Ao Lucas Petri Damiani, pelas contribuições estatísticas no cálculo das amostras e análise dos resultados.

Ao SENAI-Sorocaba, pelo cálculo da área dos instrumentais. Em nome dos professores Antonio Fernando dos Santos, Valter Roberto Serafim e José Roberto de Melo e do aluno Guilherme Lima Leite.

À PUC-SP, pela oportunidade de crescimento profissional, apoio, compreensão e suporte financeiro pela bolsa. 
Às colegas da Prefeitura Municipal de Sorocaba pelo apoio e suporte nos momentos em que precisei me ausentar para realização deste estudo.

À empresa 3M Brasil, em nome de $\mathcal{N}$ elyan A6do, pelo fornecimento dos Indicadores Biológicos para realização desta pesquisa.

Ao PROESA, pela oportunidade de crescimento acadêmico. Às funcionárias da secretaria da Pós-Graduação, pelas contribuições e auxílios.

À Fundação de Amparo à Pesquisa do Estado de São Paulo (FAPESP), pelo apoio financeiro para realização desta pesquisa.

A todos os amigos que direta ou indiretamente me acompanham nesta jornada... 
"A possibilidade de realizarmos um sonho é o que torna a vida interessante". Paulo Coelho 
Camargo TC. Avaliação da esterilização a vapor do instrumental laparoscópico montado: abordagem laboratorial. [tese]. São Paulo: Escola de Enfermagem, Universidade de São Paulo; 2013.

\section{RESUMO}

Esta pesquisa avaliou a segurança microbiológica da esterilização a vapor do instrumental laparoscópico reutilizável montado. Foram selecionados dois tipos de instrumental laparoscópico reutilizável: trocarte e pinça de dissecção de $5 \mathrm{~mm}$. Considerando a eficácia da limpeza como pré-requisito essencial para o processo de esterilização, a PRIMEIRA ETAPA da pesquisa, avaliou 66 instrumentos laparoscópicos, sendo 33 pinças e 33trocartes, submetidos a diferentes métodos de limpeza, avaliando como desfecho os resíduos orgânicos de proteína, hemoglobina e carboidrato, após contaminação intencional com sangue de placenta humana. Os métodos de limpeza testados foram: (1) limpeza manual com enxágue em água potável; (2) limpeza manual com enxágue em água potável, seguida de limpeza ultrassônica sem enxágue; (3) limpeza manual com enxágue em água potável, seguida de limpeza ultrassônica com enxágue em água potável e (4) limpeza manual com enxágue em água potável, seguida de limpeza ultrassônica com enxágue em água potável e último enxágue em água destilada esterilizada. Os experimentos foram acompanhados pelos grupos controle Positivo (sem limpeza) e Negativo, composto por instrumental laparoscópico novos sem contaminação intencional, avaliados após os procedimentos de limpeza (1) e (4). Para avaliação dos resíduos orgânicos, utilizou-se o kit Quantipro BCA para dosagem de proteínas, TMB One para hemoglobina, fenol 5\% e ácido sulfúrico para carboidrato, todos com leitura por espectrofotometria. O grupo controle Positivo evidenciou níveis médios de $332 \mu \mathrm{g} / \mathrm{cm}^{2}$ proteína, $30 \mu \mathrm{g} / \mathrm{cm}^{2}$ carboidrato e $417 \mu \mathrm{g} / \mathrm{cm}^{2}$ hemoglobina. Conforme esperado, o método de limpeza (4) apresentou desempenho superior quando comparado com o método (1), reduzindo $92 \%$ a mais de $\mu \mathrm{g} /$ proteína/pinça e $40 \%$ a mais de $\mu \mathrm{g} /$ carboidrato/pinça e por trocarte, embora esta superioridade não tenha sido observada de uma forma uniforme em todo o experimento. No grupo controle Negativo, os níveis máximos de proteína detectados foram $1,70 \mu \mathrm{g} / \mathrm{cm}^{2}$ e de carboidrato de $1,07 \mu \mathrm{g} / \mathrm{cm}^{2}$, não sendo detectada hemoglobina. A SEGUNDA

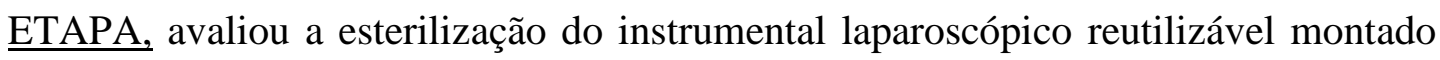
com contaminação desafio de três vezes $10^{6}$ esporos Geobacillus stearothermophillus 
ATCC 7953, impregnados em suporte de papel filtro extraídos do indicador biológico comercialmente disponível para monitoramento da autoclavação. Os experimentos microbiológicos foram acompanhados dos grupos controle Positivo (suporte do indicador biológico não submetido à esterilização) e controle Negativo (instrumentos laparoscópicos esterilizados desmontados com contaminação desafio). Como grupo Experimental, foram analisados 370 instrumentos laparoscópicos esterilizados montados, sendo 185 pinças e 185 trocartes. Três suportes de papel impregnados com os esporos foram introduzidos no interior de cada instrumento laparoscópico, precedidos de limpeza tipo (4), embalados em papel grau cirúrgico e submetidos à esterilização a vapor saturado sob pressão $\left(134^{\circ} \mathrm{C}\right.$ por 5 minutos). Com técnica asséptica, cada suporte de papel foi inoculado em meio de cultura de Tryptic Soy Broth (TSB), incubado a $56^{\circ} \mathrm{C}$ por 21 dias. Não sendo observado crescimento, as amostras foram submetidas a um choque térmico a $80^{\circ} \mathrm{C}$, por 20 minutos, para estimular a germinação, com reincubação por mais 72 horas. Não houve crescimento microbiano algum nas amostras do grupo Experimental. Os resultados dos grupos controles foram satisfatórios. O controle Positivo confirmou o desafio imposto aos experimentos e o controle Negativo apresentou resultados esperados de ausência de crescimento. Este estudo forneceu fortes evidências científicas para os Centros de Material e Esterilização sustentarem a segurança microbiológica da prática de esterilização do instrumental laparoscópico montado.

Palavras-chave: Esterilização, laparoscopia, instrumentos cirúrgicos, enfermagem em centro cirúrgico, enfermagem baseada em evidências e enfermagem. 
Camargo TC. Evaluation of steam sterilization of laparoscopic instruments assembled: laboratory approach. [thesis]. São Paulo (SP), Brasil: Escola de Enfermagem, Universidade de São Paulo; 2013.

\begin{abstract}
This study evaluated the microbiological safety of steam sterilization, the reusable laparoscopic instrument assembled. We selected two types of reusable laparoscopic instrument: trocar and dissecting forceps $5 \mathrm{~mm}$. Considering the efficacy of cleaning as an essential prerequisite for the sterilization process, the FIRST STEP evaluated 66 laparoscopic instruments, 33 trocars and 33 dissecting forceps, subjected to different cleaning methods evaluating outcome as organic waste protein, hemoglobin and carbohydrate after intentional contamination with blood from human placenta. Cleaning methods were tested: (1) manual cleaning rinse with potable water, (2) manual cleaning with rinsing in clean water, then cleaning ultrasonic without rinsing, (3) manual cleaning with rinsing in clean water, then cleaning ultrasonic rinse with potable water and (4) manual cleaning rinse with potable water, followed by ultrasonic cleaning with potable water rinse and final rinse in sterile distilled water. The experiments were accompanied by positive control groups (without cleaning) and negative, composed of laparoscopic instruments again without intentional contamination, assessed after the cleaning procedures (1) and (4). For evaluation of organic waste is used Quantipro BCA kit for the determination of protein, TMB One to hemoglobin, $5 \%$ phenol and sulfuric acid of carbohydrate with any read by spectrophotometry. The positive control group showed average levels of $332 \mu \mathrm{g} / \mathrm{cm}^{2}$ protein, carbohydrate $30 \mu \mathrm{g} / \mathrm{cm}^{2}$ and $417 \mu \mathrm{g} / \mathrm{cm}^{2}$ hemoglobin. As expected, the cleaning method (4) superior performance when compared with the method (1), reducing $92 \%$ more $\mu \mathrm{g} /$ protein/forceps and more than $40 \%$ $\mu \mathrm{g} / \mathrm{carbohydrate/forceps}$ and trocar, although this superiority has not been observed in a uniform manner throughout the experiment. In the negative control group maximum levels of protein detected were $1.70 \mu \mathrm{g} / \mathrm{cm}^{2}$ and $1.07 \mu \mathrm{g} / \mathrm{cm}^{2}$ carbohydrate was not detected hemoglobin. The SECOND STEP evaluated the sterilization of reusable laparoscopic instruments assembled with contamination challenge 3 times $10^{6}$ Geobacillusstearothermophillus spores ATCC 7953, impregnated strips filter paper extracted from commercially available biological indicator for monitoring steam sterilization. The experiments were accompanied microbiological positive
\end{abstract}


control groups (biological indicator spore strips non-sterile) and negative (laparoscopic instruments sterilized contamination disassembled challenge). As experimental group were analyzed 370 laparoscopic instruments sterilized assembled, 185 dissecting forceps and 185 trocars. Three spore strips of paper impregnated were introduced in laparoscopic instrument within each preceded by cleaning type (4), packed in surgical paper and subjected to saturated steam sterilization under pressure $\left(134^{\circ} \mathrm{C}\right.$ for 5 minutes $)$. With aseptic technique, each paper spore strip was inoculated into culture medium Tryptic Soy Broth (TSB) and incubated at $56^{\circ} \mathrm{C}$ for 21 days. No growth was observed, they were subjected to heat shock at $80^{\circ} \mathrm{C}$ for 20 minutes to stimulate germination, with more reincubation for 72 hours. There was no microbial growth in some samples of the experimental group. The results of the control groups were satisfactory. The Positive Control confirmed the challenge posed to experiments and the negative control presented results expected from the absence of growth. This study provides strong scientific evidence for the Centers for Material and Sterilization sustain the microbiological safety of the practice of sterilization of laparoscopic instruments assembled.

Keywords: Sterilization, laparoscopy, surgical instruments, operating room nursing, evidence-based nursing and nursing. 


\section{LISTA DE ILUSTRAÇÕES}

Figura 1 - Instrumental laparoscópico utilizado nos experimentos 41

Figura 2 - Contaminação do instrumental laparoscópico com sangue de 42 placenta humana

$\begin{array}{lll}\text { Figura } 3 \text { - Processos de limpeza } & 43\end{array}$

Figura 4 - Testes para avaliação do funcionamento da lavadora ultrassônica 44

Figura 5 - Esquema dos diferentes métodos testados para limpeza do 46 instrumental laparoscópico

Figura 6 - Procedimentos para extração dos resíduos orgânicos 47

Figura 7 - Testes indiretos para detecção dos resíduos orgânicos, com leitura 49 por espectrofotometria

Figura 8 - Indicador biológico comercialmente disponível para monitoramento dos ciclos de autoclavação

Figura 9 - Indicadores biológicos sendo desmontados para retirada dos suportes de papel impregnados com esporos Geobacillus stearothermophillus ATCC 7953

Figura 10 - Disposição dos indicadores biológicos nas pinças laparoscópicas

Figura 11 - Disposição dos indicadores biológicos nos trocartes

Figura 12 - Incubação dos meios de cultura

Figura 13 - Choque térmico dos meios de cultura 56

Figura 14 - Leitura final dos experimentos 66 


\section{LISTA DE GRÁFICOS}

Gráfico 1 - Curva-padrão de proteínas 49

Gráfico 2 - Curva-padrão de carboidratos 50

Gráfico 3 - Curva-padrão de hemoglobina 51

Gráfico 4 - Poder do teste para o tamanho amostral dos experimentos de $\quad 59$ avaliação da esterilização do instrumental laparoscópico montado 


\section{LISTA DE TABELAS}

Tabela 1 - Proporções utilizadas para construção da curva-padrão de proteínas 49

Tabela 2 - Proporções utilizadas para construção da curva-padrão de carboidratos

Tabela 3 - Proporções utilizadas para construção da curva-padrão de hemoglobina

Tabela 4 - Distribuição dos valores mínimo, máximo, mediana, média e desvio-padrão dos resíduos de carboidrato, proteína e hemoglobina em $\mu \mathrm{g} / \mathrm{cm}^{2}$ e em $\mu \mathrm{g} /$ pinça laparoscópica

Tabela 5 - Distribuição dos valores mínimo, máximo, mediana, média e desvio-padrão dos resíduos de carboidrato, proteína e hemoglobina em $\mu \mathrm{g} / \mathrm{cm}^{2}$ e em $\mu \mathrm{g} /$ trocarte

Tabela 6 - Comparação da redução percentual média dos resíduos orgânicos de proteína, carboidrato e hemoglobina no instrumental laparoscópico, após diferentes métodos de limpeza empregados

Tabela 7 - Resultado do pré-teste para avaliar a esterilização do instrumental laparoscópico montado

Tabela 8 - Resultado das culturas do suporte de papel do indicador biológico dentro do instrumental laparoscópico esterilizado montado 


\section{. LISTA DE QUADROS}

Quadro 1 - Comparação entre os valores médios de proteína, carboidrato e 73 hemoglobina presentes no instrumental laparoscópico, após contaminação intencional com sangue de placenta humana e no endoscópio após contaminação desafio com ATS, ambos sem limpeza

Quadro 2 - Comparação entre os valores médios de proteína, carboidrato e 75 hemoglobina presentes no instrumental laparoscópico submetidos a diferente métodos de limpeza, confrontados com os referenciados pelos diversos autores da literatura

Quadro 3 - Comparação entre os valores médios de proteína, carboidrato e 77 hemoglobina presentes no instrumental laparoscópico submetidos a diferente métodos de limpeza, confrontados com os referenciados por Alfa e Nemes (2004) para limpeza de lúmen

Quadro 4 - Síntese dos resultados da redução percentual média dos resíduos 78 orgânicos de proteína, carboidrato e hemoglobina no instrumental laparoscópico após diferentes métodos de limpeza, e os respectivos valores em $\mu \mathrm{g} /$ instrumental 


\section{LISTA DE SIGLAS}

AAMI Association for the Advancement of Medical Instrumentation

ABNT Associação Brasileiras de Normas Técnicas

ANVISA Agência Nacional de Vigilância Sanitária

AORN Association of periOperative Registered Nurses

ATCC American Type Culture Collection

ATP

Adesnosina Trifostato

ATS Artificial Soil Test

BCA Bicinchoninic Acid

BSA Bovine Serum Albumin

CEPE Conselho de Ensino, Pesquisa e Extensão

CME Centro de Material e Esterilização

DeCS Descritores em Ciências da Saúde

DP Desvio-Padrão

EE-USP Escola de Enfermagem da Universidade de São Paulo

ETO Óxido de Etileno

EUA Estados Unidos da América

FAPESP Fundação de Amparo à Pesquisa do Estado de São Paulo

FIOCRUZ Fundação Oswaldo Cruz

HEPA High Efficiency Particulate Air

IB Indicador Biológico

INCQS Instituto Nacional de Controle e Qualidade em Saúde

ISO International Organization for Standardization

LEM Laboratório de Ensaios Microbiológicos

MeSH Medical Subject Headings

NBR Norma Brasileira

PFGE Pulsed Field Gel Electrophoresis

POP Procedimento Operacional Padrão

PUC-SP Pontifícia Universidade Católica de São Paulo

RDC Resoluções de Diretoria Colegiada

SAL Sterility Assurance Level ou Nível de Segurança de Esterilidade

SENAI Serviço Nacional de Aprendizagem Industrial

SOBECC Associação Brasileira de Enfermeiros de Centro Cirúrgico, Recuperação Anestésica e Centro de Material e Esterilização

TMB Solução de Tetrametil Benzidina

TSB Tryptic Soy Broth ou Caldo Tríptico de Soja

UFC Unidades Formadoras de Colônias

USS Ultrassônica 


\section{LISTA DE SÍMBOLOS}

$\begin{array}{ll}{ }^{\circ} \mathrm{C} & \text { Graus Celsius } \\ \% & \text { Porcentagem } \\ < & \text { Menor } \\ > & \text { Maior } \\ \leq & \text { Menor ou igual } \\ \geq & \text { Maior ou igual } \\ \mu \mathrm{g} & \text { Micrograma }\left(10^{-6} \mathrm{~g}\right) \text { - unidade de massa } \\ \mu \mathrm{L} & \text { Microlitro }\left(10^{-6} \mathrm{~L}\right)-\text { unidade de volume ou capacidade } \\ \mu \mathrm{mole} & \text { Micromole }\left(10^{-6} \mathrm{moles} \text { de soluto por litro de solução) }\right. \\ \mathrm{cm} & \text { Centímetro }\left(10^{-2} \mathrm{~m}\right)-\text { unidade de comprimento } \\ \mathrm{cm} & \text { Centímetro quadrado - unidade de área } \\ \mathrm{EU} & \text { Endotoxinunit } \\ \mathrm{kHz} & \text { Kilohertz - unidade de medida de frequência } \\ \mathrm{mg} & \text { Miligrama }\left(10^{-3} \mathrm{~g}\right)-\text { unidade de massa } \\ \mathrm{mL} & \text { Mililitro }\left(10^{-3} \mathrm{~L}\right)-\text { unidade de volume ou capacidade } \\ \mathrm{mm} & \text { Milímetro }\left(10^{-3} \mathrm{~m}\right) \text { - unidade de comprimento } \\ \mathrm{NaOH} & \text { Hidróxido de sódio } \\ \mathrm{nm} & \text { Nanômetro }\left(10^{-9} \mathrm{~m}\right) \text { - unidade de comprimento } \\ \mathrm{pH} & \text { Potencial hidrogeniônico } \\ \mathrm{rpm} & \text { Rotação por minuto } \\ \mathrm{V} & \text { Volts - unidade de tensão elétrica } \\ \mathrm{W} & \text { Watt - unidade de potência } \\ \mathrm{w} / \mathrm{v} & \text { Peso por volume (gramas por 100mL) } \\ \Sigma & \text { Somatório } \\ & \end{array}$




\section{SUMÁRIO}

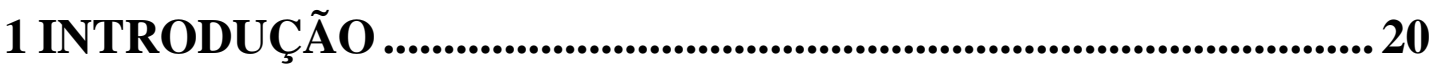

2 REFERENCIAL TEÓRICO ............................................................. 25

2.1 LIMPEZA ............................................................................................................ 25

2.2 ESTERILIZAÇÃOA VAPOR SATURADO SOB PRESSÃO..................... 29

2.3 ESTERILIZAÇÃO DO INSTRUMENTAL LAPAROSCÓPICO

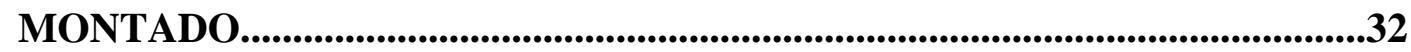

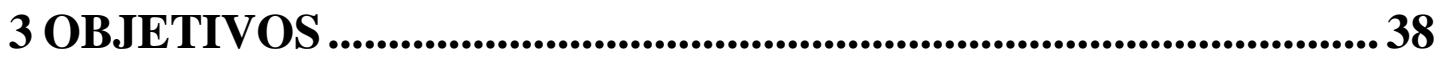

4 MATERIAL E MÉTODO ............................................................... 40

4.1 TIPO DE PESQUISA ........................................................................................ 40

4.2 LOCAIS DA PESQUISA …......................................................................... 40

4.3 AMOSTRA ……............................................................................................ 41

4.4 COLETA DE DADOS ................................................................................. 41

4.4.1Avaliação da eficácia de diferentes métodosde limpeza do instrumental laparoscópico ................................................................................... 42

4.4.2A valiação da esterilização do instrumental laparoscópico montado .... 52

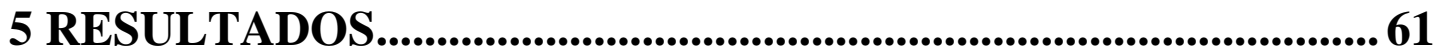

6 DISCUSSÃO

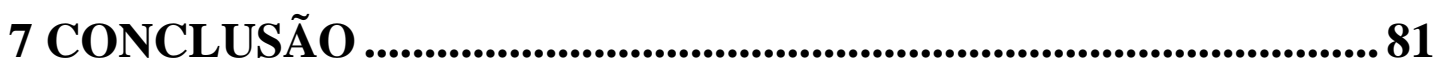

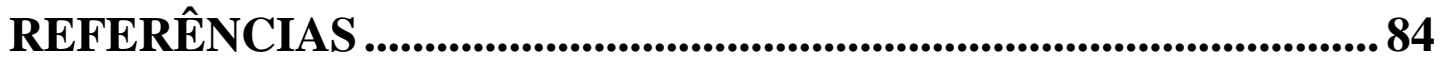

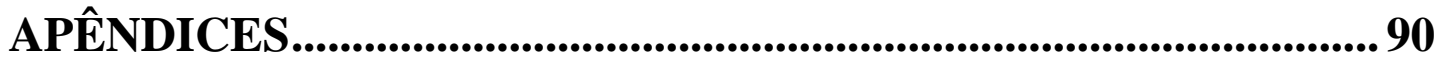

A Controle de esterilização dos meios de cultura ............................................. 90

B Registro dos resultados dos testes de análise dos resíduos orgânicos de proteína, carboidrato e hemoglobina no instrumental laparoscópico............91

C Formulário de registro dos resultados dos testes de esterilidade do préteste

D Formulário de registro dos resultados dos testes de esterilidade com instrumental laparoscópico montado .................................................................99

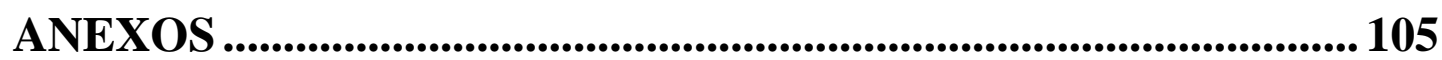

1 Cálculo da área da superfície do instrumental laparoscópico ................... 105

2 Ciclos de esterilização do instrumental laparoscópico.................................107

2 Ciclos de esterilização dos meios de cultura .................................................. 111 
1 INTRODUÇÃO 


\section{INTRODUÇÃO}

A cirurgia videolaparoscópica é uma inovação tecnológica que surgiu como alternativa aos procedimentos cirúrgicos, diagnósticos e terapêuticos, que habitualmente se realizavam com laparotomia a "céu aberto". Atualmente, a técnica é aceita em diversas especialidades, sendo a abordagem de primeira escolha para muitos procedimentos, como por exemplo, o tratamento da doença de vesícula biliar (Chandio et al., 2009).

De forma geral, a laparoscopia baseia-se na visualização e manipulação da cavidade abdominal e de seu conteúdo através de pequenas incisões na pele, por onde se introduzem trocartes que vão permitir a inserção de instrumentos e de ópticas acopladas a microcâmeras para captação de imagens. Como a cavidade abdominal é virtual, é necessária sua transformação em cavidade real para facilitar a visualização. Isto é alcançado por meio do chamado pneumoperitônio, que se constitui na distensão abdominal com a insuflação ativa de gás carbônico; este é inerte e, rapidamente, difundido na corrente sanguínea sem acúmulo excessivo. É fundamental ainda a iluminação da região a ser manipulada, por meio de fonte de luz externa, com a transmissão da luminosidade para o interior da cavidade através de um cabo de fibra óptica (Nasiet al., 1993; Dimas et al.,2006).

Esta técnica trouxe indiscutíveis vantagens, como raras complicações infecciosas, abreviação do tempo de internação, melhores resultados estéticos, rápida recuperação do paciente com breve reintegração social e profissional (Nasi et al., 1993; Chandio et al., 2009). O reconhecimento de todas estas vantagens foi acompanhado por novos desafios, dentre eles, o estabelecimento de diretrizes para o processamento seguro do instrumental e seus acessórios, marcados como sendo de conformação complexa, que por definição possuem lúmen inferior a $5 \mathrm{~mm}$ ou com fundo cego, espaços internos inacessíveis para a fricção direta, reentrâncias ou válvulas (Brasil, 2012).

O Centro de Material e Esterilização (CME) é a unidade de apoio técnico responsável pelo processamento dos materiais utilizados na assistência à saúde, cabendo ao responsável técnico decidir pelos protocolos a serem empregados, descrevendo-os em forma de Procedimento Operacional Padrão (POP), com base em referencial científico atualizado, sendo amplamente divulgado e disponível para 
consulta (Brasil, 2012). No quesito esterilização, a escolha do método deve considerar as características do agente esterilizante e a compatibilidade com a natureza do produto a ser esterilizado (Rutala e Weber, 2008).

O vapor saturado sob pressão é o método de esterilização indicado para o instrumental termorresistente por reunir vantagens como baixo valor $\mathrm{D}^{1}$, alta difusibilidade e penetrabilidade do agente esterilizante, rapidez, atoxicidade e menor custo (Rutala e Weber, 2008). Atualmente, a indústria disponibiliza instrumental para videolaparoscopia termorresistente.

Entre os profissionais da saúde, existe um arraigado conceito que, para o alcance do sucesso da esterilização por meio da autoclave, é necessário o contato direto do vapor com todas as superfícies dos materiais, sem se considerar os princípios físicos do calor latente. Conceitos arraigados, fundamentados em tradições, devem ser questionados, buscando evidências científicas fortes, para subsidiar as tomadas de decisões na prática assistencial (Galvão, Sawada e Rosse, 2002).

Por raciocínio dedutivo, acredita-se que a prática de autoclavar instrumental laparoscópico montado está assegurada pelos princípios físicos do calor latente e posterior condução térmica. Dentre os instrumentais cirúrgicos, há diversos materiais com conformação complexa que vêm montados de fábrica, como as frezas ortopédicas e os afastadores articulados.

Apesar dos referenciais teóricos da física na esterilização a vapor, vários documentos das organizações oficiais e não oficiais, nacionais e internacionais, considerados, como referência na área de Centro Cirúrgico (CC) e CME, recomendam que todos os materiais, incluindo nestes os de viodelaparoscopia, estejam desmontados, antes de serem autoclavados (Committee on Infection Control in the Handling of Endoscopic Equipment - Guidelines for preparation of laparoscopic instrumentation, 1980; AAMI, 2006; Rutala e Weber 2008; Padoveze, Quelhas e Nakamura, 2010). Há também documentos que não enfatizam esta recomendação (AORN, 2012; Brasil, 2012). Não resta dúvida de que na autoclavação de materiais desmontados a condução térmica tem a melhor condição.

\footnotetext{
${ }^{1}$ Valor D (tempo de redução decimal): é o intervalo de tempo, à temperatura constante, necessário para reduzir $90 \%$ da população microbiana inicial (Rutala e Weber, 2008).
} 
Por outro lado, sendo os acessórios laparoscópicos instrumentos complexos com várias peças de tamanhos pequenos, se esterilizados totalmente desmontados trazem transtornos às equipes cirúrgicas no momento de sua montagem no campo operatório. Destaca-se que alguns instrumentadores cirúrgicos desconhecem sua montagem correta, comprometendo sua funcionalidade, gerando estresse e tumultuando o início do procedimento cirúrgico (Caregnato e Lautert, 2005).

A autoclavação de instrumental laparoscópico previamente montado é uma realidade identificada por uma pesquisa, com amostra composta por 263 profissionais de enfermagem, em que $37 \%$ dos respondentes referiram que nas suas instituições esterilizam o instrumental laparoscópico montado (Feitosa, Camargo e Graziano, 2011). Essa prática visa à otimização do tempo e à segurança na montagem, porém, por outro lado, há equipes cirúrgicas que questionam a Enfermagem do CME se a esterilização dos instrumentos laparoscópicos montados está assegurada.

Esta preocupação motivou a autora desta tese, a desenvolver como dissertação de mestrado (Camargo, 2007), uma pesquisa experimental com o objetivo de avaliar a eficácia do processo de esterilização a vapor do instrumental laparoscópico montado, desafiando com suspensão de esporos do Geobacillus stearothermophilus ATCC 7953 na densidade de $10^{6} \mathrm{UFC} / \mathrm{mL}$. Mas, nas condições do experimento, houve recuperação do micro-organismo-teste em três peças de uma mesma pinça $(3 / 48)$ e em três peças de um mesmo trocarte $(3 / 60)$. Os resultados obtidos refutaram a hipótese inicial da pesquisa, quanto à segurança da autoclavação das pinças laparoscópicas e de trocartes montados. Diante da constatação de uma realidade nacional de esterilização do instrumental laparoscópico montado, decidiuse retomar a questão de pesquisa com uma nova abordagem metodológica, também desafiadora, para subsidiar uma metanálise futura em uma revisão sistemática das produções científicas.

Considerando a eficácia da limpeza, como pré-requisito fundamental para garantia do processo de esterilização, a proposta de Camargo para o doutorado foi avaliar inicialmente a eficácia de diferentes métodos de limpeza do instrumental laparoscópico reutilizável praticados pelos CMEs para, posteriormente, avaliar a esterilização do instrumental laparoscópico reutilizável montado. Considerando a conformação complexa do instrumental, a resposta da garantia da limpeza foi 
Tamara Carolina de Camargo

considerada não menos importante que a questão central da tese. Na avaliação microbiológica, optou-se pela inserção em cada instrumental de três suportes de papel filtro impregnados com esporos do Geobacillus stearothermophilus ATCC 7953 na densidade de $10^{6}$ UFC/suporte, extraídos dos indicadores biológicos comercialmente disponíveis e utilizados rotineiramente no $\mathrm{CME}$, para monitorar a efetividade da esterilização.

Isto posto, a questão norteadora principal da pesquisa consistiu em: o processo de esterilização, a vapor saturado sob pressão, do instrumental laparoscópico reutilizável montado é microbiologicamente seguro? Teve-se como hipótese que a autoclavação do instrumental laparoscópico montado é microbiologicamente segura. 


\section{REFERENCIAL TEÓRICO}

\subsection{LIMPEZA}

A limpeza é o processo de remoção de sujidades orgânicas e inorgânicas, redução da carga microbiana presente nos produtos para saúde, utilizando água, detergentes, produtos e acessórios de limpeza, por meio de ação mecânica (manual ou automatizada), atuando em superfícies internas (lúmen) e externas, tornando o produto seguro para o manuseio e preparado para desinfecção ou esterilização (Graziano, 2003; Rutala e Weber, 2008; Ribeiro, 2010; Brasil, 2012). Indiscutivelmente, a etapa da limpeza é considerada fundamental para a eficácia dos processos subsequentes, pois a sujidade atua como barreira física protegendo os micro-organismos e impedindo a ação dos agentes desinfetantes e esterilizantes (Graziano 2003; AAMI, 2006; Rutala e Weber, 2008).

A escolha do método de limpeza depende das características do dispositivo. $\mathrm{O}$ instrumental laparoscópico é considerado um material de conformação complexa por possuir lumens longos e estreitos $(<5 \mathrm{~mm})$, válvulas, superfícies com ranhuras, encaixes e mecanismos de acionamento de pinças, constituindo um desafio para o processo de limpeza (AAMI, 2006; Ribeiro, 2010).

Boas práticas de instrumentação cirúrgica, como a limpeza do instrumental imediatamente após o uso, evitam o ressecamento do sangue e de outros fluídos corpóreos. No CME, recomenda-se a pré-limpeza dos materiais, que consiste em aplicar jatos de água para remoção da sujidade grosseira e imersão em soluções tensoativas para limpeza manual ou submetê-los ao processo automatizado ou pela combinação de ambas (AAMI, 2006; Rutala e Weber, 2008).

A limpeza manual é recomendada para dispositivos delicados e complexos, sendo complementada pela limpeza ultrassônica (AAMI, 2006; Rutala e Weber, 2008). Para facilitar a remoção da sujidade, deve-se imergir o instrumental desmontado em solução de detergente cuidadosamente selecionado, conforme o grau e tipo de sujidade, preencher os lumens com auxílio de seringa, para garantir o contato da solução com todas as superfícies do material, seguindo as orientações do fabricante quanto à diluição do tensoativo, temperatura da solução e tempo de contato. Utilizar escovas macias e artefatos que permitam friccionar todas as 
superfícies do material, incluindo os lumens; a fricção deve ser realizada debaixo da água para minimizar a dispersão de aerossol (AAMI, 2006). Variações das técnicas podem ocorrer entre profissionais, constituindo uma limitação da limpeza manual (Ribeiro, 2010).

A limpeza automatizada proporciona a repetitividade do processo, reduz riscos ocupacionais a resíduos biológicos e químicos e aumenta a produtividade (Ribeiro, 2010). As lavadoras termodesinfetadoras removem a sujidade por meio de jatos de água associados ao detergente; as lavadoras de descarga são um tipo de lavadora termodesinfetadora destinada ao processamento de utensílios, como comadres e papagaios e as lavadoras ultrassônicas que agem pelo fenômeno da cavitação e implosão em que ondas de energia acústica propagam-se em meio líquido, gerando bolhas microscópicas que, ao entrarem em contato com a superfície do material, implodem e geram uma área de vácuo que remove a sujidade aderida ao material (Rutala e Weber, 2008; Psaltikidis e Ribeiro, 2011). O equipamento deve permitir a monitorização das etapas do ciclo de limpeza, pois, falhas no sistema automatizado podem comprometer o processo (Ribeiro, 2010).

A limpeza automatizada em lavadora ultrassônica com conector para canulados e tecnologia de fluxo intermitente é obrigatória, para os materiais com lúmen de diâmetro interno inferior a 5mm (Brasil, 2012). Estes equipamentos dispõem de conexões e outros dispositivos que facilitam o acesso, sejam de água ou detergente em todas as superfícies dos materiais (Ribeiro, 2010).

O enxágue deve ser realizado com água potável abundante que atenda a Portaria Ministerial $\mathrm{n}^{\mathrm{o}} 2914$ de 12/12/2011, com o intuito de remover detritos e sujidades desprendidos dos materiais e resíduos dos detergentes por ação do fluxo de água; devem-se utilizar pistolas de água sob pressão para os materiais com lúmen (Psaltikidis e Ribeiro, 2011; Brasil, 2011; Brasil, 2012). Para o enxágue final, recomenda-se uso de água tratada, livre de contaminantes, endotoxinas e minerais, de modo a prevenir reações pirogênicas nos pacientes (Rutala e Weber, 2008; Brasil, 2012).

Deve-se estabelecer POP com descrição de cada passo do processo de limpeza e seus aspectos essenciais, para evitar variação entre os membros da equipe, além de aplicar metodologias de validação e verificação dos níveis de limpeza. 
Existe uma variedade de métodos para avaliar os resultados do processo de limpeza, disponíveis e aplicáveis para a prática dos CME.

A análise visual simples ou amplificada com o auxílio de lentes intensificadoras de imagem iluminada de, no mínimo, oito vezes de aumento é obrigatória (Brasil, 2012). Como padrão para o grau de limpeza, é aceito que o material esteja visivelmente limpo (AAMI, 2006; Rutala e Weber, 2008). No entanto, esta medida não tem sido considerada suficiente para avaliar a limpeza, visto que pode haver resíduos de proteínas em superfícies aparentemente limpas, além da impossibilidade de inspecionar lumens longos e estreitos, compartimentos internos e áreas articuladas ou cobertas (SOBECC, 2009).

$\mathrm{Na}$ atualidade, há testes comercialmente disponíveis para verificação da eficácia da limpeza como:

- HemoCheck-S ${ }^{\circledR}$ teste de pronto uso indicado para monitorar a presença de sangue em superfícies, por meio de reação enzimática que promove rápida alteração de cor do reagente, proporcionando a detecção de até $0,1 \mu \mathrm{g}$ de resíduo de sangue;

- Biotrace Pro-tec ${ }^{\circledR}$ são indicadores que têm como base a detecção de resíduo orgânico de proteínas por meio de swab, sendo o nível de resíduo da superfície indicado pela cor da reação do teste;

- 3M Clean-Trace ${ }^{\mathrm{TM}}{ }^{\circledR}$ são indicadores que têm como base a detecção de resíduo orgânico de proteínas por meio de swab, com sensibilidade de $50 \mu \mathrm{g} / a$ rea (Surface protein plus ${ }^{\circledR}$ ) ou $3 \mu \mathrm{g} / a$ rea (Surface protein high sensitivity ${ }^{\circledR}$ ), também pode ser detectada a presença de Adenosina Trifostato (Surface $\mathrm{ATP}^{\circledR}$ e Water total $\mathrm{ATP}^{\circledR}$ ), fonte de energia presente em células vivas. Estes testes são capazes de detectar resíduos de matéria orgânica e micro-organismos em equipamentos, instrumentos cirúrgicos e superfícies, que permitem atestar, medir e validar a eficácia da limpeza (Alfa, 2006; SOBECC, 2009).

Alternativamente, há outros métodos fotocolorimétricos para avaliar a limpeza da superfície dos materiais, por meio da detecção dos níveis de proteína, como o método de Biureto, o ensaio de Ninhydrina e o ensaio de Bradford (Alfa, 2006). Nestes métodos, são utilizadas reações químicas que resultam em soluções 
coloridas, sendo a intensidade da cor produzida proporcional à concentração da substância que está sendo dosada.

Há testes especialmente desenvolvidos, para verificação da eficácia da limpeza pela ação mecânica nos equipamentos:

- Tosi ${ }^{\circledR}$ teste pronto uso indicado para monitoração de limpeza em lavadoras termodesinfectoras. Permite avaliação imediata por inspeção visual simples. Utiliza soil teste de equivalência ao sangue humano, aderido sobre uma superfície de uma lâmina de aço inoxidável com cobertura plástica. O teste é posicionado nas bandejas de lavagem, colocadas em diversas posições no interior das lavadoras. Depois das fases de limpeza e desinfecção, a eficácia da lavadora é avaliada por inspeção visual, esperando-se a remoção completa do soil teste.

- Tosi LumCheck ${ }^{\circledR}$ indicado para monitoração de limpeza em canulados submetidos à limpeza em lavadoras ultrassônicas com retrofluxo. O teste com simulador de sujidade é introduzido no interior do lúmen do instrumentoteste, denominado porta-lúmen, e este é conectado ao dispositivo para limpeza de lúmen da lavadora ultrassônica. Ao término do ciclo de limpeza, procede-se a inspeção visual do simulador de sujidade; espera-se a remoção completa da sujidade-teste.

- SonoCheck ${ }^{\circledR}$ teste pronto, uso indicado para monitorar o nível de energia ultrassônica durante a limpeza dos instrumentais cirúrgicos, com resultado imediato. O processo de cavitação aciona uma reação química da ampola do SonoCheck ${ }^{\circledR}$, mudando da cor verde para amarelo (Alfa, 2006; SOBECC, 2009).

- Teste de Resíduo Soil Test ${ }^{\circledR}$ é um produto com formulação química atóxica, contendo materiais que simulam as características de sangue presente nos instrumentais. É uma mistura pronta, acondicionada em recipientes individuais que contêm um pincel próprio para aplicação sobre os instrumentais. Ao término do ciclo de limpeza, procede-se à inspeção visual do simulador de sujidade; espera-se a remoção completa da sujidade-teste (Bergo e Graziano, 2005; Bergo 2006). 


\subsection{ESTERILIZAÇÃO A VAPOR SATURADO SOB PRESSÃO}

A esterilização é classicamente conceituada, como um processo de destruição de todas as formas de vida microbiana, incluindo os micro-organismos esporulados. Atualmente, com o conhecimento sobre o comportamento e diversidade dos microorganismos e a cinética da morte microbiana, o conceito de esterilização passa a assumir um entendimento mais complexo, envolvendo estatística (Graziano, 2003; Rutala e Weber, 2008).

A probabilidade da inativação microbiana é, atualmente, referida pelo nível de segurança de esterilidade (Sterility Assurance Level - SAL). Um produto é considerado esterilizado, quando a probabilidade de sobrevivência de um único micro-organismo for menor do que $10^{-6}$ Unidades Formadoras de Colônias (UFC), ou seja, 1:1.000.000. Em suma, o SAL é uma estimativa de letalidade do processo de esterilização, obtida por um cálculo conservador no qual a escolha do parâmetro de $10^{-6}$ foi arbitrado e não associado com qualquer resultado adverso (Rutala e Weber, 2008).

Pinto, Kaneko e Ohara (2010) reforçam que organismos expostos a agentes letais não morrem todos simultaneamente; portanto, a ausência de todos os organismos viáveis irá ocorrer em um tempo infinito de exposição ao agente. Esterilidade é um estado absoluto e que não pode ser garantido. O cuidado desenvolvido do processo esterilizante apenas aumenta a probabilidade de sucesso no sentido da esterilidade.

A inativação dos micro-organismos por agentes esterilizantes envolve dano irreversível de moléculas essenciais à célula. Um micro-organismo é definido como morto, quando não mais prolifera em meios de cultura onde usualmente isto ocorria. A expressão "livre de formas demonstráveis de vida" tem sido empregada como sinônimo de "estéril" (Pinto, Kaneko e Ohara, 2010).

A morte microbiana se dá em curva exponencial, sendo o tempo de redução decimal (valor D) definido como intervalo de tempo, à temperatura constante, necessário para reduzir 90\% da população microbiana inicial (Rutala e Weber, 2008). Esse valor, expresso em minutos, é utilizado para estabelecer parâmetros de esterilização por diferentes métodos. O tempo de exposição ao processo de esterilização deverá garantir um nível de segurança de morte microbiana na ordem de 
$10^{-6}$, no qual por 12 vezes o valor $\mathrm{D}$ foi aplicado a um material com contaminação inicial de $10^{6}$ UFC (Padoveze, 2010; Padoveze e Graziano, 2011).

A escolha do método de esterilização depende, sobretudo, da natureza dos materiais quanto à termorresistência. Os materiais sensíveis ao calor e à umidade requerem tecnologias de esterilização à baixa temperatura, como por exemplo, óxido de etileno, gás plasma de peróxido de hidrogênio e vapor à baixa temperatura e formaldeído. Para os materiais resistentes ao calor, o processo de esterilização recomendado é a esterilização a vapor saturado sob pressão, por meio de equipamento denominado autoclave, em razão da eficiência, segurança, baixo valor $\mathrm{D}$, alta difusibilidade, alta penetrabilidade, rapidez, atoxicidade, economia e baixo risco ocupacional (Rutala e Weber, 2008).

O mecanismo de esterilização das autoclaves está relacionado com o calor latente. $\mathrm{O}$ vapor saturado sob pressão em contato com a superfície fria dos materiais dispostos dentro da autoclave sofre condensação, liberando o calor latente de vaporização que molha e aquece simultaneamente os materiais. Este calor acarreta termocoagulação das proteínas e morte dos micro-organismos, ou seja, a esterilização fundamenta-se na troca de calor entre o meio e o objeto a ser esterilizado (Perkins, 1983; Padovezes, Quelhas e Nakamura, 2011). No processo de autoclavação, o calor latente de vaporização é caracterizado pela condensação do vapor da água, à pressão constante, sem variação de temperatura (Francis e Pashley, 2009).

Para a garantia da eficiência do processo de esterilização, é essencial a combinação entre o intervalo de tempo de exposição e temperaturas $\left(121^{\circ} \mathrm{C} \mathrm{ou}\right.$ $134^{\circ} \mathrm{C}$ ) adotados nos ciclos. O tempo de exposição do material em uma autoclave abrange três componentes: intervalo de penetração do vapor, necessário para que a carga atinja a temperatura da câmara; tempo de esterilização propriamente dita que é o menor intervalo necessário, para que ocorra a destruição de todas as formas de vida microbiana, podendo variar dependendo da temperatura empregada e da carga microbiana inicial e, finalmente, o intervalo de confiança, que é o adicional utilizado para garantir uma maior segurança da esterilização, geralmente, correspondendo ao dobro do tempo necessário para eliminação de $10^{6}$ de esporos bacterianos (Graziano, 2003; AAMI, 2006). 
Após o término do intervalo de exposição, inicia-se a exaustão do vapor do interior da câmara pelo dreno da autoclave, com o auxílio de uma bomba de vácuo ou ejetor de vapor tipo Venturi. A pressão negativa durante o período de vácuo associada à temperatura residual na câmara da autoclave e nos pacotes promovem o processo de secagem (AAMI, 2006).

Há necessidade de se estabelecer padrões no preparo e acondicionamento dos materiais a serem esterilizados. As embalagens devem ser permeáveis ao vapor, resistentes à umidade, flexíveis e não podem permitir a penetração do microorganismo, após o processo de autoclavação. Sua composição deve estar livre de produtos tóxicos, corantes e não deve liberar resíduo. Devem favorecer o fechamento, selagem e apresentarem facilidade na abertura sem ocasionar risco de recontaminação de seu conteúdo (Graziano, 2003).

Os parâmetros críticos do processo de esterilização devem ser monitorados. A legislação vigente (Brasil, 2012), que dispõe sobre requisito de boas práticas para o processamento de produtos para saúde, destaca:

- teste para avaliar o desempenho do sistema de remoção de ar (Bowie \& Dick) da autoclave assistida por bomba de vácuo, realizado no primeiro ciclo do dia;

- registro dos indicadores físicos (tempo, temperatura e pressão) de cada ciclo de esterilização;

- monitoramento do processo de esterilização em cada carga em pacote desafio com integradores químicos (classe cinco ou seis). Os indicadores integradores (classe cinco) reagem com todos os parâmetros críticos do ciclo de esterilização. No caso das autoclaves, monitoram temperatura, tempo mínimo de exposição e a qualidade do vapor; os indicadores emuladores ou simuladores (classe seis) reagem com todos os parâmetros críticos de um ciclo, específico de esterilização, proporcionando alta sensibilidade e especificidade no monitoramento (Calicchio et al., 2011);

- monitoramento diário do processo de esterilização com indicador biológico, em pacote desafio, que deve ser posicionado no ponto de maior desafio ao processo de esterilização definido durante estudos térmicos de desempenho do equipamento de esterilização. Os indicadores biológicos são preparações padronizadas contendo em torno de $10^{6}$ esporos bacterianos, comprovadamente resistentes ao tipo de esterilização; para o vapor, indica-se o Geobacillus stearothermophilus ATCC 7953 (Rutala e Weber, 2008); 
- na esterilização de produtos para saúde implantáveis, deve ser adicionado um indicador biológico a cada carga, sendo liberada após a leitura negativa do indicador biológico.

Os equipamentos devem estar em perfeitas condições de funcionamento e qualificados. As autoclaves devem possuir qualificação de instalação, de operação e de desempenho, realizada por empresas capacitadas com periodicidade mínima anual (Brasil, 2012).

\subsection{ESTERILIZAÇÃO DO INSTRUMENTAL LAPAROSCÓPICO MONTADO}

Uma revisão bibliográfica foi realizada sobre a segurança na autoclavação do instrumental laparoscópico montado. Utilizou-se o vocabulário controlado dos Descritores em Ciências da Saúde (DeCS) e do Medical Subject Headings (MeSH): esterilização/sterilization, instrumentos cirúrgicos/surgical instruments. A busca foi complementada por vocábulos livres (esterilização a vapor/steam sterilization e montado/assembled) nos idiomas português e inglês, utilizando o operador booleano AND, entre os termos. Foram encontrados apenas dois artigos com abordagens relacionadas ao problema de interesse.

Dentre eles, um artigo original de Dallas - Estados Unidos da América (EUA), publicado em 1991, relata um estudo laboratorial com a hipótese de que o instrumental de laparoscopia montado alcança a mesma segurança da esterilidade, quando comparado ao instrumental desmontado (Marshburn et al., 1991). O outro artigo, localizado pela busca dos links relacionados ao artigo anterior (Related Links), relata uma publicação original do Mississippi (EUA) do ano de 1995, onde os autores realizaram um estudo laboratorial com o objetivo de determinar a eficácia da esterilização a vapor dos instrumentos laparoscópicos com os lumens vedados com carne (massa para hambúrger) e uma alta concentração de micro-organismos em seu interior (Voyles et al., 1995). Esse último artigo, embora não caracterize exatamente uma pesquisa com instrumental montado, foi analisado por considerar a vedação dos lumens como um desafio para o não contato direto do vapor na superfície dos lumens, e o calor transmitiu-se por meio do material pelo princípio do calor latente, que é o referencial teórico que suporta a hipótese da presente pesquisa. 
Tamara Carolina de Camargo

No primeiro estudo, Marshburn e seus colaboradores (1991) utilizaram suspensões de bactérias na forma vegetativa (Serratia marcescens) e esporuladas (Bacillus subtilis e Bacillus stearothermophilus) para contaminação desafio de duas pinças (Grasper e bipolar) e dois trocartes $(5 \mathrm{~mm}$ e $10 \mathrm{~mm}$ ) laparoscópicos. As suspensões bacterianas foram inoculadas por meio de uma haste com algodão enrolado na ponta (swab), previamente esterilizada, em dez locais considerados mais críticos para retenção da matéria orgânica e, consequentemente, de difícil limpeza, sendo três locais no trocarte de $10 \mathrm{~mm}$, cinco no trocarte de $5 \mathrm{~mm}$, um na pinça Grasper e um na pinça bipolar. Os autores utilizaram dois diferentes protocolos para testar a eficácia da esterilização: no Protocolo 1, os instrumentos eram desmontados, contaminados por esfregaço com as suspensões microbianas descritas em diferentes locais, usando o swab. Em seguida, sem lavagem prévia, os instrumentos foram montados, embalados e esterilizados em óxido de etileno - ETO (1:45 horas de tempo de esterilização e 20 horas de aeração) e a vapor (4 minutos a $132^{\circ} \mathrm{C}$ ); no Protocolo 2, os materiais foram submetidos à mesma contaminação desafio, lavados manualmente e divididos em três grupos sendo: (1) instrumentos montados, (2) instrumentos desmontados e esterilizados a vapor (4 minutos a $132^{\circ} \mathrm{C}$ ), e (3) instrumentos mantidos desmontados em condições ambientais sem passar pelo processo de esterilização, constituindo-se o Grupo Controle Positivo. Foram colhidas amostras para cultura em triplicata, por meiode swabs esterilizados e umedecidos com caldo TSB, em cada local previamente contaminado. Os swabs foram colocados em tubos com 3,5mL do meio de cultura TSB e as subculturas em placas de ágar sangue incubados por sete dias, nas temperaturas especificadas para os microorganismos testes (Serratia marcescens e Bacillus subtilis a $35^{\circ} \mathrm{C}$; Geobacillus stearothermophilus a $56^{\circ} \mathrm{C}$ ). Com a aplicação do Protocolo 1, todas as bactérias vegetativas morreram, porém, os esporos sobreviveram em 30\% das amostras esterilizadas pelo ETO (9/30) e em 13\% das amostras esterilizadas pelo vapor (4/30); com o Protocolo 2, obteve-se $4 \%$ de culturas positivas para os instrumentos montados (1/24), $3 \%$ para os instrumentos desmontados (1/30) e $100 \%$ para o Controle Positivo (30/30). Os autores concluem que um alto nível de desinfecção pôde ser obtido com limpeza e autoclavação de instrumentos laparoscópicos montados, considerando um método aceitável para preparação do instrumento para uso cirúrgico, observando que a pesquisa utilizou contaminação desafio, em 
umadensidade microbiana muito acima da encontrada na prática, após a limpeza. Ressaltam, ainda, que desde a conclusão desse estudo, o instrumento laparoscópico tem sido autoclavado montado nos hospitais onde os autores mantem atividades profissionais, sem incidência de infecção em 160 pacientes acompanhados por duas semanas de pós-operatório.

O outro estudo realizado por Voyles e seus colaboradores (1995) utilizaram um dos componentes do instrumental laparoscópico, trocarter12mm, com o lúmen totalmente preenchido com matéria orgânica (carne para hambúrguer) e alta concentração de micro-organismos-teste (Proteusmirabilis, Enterococcus feacalis, Staphylococcus aureus, S. epidermidis, Actinomyces pyrogenes, Cândida albicans e Escherichia coli na concentração de $1.8 \times 10^{9} \mathrm{UFC} / \mathrm{mL}$ ), para avaliar a eficácia do calor latente e da condução térmica na esterilização a $132^{\circ} \mathrm{C}$, utilizando ciclos convencional e flash, com tempo de exposição de 10 e 3 minutos, respectivamente. Amostras da carne para hambúrguer foram colocadas em placa de Agar sangue, sendo em triplicata para o ciclo convencional (21) e sextoplicata para o ciclo flash (42), todas incubadas em laboratório clínico por 72 horas. Todos os microorganismos-teste foram eliminados. A eficácia da esterilização pelo vapor, nessas condições do experimento, foi atribuída às leis fundamentais da física:

\footnotetext{
... "o contato do vapor com os objetos frios converteu o vapor para o líquido, e ocorreu a fantástica transferência de calor ou energia (cinco vezes a quantidade de energia que seria liberada para resfriar a água de $100^{\circ}$ a $0^{\circ} \mathrm{C}$ ). A transferência de energia, referida como calor latente da vaporização, foi rapidamente transmitida pela condutividade da cânula de metal para as partes internas e efetivamente coagulou as proteínas vegetativas dos micro-organismos, induzindo a morte dos mesmos. A alta pressão atmosférica das autoclaves a vapor aumentou a quantidade de energia (calor) transferindo-a para os instrumentos laparoscópicos durante a condensação. Dentro do pior cenário experimental, houve condução de energia térmica suficiente, apesar das cânulas de metal estarem "fechadas" pelo preenchimento dos lumens com a massa do hambúrguer. Em 3 minutos os organismos patogênicos contaminado foram mortos. A chave da esterilização é o contato do micro-organismo com o calor (energia) e não necessariamente o contato direto com o vapor" (Voyles et al.,1995).
}

Nas mesmas condições de desafio, com o preenchimento do lúmen com matéria orgânica, Voyles e seus colaboradores (1995) também testaram indicadores biológicos comercialmente disponíveis do Geobacillus stearothermophilus ATCC 7953, sendo dez amostras para os seguintes tempos de exposição: 3, 4, 5, 6, 7 e 10 minutos, em temperatura de $132^{\circ} \mathrm{C}$. Simultaneamente, realizaram os mesmos testes sem adição de carne de hambúrguer nos lumens, sendo cinco amostras para cada tempo de exposição. Os indicadores foram incubados a $55^{\circ} \mathrm{C}$ por 48 horas, sendo a 
recuperação microbiana acompanhada diariamente. Dos esporos contidos nos trocartes com lúmen preenchido com matéria orgânica, 100\% (10/10) sobreviveram a 3 e 4 minutos de exposição ao vapor; $60 \%$ (6/10) a 5 minutos, 10\% (1/10) a 6 minutos e nenhum crescimento (0/10) em 7 e 10 minutos de exposição ao vapor. Todos os esporos inseridos nos trocartes sem preenchimento com matéria orgânica, foram destruídos em apenas 3 minutos de exposição ao vapor. A destruição total dos micro-organismos-teste foi alcançada apenas, quando foram usados tempos de esterilização expandidos de 7 e 10 minutos, parâmetros estes distintos dos padronizados para autoclave com pré-vácuo, quais sejam, $132^{\circ} \mathrm{C}$ por 4 minutos (AAMI, 2006; Rutala e Weber, 2008).

A pesquisa de Lopes, Graziano e Pinto (2011) realizada para avaliar a eficácia da esterilidade dos instrumentos laparoscópicos de uso único, empregou como grupo comparativo 50 instrumentos equivalentes reutilizáveis (oito agulha de Veress, 17 aspiradores/irrigadores, 17 aspiradores com eletrocautério e oito pinças). Nos experimentos, após a contaminação desafio com esporos bacterianos (Geobacillus stearothermophilus ATCC 7953) e sangue de carneiro, os instrumentos reutilizáveis foram submetidos a limpeza automatizada em lavadora ultrassônica com retrofluxo com auxílio do detergente enzimático, limpeza manual complementar com serpilhos e irrigação dos lumens com jato de água sob pressão, enxágue com água destilada esterilizada, secagem com ar comprimido medicinal, montagem, acondicionamento em embalagens de papel grau cirúrgico e esterilização a vapor, saturado sob pressão com pré-vácuo à temperatura de $134^{\circ} \mathrm{C}$ por cinco minutos. Os testes de esterilidade foram realizados por inoculação direta dos instrumentos nos meios de cultura de caseína soja e incubação por 20 dias. Não houve recuperação dos micro-organismosteste. Esses resultados reforçam a possibilidade de segurança da esterilização dos materiais montados pelos princípios físicos do calor latente e da condução térmica.

Atualmente, os trabalhos disponíveis sobre a eficácia da esterilização do instrumental cirúrgico autoclavado montado não trazem respostas conclusivas. A pesquisa desenvolvida por Marshburn e seus colaboradores (1991) não eliminou $100 \%$ dos micro-organismos-teste nos materiais montados, mas também não obteve sucesso nos desmontados, o que é preocupante, uma vez que esta última condição é a melhor possível para propiciar a condução térmica. Os trabalhos de Voyles e seus colaboradores (1995) obtiveram sucesso na destruição total dos micro-organismos- 
Tamara Carolina de Camargo

teste no ciclo expandido de 7 a 10 minutos, não preconizado como rotina no CME. Os resultados dos experimentos de Lopes, Graziano e Pinto (2011), embora os objetivos da pesquisa não tenham sido avaliara esterilização em instrumental laparoscópico montado, os resultados do grupo comparativo, composto por instrumentos laparoscópicos montados reutilizáveis, sinalizam para eficácia da autoclavação de instrumental montado. 
3 OBJETIVOS 


\section{OBJETIVOS}

Objetivo Geral: avaliara segurança microbiológica da esterilização a vapor do instrumental laparoscópico previamente montado.

\section{Objetivos Específicos:}

- Avaliar a eficácia de diferentes métodos de limpeza do instrumental laparoscópico reutilizável, em relação à eliminação do resíduo orgânico de proteína, hemoglobina e carboidrato, após contaminação intencional, como um pré-requisito para segurança da esterilização;

- Avaliar a esterilização do instrumental laparoscópico reutilizável previamente montado, após contaminação desafio. 


\section{MATERIAL E MÉTODO}

\subsection{TIPO DE PESQUISA}

Esta pesquisa caracterizou-se como um estudo experimental, laboratorial controlado.

\subsection{LOCAIS DA PESQUISA}

Os locais desta pesquisa foram:

- Laboratório de Ensaios Microbiológicos² (LEM) do Departamento de Enfermagem Médico-Cirúrgica da Escola de Enfermagem da Universidade de São Paulo (EEUSP), onde foram realizadas as etapas de limpeza manual, ultrassônica e extração dos resíduos orgânicos; preparo e esterilização dos meios de cultura; montagem dos instrumentos laparoscópicos com contaminação desafio; testes de esterilidade por meio da incubação, em meio de cultura, dos indicadores biológicos utilizados, como contaminação desafio.

- Centro Obstétrico ${ }^{3}$ e Centro de Material e Esterilização ${ }^{4}$ do Hospital Universitário da Universidade de São Paulo onde foram realizadas, respectivamente, as etapas de contaminação intencional com sangue de placenta humana e a esterilização do instrumental laparoscópico montado.

- Laboratório de Biomateriais ${ }^{5}$ da Faculdade de Ciências Médicas e da Saúde, da Pontifícia Universidade Católica de São Paulo (PUC-SP), campus Sorocaba, onde foram realizados os testes para análise dos resíduos orgânicos de proteínas, carboidratos e hemoglobina por meio de espectrofotometria.

- Laboratório de Microbiologia ${ }^{6}$ da Faculdade de Ciências Médicas da Santa Casa de São Paulo onde os meios de cultura que apresentaram mudanças no aspecto, foram analisados microbiologicamente.

\footnotetext{
${ }^{2}$ Sob responsabilidade da Dra. KazukoUchikawa Graziano.

${ }^{3}$ Sob responsabilidade da enfermeira Chang Yi Wei.

${ }^{4}$ Sob responsabilidade da enfermeira Cristiane de Lion Botero Couto Lopes.

${ }^{5}$ Sob responsabilidade da Dra. Eliana Aparecida de Rezende Duek.

${ }^{6}$ Sob responsabilidade da microbiologista Cely Barreto da Silva.
} 
Tamara Carolina de Camargo

\subsection{AMOSTRA}

Dois tipos de instrumental laparoscópico reutilizável de maior complexidade para a realização do estudo foram selecionados: Trocarte com válvula tipo janela rosqueada, composto por cinco peças, sendo uma delas com lúmen de $5 \mathrm{~mm}$ de diâmetro e Pinça de Dissecção de $5 \mathrm{~mm}$, composta por quatro peças com extremidade denteada e lúmen com comprimento de $30 \mathrm{~cm}$ e diâmetro interno de $3 \mathrm{~mm}$ (Figura 1). O trocarte e a pinça laparoscópica possuem, respectivamente, uma superfície de 81 e $156 \mathrm{~cm}^{2}$ (Anexo 1).

Figura 1 - Instrumental laparoscópico utilizado nos experimentos. São Paulo, 2013.

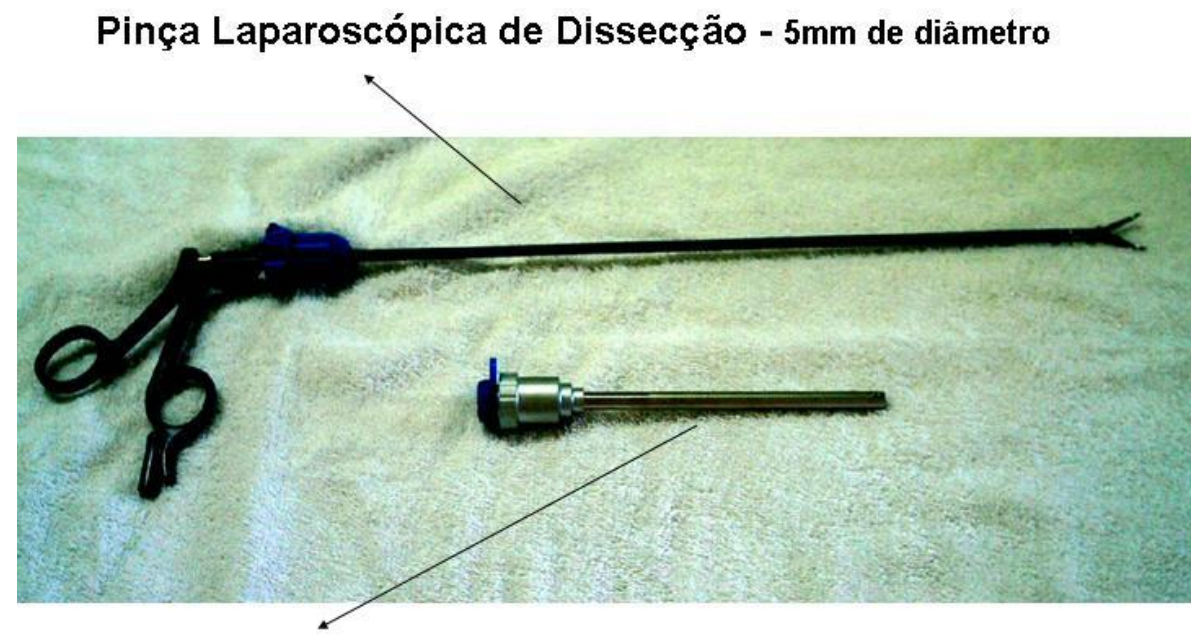

Trocarte com válvula tipo janela rosqueada $-5 \mathrm{~mm}$ de diâmetro

Fonte: Própria do autor.

\subsection{COLETA DE DADOS}

Este estudo foi desenvolvido em duas etapas. A primeira, avaliou a eficácia de diferentes métodos de limpeza do instrumental laparoscópico reutilizável; e a segunda, avaliou a esterilização do instrumental laparoscópico reutilizável montado.

Considerando-se a eficácia da limpeza, pré-requisito fundamental para a garantia do processo de esterilização, foi necessária a avaliação da eficácia da limpeza como ponto de partida. Caso houvesse insucesso na esterilização do instrumental laparoscópico montado, não seria atribuída à ineficácia da limpeza.

A seguir, os procedimentos metodológicos estão detalhados por etapas. 
Tamara Carolina de Camargo

\subsubsection{Avaliação da eficácia de diferentes métodos de limpeza do instrumental laparoscópico}

Contaminação intencional

Para simular o uso do instrumental laparoscópico, este foi contaminado com sangue de placenta humana. Utilizou-se $1 \mathrm{~mL}$ de sangue extraído da veia umbilical da placenta para contaminação das superfícies externas de cada instrumental. Também foi injetado $1 \mathrm{~mL}$ do sangue no lúmen de cada trocarte. $\mathrm{O}$ instrumental foi mantido em contato com sangue por 1 hora à temperatura ambiente.

Figura 2- Contaminação do instrumental laparoscópico com sangue de placenta humana. São Paulo, 2013.

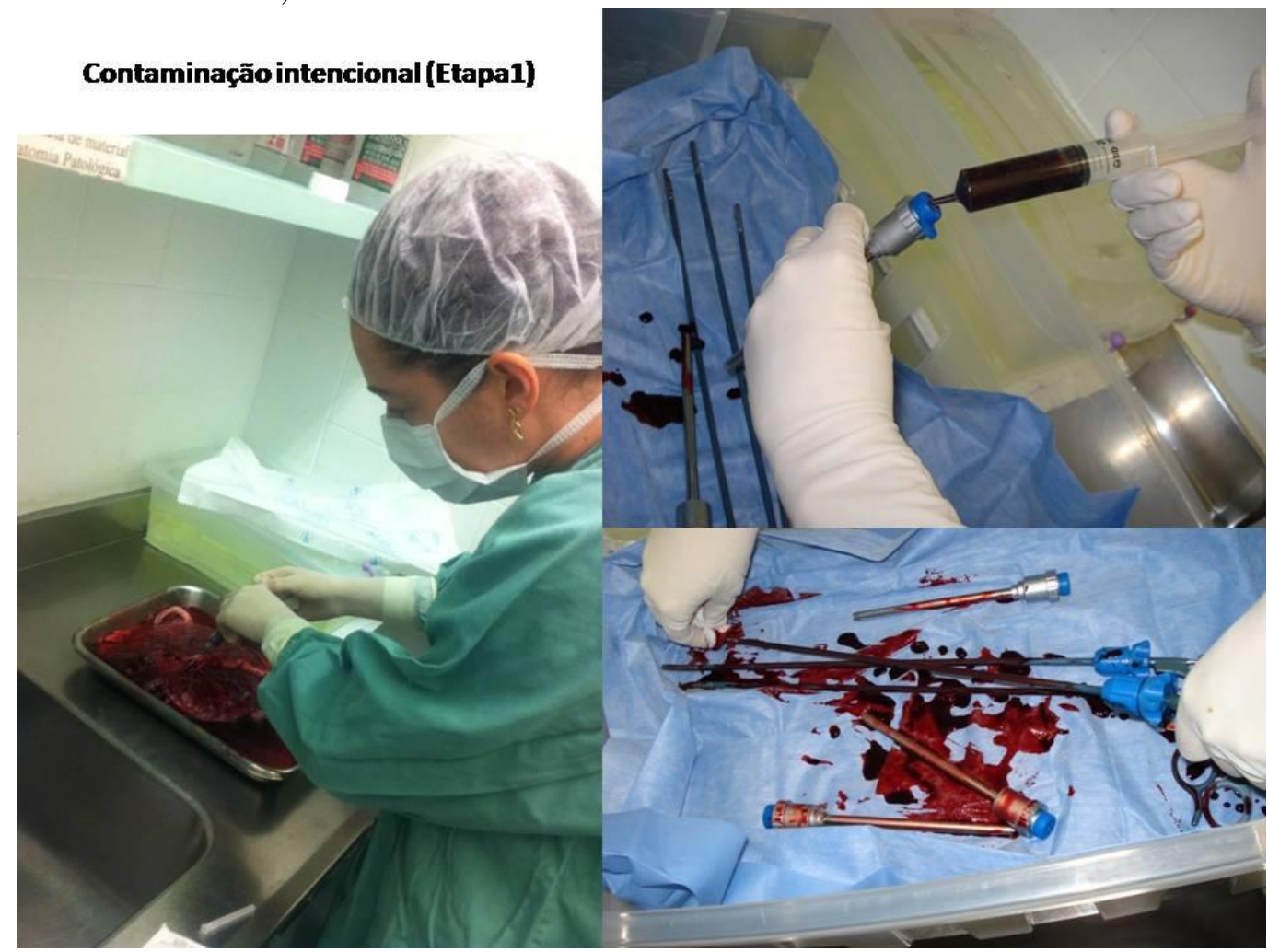

Fonte: Própria do autor.

Limpeza do instrumental laparoscópico:

\section{Limpeza manual}

A limpeza manual foi realizada com instrumental laparoscópico desmontado. Todas as peças foram imersas em água potável por, aproximadamente, 10 minutos, para pré-umectação. Em seguida, foram enxaguadas em água corrente e imersas em 
solução de detergente enzimático ${ }^{7}$, por 2 minutos, seguindo as orientações do fabricante, injetando solução dentro dos lumens com auxílio de seringa. Toda superfície externa foi friccionada com escovas de cerdas macias e firmes, com atenção especial para as reentrâncias, cremalheira, articulações e ranhuras. O lúmen foi lavado com auxílio de escovas descartáveis de 5 e $2 \mathrm{~mm}$ de diâmetro e comprimento de $60 \mathrm{~cm}$ (Instrusponge ${ }^{\circledR}$ ). O instrumental foi enxaguado em água corrente com auxílio de pistola de água sob pressão, direcionada para a estrutura interna das peças (Figura 3).

\section{Limpeza automatizada ultrassônica}

O material é de conformação complexa e com lúmen interno inferior a $5 \mathrm{~mm}$, atendendo às orientações da Agência Nacional de Vigilância Sanitária - ANVISA (Brasil, 2012), a limpeza manual foi complementada pela limpeza automatizada em lavadora ultrassônica específica para materiais canulados, com sistema de bombeamento pulsante retrofluxo (H.Stratnner ${ }^{\circledR}$ com capacidade para 2 quilos de instrumentos, frequência ultrassônica de $35 \mathrm{kHz}, 127$ Volts - 50/60 Hz). Utilizou-se ciclo de 10 minutos a $45^{\circ} \mathrm{C}$, associado à ação de detergente enzimático.

Figura 3 - Processos de limpeza. São Paulo, 2013.

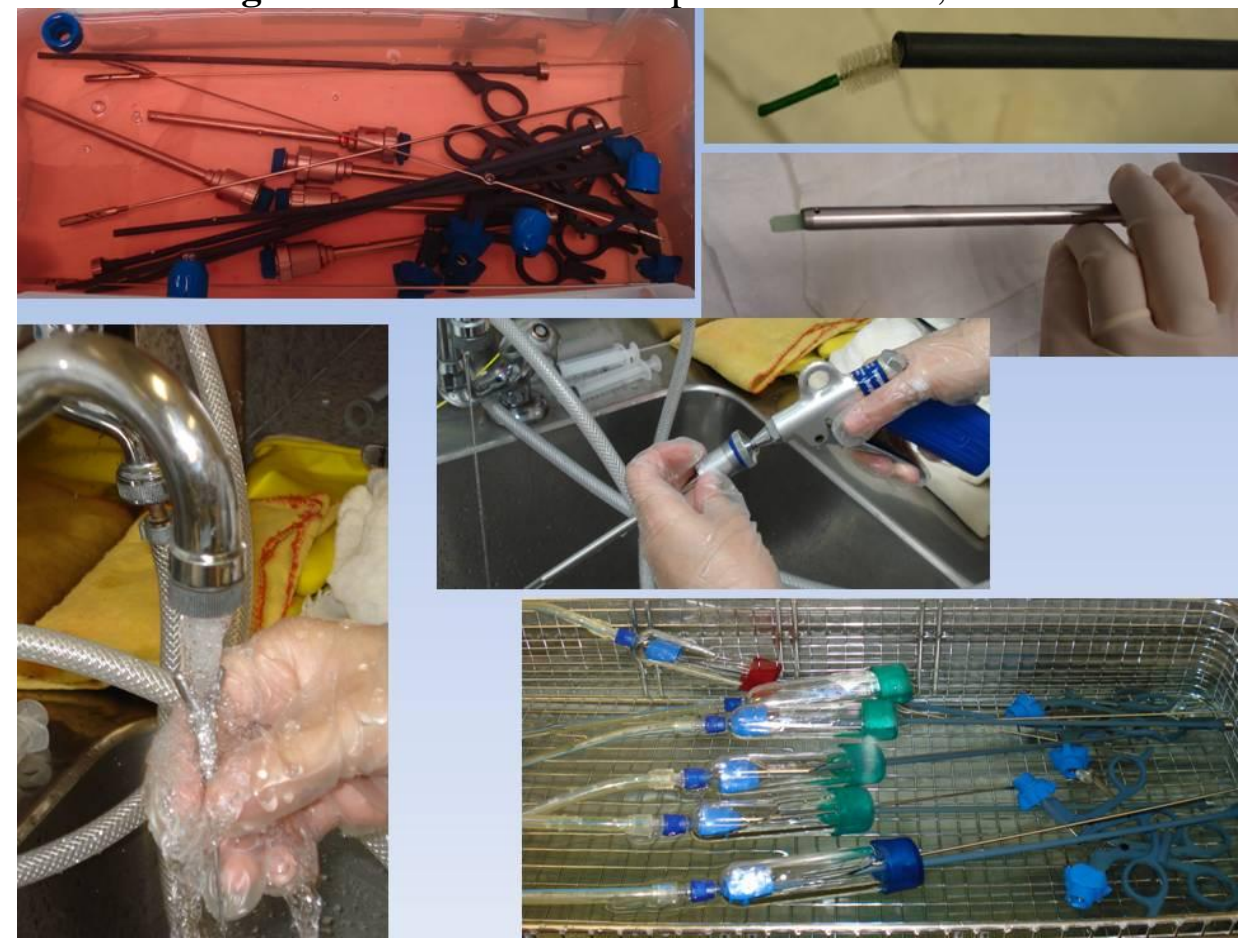

Fonte: Própria do autor.

\footnotetext{
${ }^{7}$ Composição do detergente enzimático: amilase, protease, lipase, carbioidrase, álcool isopropílico e surfactante não iônicos, com pH neutro (Endozime ${ }^{\circledR}$ AW Plus APA - ação proteolítica avança).
} 
Tamara Carolina de Camargo

Para garantir a eficácia da limpeza automatizada, os ciclos da lavadora ultrassônica foram monitorados por meio das tecnologias Sono Check ${ }^{\circledR}$ e Tosi LumChek $^{\circledR}$ (Figura 4).

Figura 4-Testes para avaliação do funcionamento da lavadora ultrassônica. São Paulo, 2013.

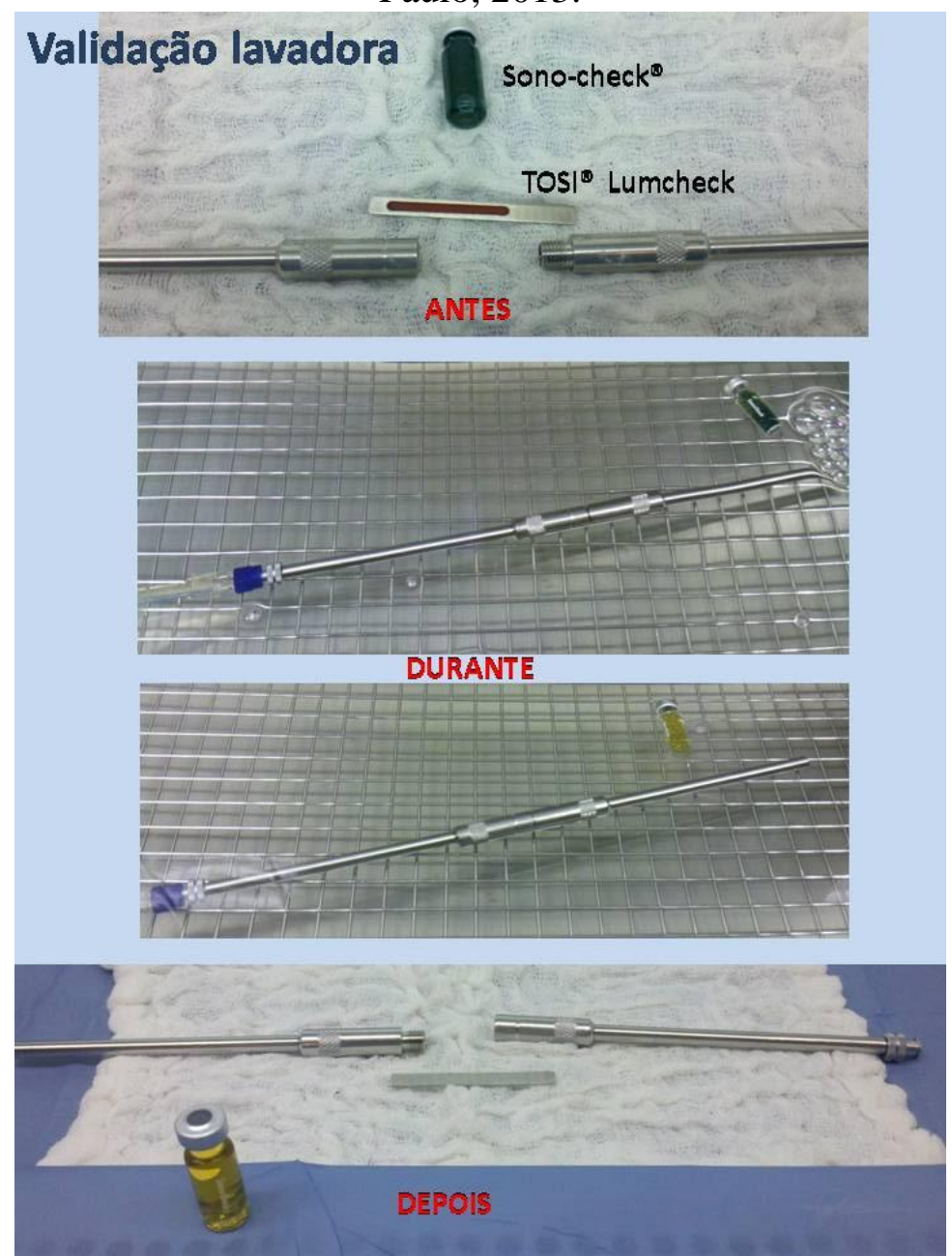

Fonte: Própria do autor.

Após a limpeza automatizada ultrassônica, que não inclui a etapa de enxágue, o instrumental foi manualmente enxaguado em água potável, com auxílio de pistola de água sob pressão direcionada para a estrutura interna das peças. Foi realizado um enxágue final com água destilada esterilizada. Ao término do processo todas as peças do instrumental foram dispostas em posição vertical, sob campo branco por alguns minutos para secagem natural e inspeção quanto à presença de possíveis sujidades residuais. 
Tamara Carolina de Camargo

\section{Grupos de estudo}

Esta etapa foi constituída pelos seguintes grupos de estudo, com os respectivos tamanhos amostrais arbitrados:

- Grupo Experimental: quantificação dos resíduos orgânicos do instrumental laparoscópico submetidos aos procedimentos de contaminação intencional e aplicação consecutiva de diferentes métodos de limpeza implementados em CMEs:

(1) limpeza manual com enxágue em água potável (amostra: cinco pinças laparoscópicas e cinco trocartes);

(2) limpeza manual com enxágue em água potável, seguida de limpeza ultrassônica sem enxágue (amostra: cinco pinças laparoscópicas e cinco trocartes). A lavadora ultrassônica não possui enxágue automatizado em seu ciclo. Embora seja imprescindível o enxágue manual, é possível admitir a omissão desta etapa nas práticas dos CMEs, o que justificou esta análise;

(3) limpeza manual com enxágue em água potável, seguida de limpeza ultrassônica com enxágue em água potável (amostra: cinco pinças laparoscópicas e cinco trocartes);

(4) limpeza manual com enxágue em água potável, seguida de limpeza ultrassônica com enxágue em água potável e último enxágue em água destilada esterilizada (amostra: três pinças laparoscópicas e três trocartes).Este método de limpeza foi considerado o gold standard.O grupo experimental foi constituído por uma amostra total de 36 instrumentos, sendo 18 pinças laparoscópicas e 18 trocartes.

- Controle Positivo (Baseline): quantificação dos resíduos orgânicos do instrumental laparoscópico submetidos aos procedimentos de contaminação intencional. A amostra foi composta por três pinças laparoscópicas e três trocartes, ambos contaminados em três placentas distintas, totalizando 18 instrumentos, sendo nove pinças laparoscópicas e nove trocartes.

- Controle Negativo: quantificação dos resíduos orgânicos do instrumental laparoscópico novo, submetidos à:

(1) limpeza manual e enxágue em água potável (amostra: três pinças laparoscópicas e três trocartes).

(2) limpeza manual, limpeza ultrassônica, enxágue em água potável complementado por enxágue final com água destilada esterilizada (amostra: três pinças 
laparoscópicas e três trocartes). O grupo Controle Negativo totalizou uma amostra 12 instrumentos, sendo seis pinças laparoscópicas e seis trocartes.

A Figura 5 apresenta de forma esquemática os grupos de estudo, os métodos de limpeza testados, bem como os testes indiretos realizados.

Figura 5 - Esquema dos diferentes métodos testados para limpeza do instrumental laparoscópico. São Paulo, 2013.

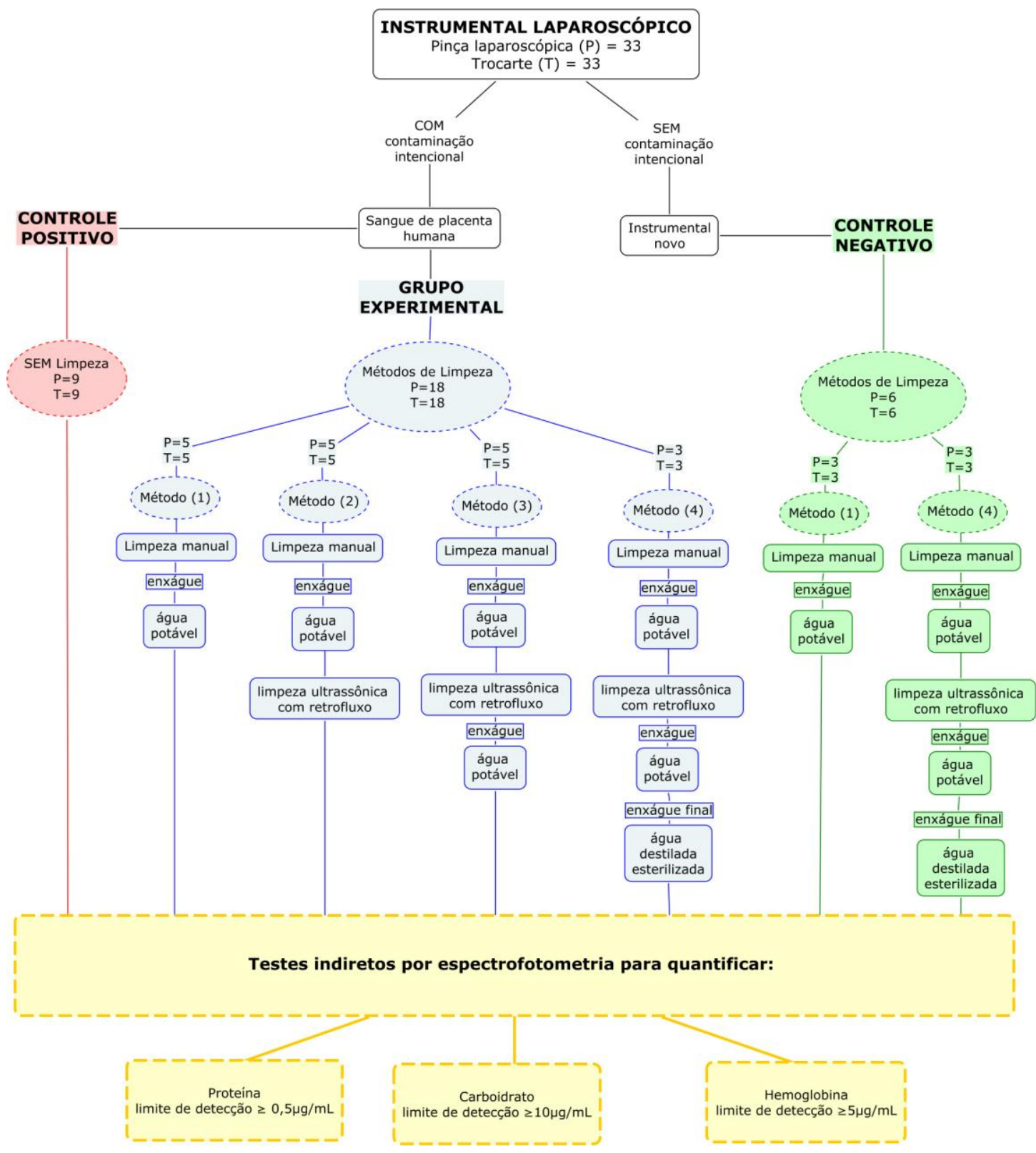

Fonte: Própria do autor. 
Tamara Carolina de Camargo

\section{Métodos para avaliação dos resíduos orgânicos}

\section{Método de extração}

Sob técnica asséptica, cada instrumental a ser submetido à análise dos resíduos orgânicos foi individualmente colocado no interior de um saco plástico esterilizado, adicionando-se $250 \mathrm{~mL}$ de água destilada esterilizada e lacrado. Em seguida, foram expostos a três sessões de sonicação (sonicador modelo USC-2800, Enge Solutions ${ }^{\circledR}$ ) com duração de 10 segundos cada e agitados (agitador modelo 255-B, Fanem ${ }^{\circledR}$ ) com movimento orbital por 10 minutos a 160rpm, para desprendimento dos resíduos orgânicos (Figura 6).

Figura 6- Procedimentos para extração dos resíduos orgânicos. São Paulo, 2013.

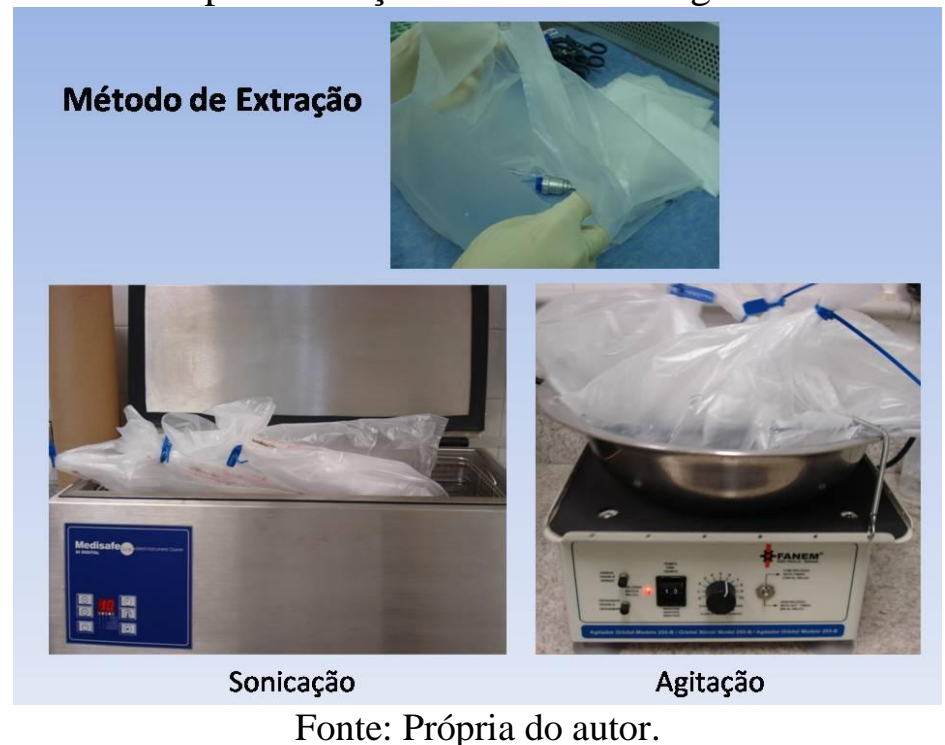

\section{Análise dos resíduos orgânicos}

No interior da cabine de proteção biológica (modelo VLFS, VECO ${ }^{\circledR}$ com filtro HEPA), foram aspirados $50 \mathrm{~mL}$ da solução de extração, acondicionando em tubo cônico e em uma amostra de $1 \mathrm{~mL}$ foram realizados testes indiretos para detecção de resíduos orgânicos (proteína, carboidrato e hemoglobina). Os valores obtidos na análise de $1 \mathrm{~mL}$ foram multiplicados por 250 para estimar o valor total do resíduo orgânico presente no instrumental. Utilizou-se a técnica de espectrofotometria (espectrofotômetro Biotek ${ }^{\circledR}$, modelo ELx800) para comparar a radiação absorvida pela solução que continha quantidade desconhecida dos resíduos dosados, parametrizados com a quantidade conhecida das mesmas substâncias. Para determinar a concentração da solução desconhecida foi construído inicialmente um 
gráfico da variação de absorbância em função da concentração das soluções-padrão: protein standard solution, D+ glucose anidra e hemoglobina humana liofilizada $\left(\right.$ Sigma $\left.^{\circledR}\right)$.

A quantificação da proteína foi realizada pelo teste indireto, utilizando o kit de ensaio Quanti Probicinchoninic acid/BCA (Sigma ${ }^{\circledR}$ QPBCA), indicado para detectar baixas concentrações de proteínas em pequenos volumes de soluções, dando uma resposta linear de 0,5 a $30 \mu \mathrm{g} / \mathrm{mL}$ de proteína. Este kit de ensaio é constituído por:

- QuantiPro Buffer QA (M3810). O reagente de QA é fornecido em recipiente, contendo $250 \mathrm{~mL}$ de uma solução que consistede carbonato de sódio, sódiotartatee bicarbonato de sódioem $0,2 \mathrm{M} \mathrm{NaOH}(0,8$ gramas de hidróxido de sódio em 100mL de água), pH 11.25.

- QuantiPro Buffer QB (M3685). O reagente QB é fornecido emrecipiente contendo $250 \mathrm{~mL}$ de uma solução de ácido bicinchoninic $4 \%(\mathrm{w} / \mathrm{v}), \mathrm{pH} 8.5$.

- Copper (II) Sulfate pentahydrate 4\% solution QC (C 2284). O reagente QC é fornecido em recipiente contendo $12 \mathrm{~mL}$ de $4 \%(\mathrm{w} / \mathrm{v})$ de sulfatode cobre (II), solução penta-hidratado.

- Protein Standard Solution - Bovine serum albumin/BSA (P0914). Este produto é fornecido em 10 ampolas de vidro, cada uma contendo1,0mL de uma solução de $1,0 \mathrm{mg} / \mathrm{mL}$ de soro de albumina bovina em $0,15 \mathrm{M} \mathrm{NaCl}$ com $0,05 \%$ de azida de sódio, como conservante.

O Reagente de Trabalho QuantiPro é preparado pela mistura de 25 partes de reagente de QA com 25 partes de reagente QB. Depois que os reagentes QA e QB foram combinados, adicionou-se 1 parte de Reagente QC (sulfato de cobre (II) e foi misturado até obter uma cor uniforme levemente esverdeada.

Para cada $100 \mu \mathrm{L}$ da solução a ser analisada, foram adicionados $100 \mu \mathrm{L}$ do Reagente de Trabalho QuantiPro, agitando levemente a microplaca, sendo incubada a $60^{\circ} \mathrm{C}$ por 1 hora e submetida à leitura no espectrofotômetro regulado a 570nm (Figura 7). O limite de detecção foi igual ou maior que $0,5 \mu \mathrm{g} / \mathrm{mL}$. 
Figura 7 - Testes indiretos para detecção dos resíduos orgânicos, com leitura por espectrofotometria. São Paulo, 2013.

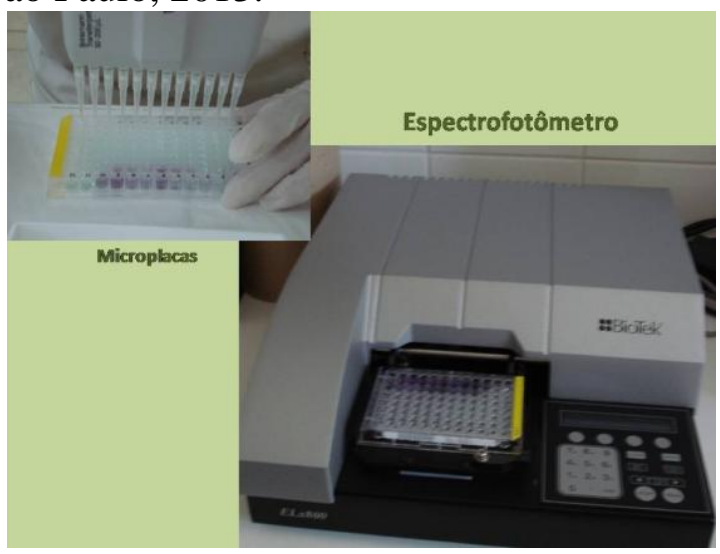

Fonte: Própria do autor.

Inicialmente, foi constituída uma curva-padrão adicionando a solução Protein Standard Solution (Bovine serum albumin/BSA) à água Mili-Q, nas proporções, conforme os dados da Tabela 1, mantendo-se um volume total de 1000 $\mu \mathrm{L}$ (Gráfico $1)$.

Tabela 1 - Proporções utilizadas para construção da curva-padrão de proteínas. São Paulo, 2013.

\begin{tabular}{|l|c|c|c|c|}
\hline tubo & $\begin{array}{c}\text { Volume de BSA } \\
(\mu \mathrm{L})\end{array}$ & $\begin{array}{c}\text { Volume de água } \\
\text { Mili-Q }(\mu \mathrm{L})\end{array}$ & $\begin{array}{c}\text { Total de proteína em } \\
1.000(\mu \mathrm{g})\end{array}$ & $\begin{array}{c}\text { Concentração total } \\
\text { de proteína } \\
(\mu \mathrm{g} / \mathrm{mL})\end{array}$ \\
\hline 1 & 30 & 970 & 30 & 30 \\
\hline 2 & 20 & 980 & 20 & 20 \\
\hline 3 & 10 & 990 & 10 & 10 \\
\hline 4 & 5 & 995 & 5 & 0,5 \\
\hline 5 & 0,5 & 999,5 & 0,5 & 0 \\
\hline 6 & 0 & 1.000 & 0 & \\
\hline
\end{tabular}

Gráfico 1 - Curva-padrão de proteínas. São Paulo, 2013. Curva padrão de Proteínas

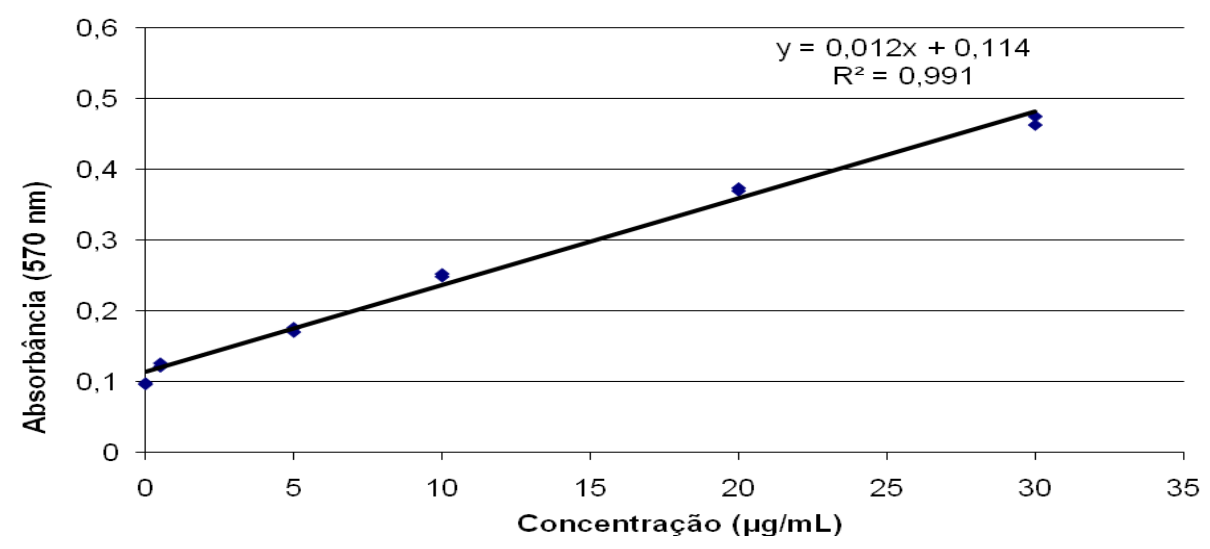


Tamara Carolina de Camargo

A quantificação do resíduo de carboidrato foi por meio do teste indireto, baseado na técnica bioquímica proposta por Liu et al. (1994); para cada $250 \mu \mathrm{L}$ da solução analisada, foram adicionados $50 \mu \mathrm{L}$ de Fenol 5\% agitando imediatamente em Vortex (digital Vortex-Genie 2, modelo SI-A236, Scientific Industries ${ }^{\circledR}$ ). Posteriormente, adicionou-se $1 \mathrm{~mL}$ de Ácido Sulfúrico 95\%-98\% agitando imediatamente em Vortex. A seguir, $200 \mu \mathrm{L}$ do conteúdo de cada tubo foram transferidos para uma microplaca deixada à temperatura ambiente por 30 minutos e submetida à leitura no espectrofotômetro regulado a 490nm (Figura 6). O limite de detecção do método foi igual ou maior que $10 \mu \mathrm{g} / \mathrm{mL}$.

Inicialmente, foi constituída uma curva-padrão adicionando uma solução de glicose (D+ glucose anidra, Sigma ${ }^{\circledR}$ G7021) à água Mili-Q, nas proporções, conforme os dados da Tabela 2, mantendo-se um volume total de 250 $\mu \mathrm{L}$ (Gráfico 2).

Tabela 2: Proporções utilizadas para construção da curva-padrão de carboidratos. São Paulo, 2013.

\begin{tabular}{|c|c|c|c|c|}
\hline Tubo & $\begin{array}{c}\text { Volume de } \\
\text { glucose } \\
(\mu \mathrm{L})\end{array}$ & $\begin{array}{c}\text { Volume de } \\
\text { água Mili-Q } \\
(\mu \mathrm{L})\end{array}$ & $\begin{array}{c}\text { Total de } \\
\text { carboidrato em } \\
250 \mu \mathrm{L}(\mu \mathrm{g})\end{array}$ & $\begin{array}{c}\text { Concentração de } \\
\text { carboidrato } \\
(\mu \mathrm{g} / \mathrm{mL})\end{array}$ \\
\hline 1 & 200 & 50 & 200 & 800 \\
\hline 2 & 100 & 150 & 100 & 400 \\
\hline 3 & 50 & 200 & 50 & 200 \\
\hline 4 & 25 & 225 & 25 & 100 \\
\hline 5 & 12,5 & 237,5 & 12,5 & 50 \\
\hline 6 & 6,25 & 243,75 & 6,25 & 25 \\
\hline 7 & 2,5 & 247,5 & 2,5 & 10 \\
\hline 8 & 0 & 250 & 0 & 0 \\
\hline
\end{tabular}

Gráfico 2 - Curva-padrão de carboidratos. São Paulo, 2013. Curva padrão de Carboidratos

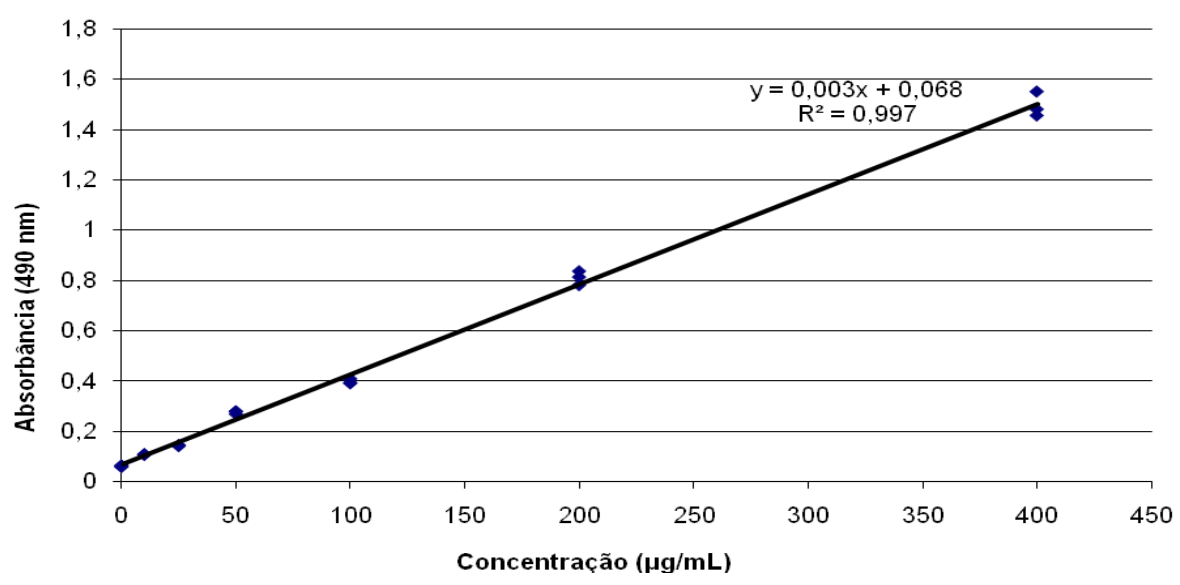


Para detecção de hemoglobina, utilizou-se o reagente TMB One (Solução de tetrametil benzidina, G7431, Promega ${ }^{\circledR}$ ). Para cada $50 \mu \mathrm{L}$ da solução a ser analisada, foram adicionados $150 \mu \mathrm{L}$ do reagente TMB One, agitando levemente a microplaca, sendo incubada a $37^{\circ} \mathrm{C}$ por 30 minutos e na sequência submetida à leitura no espectrofotômetro regulado a $650 \mathrm{~nm}$. O limite de detecção foi igual ou maior que $5 \mu \mathrm{g} / \mathrm{mL}$.

Inicialmente, foi constituída uma curva-padrão adicionando-se uma solução de hemoglobina humana liofilizada (Promega ${ }^{\circledR}$ H7379) à água Mili-Q, nas proporções conforme os dados da Tabela 3, mantendo-se um volume total de $400 \mu \mathrm{L}$ (Gráfico 3).

Tabela 3: Proporções utilizadas para construção da curva-padrão de hemoglobina. São Paulo, 2013.

\begin{tabular}{|c|c|c|c|c|}
\hline tubo & $\begin{array}{c}\text { Volume } \\
\text { hemoglobina padrão } \\
-1000 \mu \mathrm{g} / \mathrm{mL}- \\
(\mu \mathrm{L})\end{array}$ & $\begin{array}{c}\text { Volume de } \\
\text { água Mili- } \\
\mathrm{Q} \\
(\mu \mathrm{L})\end{array}$ & $\begin{array}{c}\text { Total de } \\
\text { hemoglobina } \\
\text { em } 400 \mu \mathrm{L} \\
(\mu \mathrm{g})\end{array}$ & $\begin{array}{c}\text { Concentração total de } \\
\text { hemoglobina } \\
(\mu \mathrm{g} / \mathrm{mL})\end{array}$ \\
\hline 1 & 60 & 340 & 60 & 150 \\
\hline 2 & 40 & 360 & 40 & 100 \\
\hline 3 & 20 & 380 & 20 & 50 \\
\hline 4 & 8 & 392 & 8 & 20 \\
\hline 5 & 4 & 396 & 4 & 5 \\
\hline 6 & 2 & 398 & 2 & 0 \\
\hline 7 & 0 & 400 & 0 & \\
\hline
\end{tabular}

Gráfico 3 - Curva-padrão de hemoglobina. São Paulo, 2013.

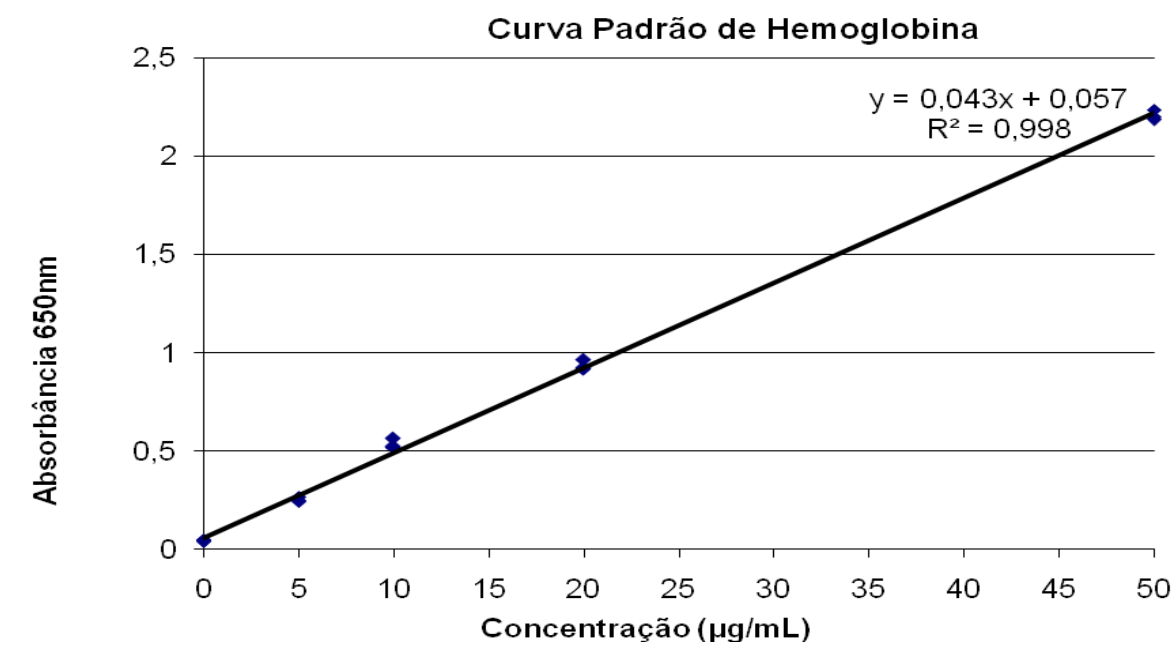


Tamara Carolina de Camargo

\subsubsection{Avaliação da esterilização do instrumental laparoscópico montado}

Contaminação desafio

Elegeu-se como micro-organismo desafio os esporos do Geobacillus stearothermophillus ATCC 7953, extraídos do indicador biológico comercialmente disponível para monitoramento dos ciclos de autoclavação (Indicador biológico Attest $^{\mathrm{TM} \circledast}$, referência 1.262, 48horas, vapor).

O indicador biológico do tipo autocontido, é composto por um suporte de papel (dimensões $2,5 \times 0,5 \mathrm{~cm}$ ), contendo uma população microbiana mínima de 100.000 (cem mil) esporos secos e calibrados de Geobacillus stearothermophillus ATCC 7953, para controle biológico dos processos de esterilização a vapor saturado. O suporte de papel contendo esporos está acondicionado em um pequeno tubo plástico, que também acondiciona uma ampola de vidro, contendo um caldo nutriente próprio para o cultivo do micro-organismo-teste e indicador colorimétrico para mudança de $\mathrm{pH}$ do meio. $\mathrm{O}$ tubete plástico é fechado por uma tampa perfurada e protegida por um papel de filtro hidrofóbico. Cada tubete possui um rótulo externo que informa o lote e a data de fabricação do produto, contendo campos para identificação do tubete e um indicador químico externo que diferencia os tubetes processados dos não processados (Figura 8).

Figura 8: Indicador biológico comercialmente disponível para monitoramento dos ciclos de autoclavação. São Paulo, 2013.

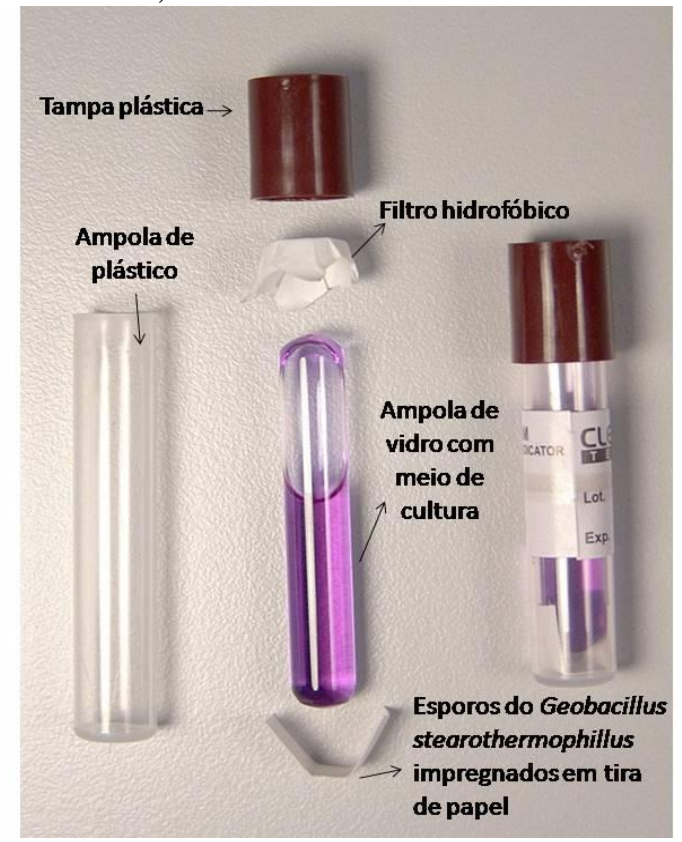

Fonte: Própria do autor. 
Tamara Carolina de Camargo

A escolha deste micro-organismo justificou-se por ser este padronizado, como monitor biológico no controle da eficácia dos ciclos de autoclavações, pela sua resistência ao calor úmido e pelo seu baixo potencial patogênico em condições normais (Pinto, Kaneko e Ohara, 2010).

\section{Preparo e esterilização do instrumental laparoscópico}

Com técnica asséptica, os tubetes do indicador biológico foram desmontados, reservando os suportes de papel impregnados com esporos Geobacillus stearothermophillus ATCC 7953 (Figura 9).

Figura 9 - Indicadores biológicos sendo desmontados para retirada dos suportes de papel impregnados com esporos Geobacillus stearothermophillus ATCC 7953. São Paulo, 2013.

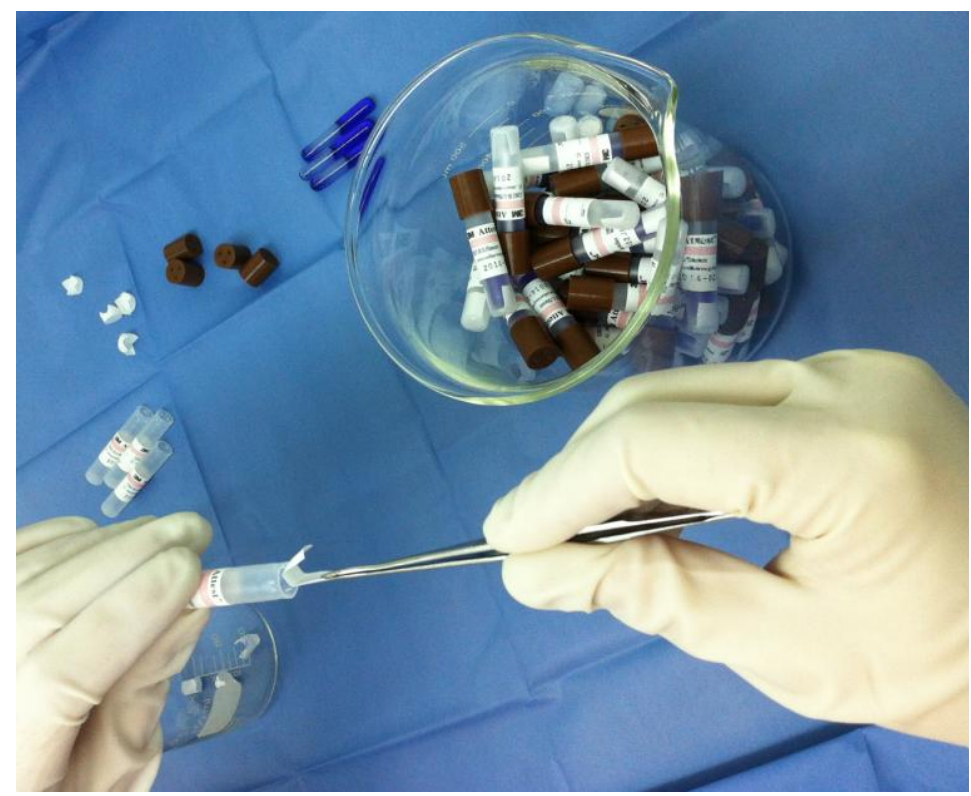

Fonte: Própria do autor.

Foram colocadas três unidades de suporte de papel impregnadas com esporos Geobacillus stearothermophillus ATCC 7953, extraídas do indicador biológico, no interior de cada instrumento laparoscópico, previamente limpo por limpeza manual com enxágue em água potável, seguida de limpeza ultrassônica com enxágue em água potável e último enxágue em água destilada esterilizada. 
Figura 10 - Disposição dos indicadores biológicos nas pinças laparoscópicas. São Paulo, 2013.

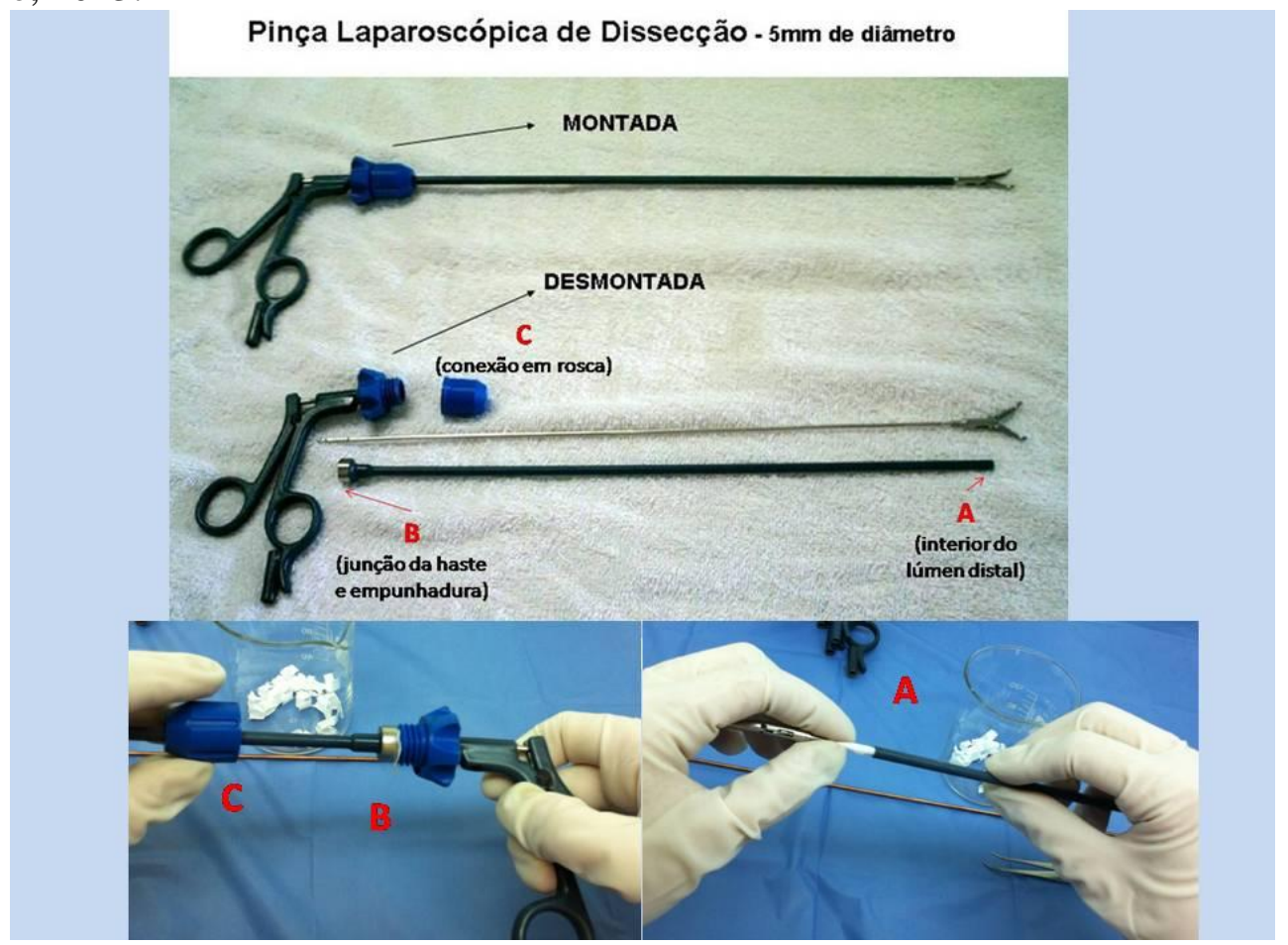

Fonte: Própria do autor.

Figura 11 - Disposição dos indicadores biológicos nos trocartes. São Paulo, 2013.

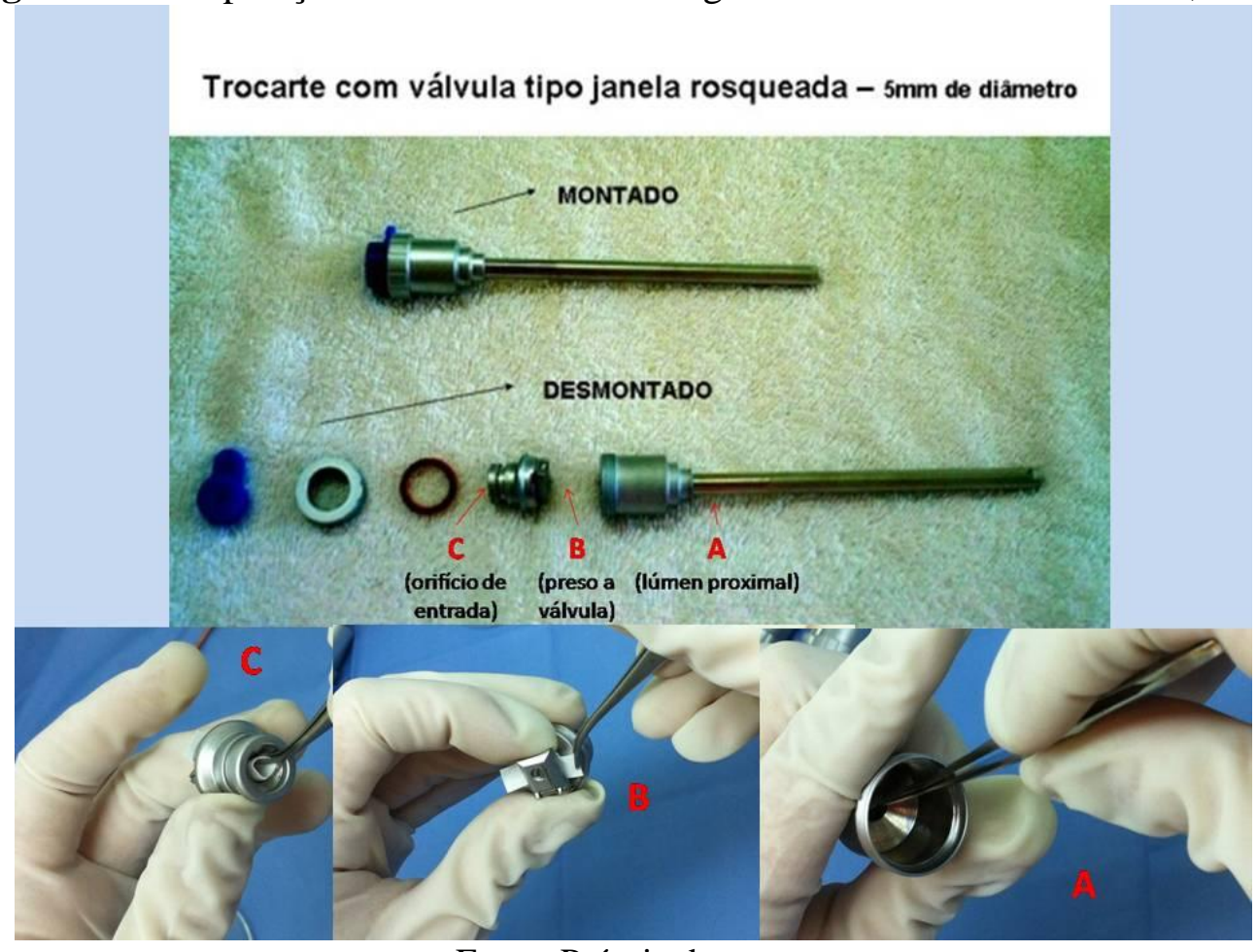

Fonte: Própria do autor.

Cada instrumento foi individualmente embalado em papel grau cirúrgico, selado com seladora térmica e submetido à esterilização. 
A esterilização foi realizada no Centro de Material e Esterilização do Hospital Universitário, por meio de autoclave a vapor saturado sob pressão com pré-vácuo, marca Cisa ${ }^{\circledR}$, modelo 6412HF, com capacidade 558 litros, microprocessada, termicamente qualificada, conforme a Norma ISO/NBR 17.665-1/2010 (ABNT, 2010), para a esterilização de instrumental cirúrgico à temperatura de $134^{\circ} \mathrm{C}$ por 5 minutos, no período entre 24/11/12 e 09/12/12 (Anexo 2).

\section{Meios de Cultura}

Foram preparados meios TSB, a partir do meio desidratado $\left(\mathrm{BD}^{\circledR}\right.$ referência 211825, lote $n^{\circ}$ 0319.126, validade 30/09/15), obedecendo à recomendação do fabricante, utilizando água purificada (destilada, deionizada e desmineralizada).

Os meios dispensados em tubos, em um volume de $5 \mathrm{~mL}$ foram esterilizados em autoclave a vapor saturado sob pressão, marca Tuttnauer ${ }^{\circledR}$, modelo 3850ELVC, com capacidade 62 litros, microprocessada, termicamente qualificada, conforme a Norma ISO/NBR 17.665-1/2010 (ABNT, 2010), no ciclo esterilização de meio de cultura a $121^{\circ} \mathrm{C}$ por 20 minutos, no período entre 12/11/12 e 01/12/12 (Anexo 3).

Seguindo as orientações do Instituto Nacional de Controle de Qualidade em Saúde (INCQS) da Fundação Oswaldo Cruz (FIOCRUZ), foi realizado o controle de esterilização dos meios de cultura, por meio da incubação de 5\% do total de tubos preparados a $36^{\circ} \mathrm{C}$, durante 7 dias (Brasil, 2009). Não houve crescimento microbiológico em nenhuma das amostras (Apêndice A).

\section{$\underline{\text { Incubação }}$}

Após a esterilização, no interior da cabine de proteção biológica e utilizando técnica asséptica, cada instrumental foi desmontado e cada suporte de papel do indicador biológico foi semeado no meio de cultura TSB. Cada tubo foi identificado com o número do instrumental-teste e sua respectiva posição no instrumental (A, B e C). Seguindo o método para avaliação da atividade esporocida proposto pelo INCQS (Brasil, 2009), os tubos foram incubados a $56^{\circ} \mathrm{C}$ por 21 dias (Figura 12). 
Tamara Carolina de Camargo

Figura 12 - Incubação dos meios de cultura. São Paulo, 2013.

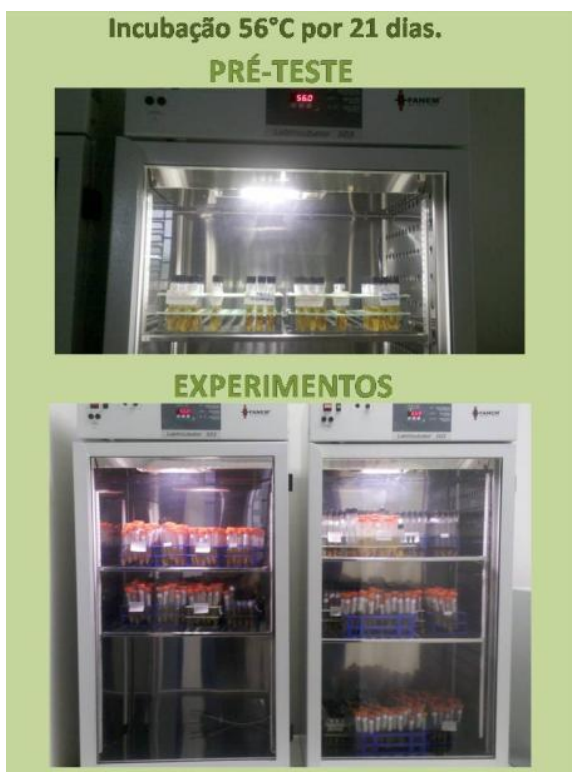

Fonte: Própria do autor.

Não foi observado crescimento após este período, todos os tubos foram submetidos a um choque térmico, durante 20 minutos a $80^{\circ} \mathrm{C}$ (Figura 13), com reincubação por mais 72 horas a $56^{\circ} \mathrm{C}$ para leitura final (Brasil, 2009). Este último procedimento recomendado pelo INCQS objetivou estimular a germinação dos esporos, eventualmente, sobreviventes ao processo de autoclavação.

Figura 13 - Choque térmico dos meios de cultura. São Paulo, 2013.

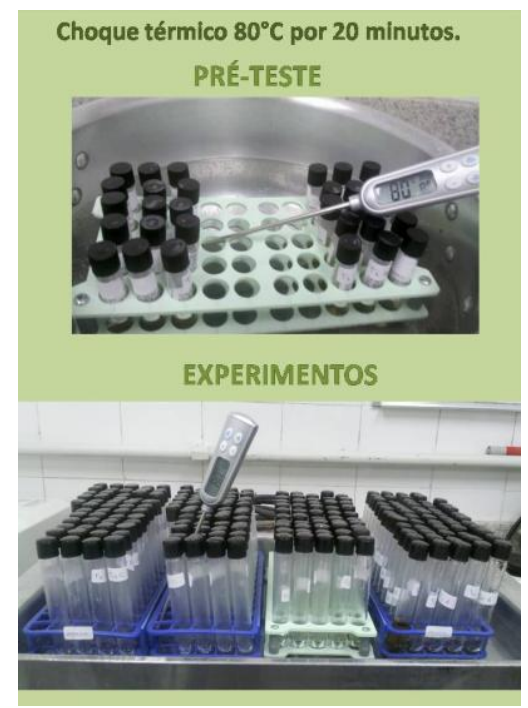

Fonte: Própria do autor. 
Para as leituras que suscitassem dúvidas, foram previstas bacterioscopias e provas bioquímicas, de modo a diferenciar o micro-organismo-teste de uma eventual contaminação acidental.

\section{$\underline{\text { Grupos de estudo }}$}

Com a finalidade de subsidiar o cálculo do tamanho amostral e também a exequibilidade técnica dos experimentos, foi realizado um pré-teste constituído pelos seguintes grupos de estudo, com os respectivos tamanhos amostrais arbitrados:

- Grupo Experimental: inoculação de três suportes de papel do indicador biológico introduzidos, durante a montagem de cada uma das cinco pinças laparoscópicas (posição A, B e C) e dos cinco trocartes (posição A, B e C), esterilizados montados.

- Controle Positivo: inoculação de três suportes de papel filtro removidos com técnica asséptica do indicador biológico e semeados diretamente em TSB a $56^{\circ} \mathrm{C}$ por 48 horas.

- Controle Negativo: inoculação de três suportes de papel do indicador biológico introduzidos em cada uma das cinco pinças laparoscópicas (posição A, B e C) e dos cinco trocartes (posição A, B e C), esterilizados desmontados.

Mediante os resultados satisfatórios dos pré-testes, foi consultado um profissional estatístico ${ }^{8}$ para cálculo do tamanho amostral dos experimentos. Para ganhar poder para o teste, foi assumido que, de fato, a esterilização do instrumental laparoscópico desmontado (Grupo Controle Negativo) promove a eliminação total dos esporos. Partindo-se dessa premissa, foi decidido realizar apenas a coleta de dados do grupo instrumental montado (Grupo Experimental), cuja expectativa era apresentar $100 \%$ de eliminação dos micro-organismos-teste.

Para atender ao cálculo do tamanho amostral, foram adquiridos 36 instrumentos laparoscópicos, sendo 18 pinças laparoscópicas e 18 trocartes. Considerando o número máximo de 10 repetições para os ensaios, foi possível avaliar 180 pinças laparoscópicas e 180 trocartes montados com contaminação desafio. O Controle Positivo foi realizado em cada repetição do ensaio, totalizando 30 amostras.

\footnotetext{
${ }^{8}$ Lucas Petri Damiani (CONRE: 9442-A).
} 
Chow, Shao e Wang (2008) listam tipos de cálculo de tamanho amostral. O mais comum, intitulado de tamanho amostral de estimação/determinação, é baseado em testes de hipótese, a fim de encontrar o tamanho mínimo que garanta o nível de significância e poder pré-estabelecidos (geralmente, 5\% e 80\%, respectivamente). Mas, o presente caso enquadrou-se em outro tipo de cálculo amostral, intitulado de tamanho amostral explicado (sample size justification), que nada mais é do que explicar o porquê dos 183. E, nesse caso, foi sugerida uma avaliação do nível de significância e poder dos determinados testes.

Para isso, foram definidas como hipóteses:

$$
\left\{\begin{array}{l}
H_{0^{*}}: p=0 \\
H_{A^{a}}: p>0
\end{array}\right.
$$

Onde p é a probabilidade do instrumental laparoscópico montado (pinças ou trocartes) apresentar germinação dos esporos, após a esterilização. Definiu-se como estatística de teste $T(\boldsymbol{x})=\Sigma x_{i}$, este teste propõe que, se alguma amostra for positiva, se rejeita a hipótese de que a esterilização do instrumental laparoscópico montado é tão segura como a esterilização do instrumental laparoscópico desmontado.

Com o teste definido, pode-se estimar o erro do tipo I e a função do poder (um menos a probabilidade do erro do tipo 2). O erro do tipo I foi dado por:

$$
\alpha=P\left(\text { rejeitar } H_{0} \mid H_{0} \text { verdadeiro }\right) \text {. }
$$

Ressalta-se que se $H_{0}$ é verdadeiro, então, $p=0$ e, consequentemente, $\alpha=P(T(x) \geq 1 \| p=0)=0$, que significa que o teste não está sujeito ao erro de tipo I.Isto faz sentido, uma vez que se encontrar esporo viável após a esterilização, então, não tem como errar na hipótese de que a probabilidade de acontecer seja positiva.

Portanto, só resta controlar o erro do tipo II ou o poder do teste, que uma função da probabilidade alternativa, definida por:

$$
\begin{gathered}
f\left(p_{A}\right)=P\left(\text { rejeitar } H_{0} \mid H_{0} \text { falso }\right)= \\
P\left(T(X) \geq 1 \mid p=p_{A}\right)
\end{gathered}
$$

Nesse caso, pode-se dizer que $T(\boldsymbol{X}) \sim \operatorname{Binomial}\left(n, p_{A}\right)$. E, portanto,

$$
f\left(p_{A}\right)=1-P\left(T(X)=0 \mid p=p_{A}\right)=1-\left(\begin{array}{l}
n \\
0
\end{array}\right) p_{A}{ }^{0}\left(1-p_{A}\right)^{n}=1-\left(1-p_{A}\right)^{n}
$$

O Gráfico 4 ilustra o valor da função poder para um intervalo de valores de $e_{p_{A}}$. Dado $\mathrm{n}=183$ garante-se com poder $95 \%$, a probabilidade do instrumental laparoscópico montado (pinças ou trocartes) apresentar germinação dos esporos, após a esterilização de, pelo menos, $8 \%$. 
Tamara Carolina de Camargo

Gráfico 4 - Poder do teste para o tamanho amostral dos experimentos de avaliação da esterilização do instrumental laparoscópico montado. São Paulo, 2013.

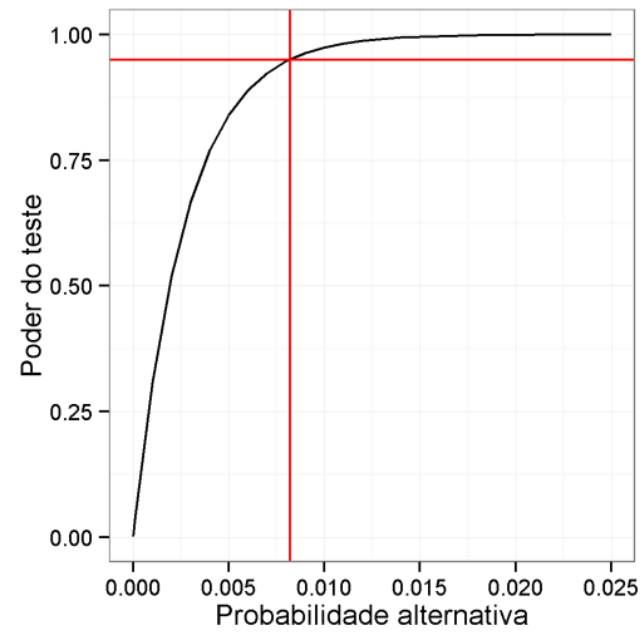




\section{ReSUltados}




\section{RESULTADOS}

Nos experimentos da Etapa 1, que consistiu na avaliação da eficácia dos diferentes métodos de limpeza do instrumental laparoscópico na remoção de resíduos orgânicos de proteína, carboidrato e hemoglobina, foram analisados 66 instrumentos laparoscópicos, sendo 33 pinças e 33 trocartes.

A contaminação intencional com sangue de placenta humana evidenciou altas concentrações, com grande variabilidade dos níveis dos resíduos orgânicos de proteína (média de $183 \mu \mathrm{g} / \mathrm{cm}^{2} /$ pinça e $482 \mu \mathrm{g} / \mathrm{cm}^{2} /$ trocarte), carboidrato (média de $18 \mu \mathrm{g} / \mathrm{cm}^{2} /$ pinça e $42 \mu \mathrm{g} / \mathrm{cm}^{2} /$ trocarte) e hemoglobina (média de $219 \mu \mathrm{g} / \mathrm{cm}^{2} /$ pinça e $615 \mu \mathrm{g} / \mathrm{cm}^{2} /$ trocarte), conforme esperado, caracterizando o grupo Controle Positivo.

Para o grupo Controle Negativo, foram quantificados os resíduos orgânicos no instrumental laparoscópico novo, sem contaminação intencional, sendo uma parte da amostra submetida aos procedimentos de limpeza manual e enxágue em água potável, e a outra submetida à limpeza manual e enxágüe em água potável, seguida da limpeza ultrassônica, enxágue em água potável complementado por enxágue final com água destilada esterilizada. Para este grupo, os níveis máximos médios de proteína foram $1,70 \mu \mathrm{g} / \mathrm{cm}^{2}$ e de carboidrato de $1,07 \mu \mathrm{g} / \mathrm{cm}^{2}$, não sendo detectada hemoglobina. Não houve diferença estatística entre os métodos de limpeza (1) e (4), no grupo Controle Negativo.

O grupo experimental avaliou os resíduos orgânicos das pinças laparoscópicas e dos trocartes intencionalmente contaminados com sangue de placenta, após a aplicação consecutiva dos diversos métodos de limpeza: (1) limpeza manual com enxágue em água potável; (2) limpeza manual com enxágue em água potável, seguida de limpeza ultrassônica sem enxágue; (3) limpeza manual com enxágue em água potável, seguida de limpeza ultrassônica com enxágue em água potável e (4) limpeza manual com enxágue em água potável, seguida de limpeza ultrassônica com enxágue em água potável e último enxágue em água destilada esterilizada.

Os dados da Tabela 4 apresentam a distribuição dos valores mínimo, máximo, mediana, média e desvio-padrão dos resíduos de carboidrato, proteína e hemoglobina em $\mu \mathrm{g} / \mathrm{cm}^{2}$ e em $\mu \mathrm{g} /$ pinça laparoscópica dos grupos de estudo, e os dados da Tabela 5 apresentam os valores correspondentes para os trocartes. O resultado da avaliação individual de cada instrumento encontra-se no Apêndice B. 
Tabela 4 - Distribuição dos valores mínimo, máximo, mediana, média e desviopadrão dos resíduos de carboidrato, proteína e hemoglobina em $\mu \mathrm{g} / \mathrm{cm}^{2}$ e em $\mu \mathrm{g} /$ pinça laparoscópica. São Paulo, 2013.

\begin{tabular}{|c|c|c|c|c|c|c|c|}
\hline \multirow[b]{2}{*}{ Grupos de Estudo } & \multirow[b]{2}{*}{$\mathbf{n}$} & \multicolumn{2}{|c|}{ PROTEÍNA } & \multicolumn{2}{|c|}{ CARBOIDRATO } & \multicolumn{2}{|c|}{ HEMOGLOBINA } \\
\hline & & $\mu \mathrm{g} / \mathrm{cm}^{2}$ & $\mu \mathrm{g} /$ pinça & $\mu \mathrm{g} / \mathrm{cm}^{2}$ & $\mu \mathrm{g} /$ pinça & $\mu \mathrm{g} / \mathrm{cm}^{2}$ & $\mu \mathrm{g} /$ pinça \\
\hline Controle positivo & 9 & & & & & & \\
\hline Intervalo & & 46-393 & 7171-61297 & $0-48$ & $768-7536$ & $51-424$ & $8029-66186$ \\
\hline Mediana & & 170,55 & 26.606 & 9,84 & 1535 & 221,22 & 34.510 \\
\hline Média & & 183,07 & 28558 & 17,89 & 2791 & 218,97 & 34.159 \\
\hline Desvio-padrão & & 116,55 & 18182 & 16,53 & 2578 & 134,82 & 21.032 \\
\hline $\begin{array}{l}\text { (1) Limpeza manual + enxágue } \\
\text { em água potável }\end{array}$ & 5 & & & & & & \\
\hline Intervalo & & $0-2,31$ & $0-361$ & $0-1,34$ & $0-209$ & $0-0,30$ & $0-46$ \\
\hline Mediana & & 0,13 & 21 & 0,00 & 0 & 0,11 & 17 \\
\hline Média & & 0,57 & 89 & 0,36 & 56 & 0,10 & 16 \\
\hline Desvio-padrão & & 0,99 & 154 & 0,58 & 91 & 0,12 & 19 \\
\hline $\begin{array}{l}\text { (2) Limpeza manual + USS }{ }^{*} \text {, s/ } \\
\text { enxágue }\end{array}$ & 5 & & & & & & \\
\hline Intervalo & & $0-0,82$ & $0-127$ & $0-4,47$ & $0-698$ & $0-0,04$ & $0-6$ \\
\hline Mediana & & 0,00 & 0 & 0,45 & 70 & 0,00 & 0 \\
\hline Média & & 0,24 & 38 & 1,25 & 195 & 0,01 & 1 \\
\hline Desvio-padrão & & 0,36 & 57 & 1,88 & 294 & 0,02 & 3 \\
\hline $\begin{array}{l}\text { (3) Limpeza manual + USS, c/ } \\
\text { enxágue em água potável }\end{array}$ & 5 & & & & & & \\
\hline Intervalo & & $0-1,50$ & $0-233$ & $0-1,34$ & $0-209$ & $0-0$ & $0-0$ \\
\hline Mediana & & 0,54 & 85 & 0,00 & 0 & 0,00 & 0 \\
\hline Média & & 0,65 & 102 & 0,45 & 70 & 0,00 & 0 \\
\hline Desvio-padrão & & 0,55 & 86 & 0,63 & 99 & 0,00 & 0 \\
\hline
\end{tabular}

(4) Limpeza manual + USS, c/ enxágue em água potável + enxágue final em água destilada esterilizada 3

$\begin{array}{rrrrrrr}\text { Intervalo } & 0-0,14 & 0-21 & 0-0,45 & 0-70 & 0-0,04 & 0-6 \\ \text { Mediana } & 0,00 & 0 & 0,00 & 0 & 0,00 & 0 \\ \text { Média } & 0,04 & 7 & 0,15 & 23 & 0,01 & 2 \\ \text { io-padrão } & 0,08 & 12 & 0,26 & 40 & 0,02 & 3\end{array}$

Controle negativo

(1) limpeza manual + enxágue em água potável

\section{3}

$\begin{array}{rrrrrrr}\text { Intervalo } & 0-0,14 & 0-22 & 0-0,90 & 0-140 & 0-0 & 0-0 \\ \text { Mediana } & 0,12 & 18 & 0,00 & 0 & 0,00 & 0 \\ \text { Média } & 0,08 & 13 & 0,30 & 47 & 0,00 & 0 \\ & 0,08 & 12 & 0,52 & 81 & 0,00 & 0\end{array}$

Controle negativo

(4) limpeza manual + USS, c/ enxágue em água potável e água destilada esterilizada

$\begin{array}{rrrrrrr}\text { Intervalo } & 0-0 & 0-0 & 0-1,07 & 0-167 & 0-0 & 0-0 \\ \text { Mediana } & 0,00 & 0 & 0,00 & 0 & 0,00 & 0 \\ \text { Média } & 0,00 & 0 & 0,36 & 56 & 0,00 & 0 \\ \text { Desvio-padrão } & 0,00 & 0 & 0,62 & 96 & 0,00 & 0\end{array}$

Observações: "USS - limpeza com lavadora ultrassônica específica para materiais canulados, com sistema de bombeamento pulsante retrofluxo. Considerou-se como 0 resultados menores que o limite detecção para o teste, não significando necessariamente ausência. 
Tabela 5 - Distribuição dos valores mínimo, máximo, mediana, média e desviopadrão dos resíduos de carboidrato, proteína e hemoglobina em $\mu \mathrm{g} / \mathrm{cm}^{2}$ e em $\mu \mathrm{g} /$ trocarte. São Paulo, 2013.

\begin{tabular}{|c|c|c|c|c|c|c|}
\hline \multirow[b]{2}{*}{ Grupos de Estudo } & \multicolumn{2}{|c|}{ PROTEÍNA } & \multicolumn{2}{|c|}{ CARBOIDRATO } & \multicolumn{2}{|c|}{ HEMOGLOBINA } \\
\hline & $\mathbf{n} \mu \mathrm{g} / \mathrm{cm}^{2}$ & $\mu \mathrm{g} /$ trocarte & $\mu \mathrm{g} / \mathrm{cm}^{2}$ & $\mu \mathrm{g} /$ trocarte & $\mu \mathrm{g} / \mathrm{cm}^{2}$ & $\mu \mathrm{g} /$ trocarte \\
\hline Controle positivo & 9 & & & & & 1701- \\
\hline Intervalo & $54-1282$ & $4413-103816$ & $0-117$ & $70-9490$ & $21-1588$ & 128656 \\
\hline Mediana & 320,36 & 25.949 & 18,09 & 1.465 & 506,04 & 40.989 \\
\hline Média & 482,55 & 39087 & 42,31 & 3427 & 615,05 & 49.819 \\
\hline Desvio-padrão & 420,93 & 34095 & 44,96 & 3641 & 575,04 & 46.578 \\
\hline \multicolumn{7}{|l|}{ (1) Limpeza manual } \\
\hline +enxágue em água potável & 5 & & & & & \\
\hline Intervalo & $0-1,31$ & $0-106$ & $0-6,03$ & $0-488$ & $0-0$ & $0-0$ \\
\hline Mediana & 0,26 & 21 & 0,86 & 70 & 0,00 & 0 \\
\hline Média & 0,42 & 34 & 2,07 & 167 & 0,00 & 0 \\
\hline Desvio-padrão & 0,54 & 44 & 2,40 & 195 & 0,00 & 0 \\
\hline \multicolumn{7}{|l|}{$\begin{array}{l}\text { (2) Limpeza manual + USs } \\
\text { s/ enxágue }\end{array}$} \\
\hline Intervalo & $0-0,79$ & $0-64$ & $0-0$ & $0-0$ & $0-0$ & $0-0$ \\
\hline Mediana & 0,00 & 0 & 0,00 & 0 & 0,00 & 0 \\
\hline Média & 0,16 & 13 & 0,00 & 0 & 0,00 & 0 \\
\hline Desvio-padrão & 0,36 & 29 & 0,00 & 0 & 0,00 & 0 \\
\hline \multicolumn{7}{|l|}{$\begin{array}{l}\text { (3) Limpeza manual + USS, } \\
\text { c/ enxágue em água } \\
\text { potável }\end{array}$} \\
\hline Intervalo & $0-0$ & $0-0$ & $0-2,58$ & $0-209$ & $0-0$ & $0-0$ \\
\hline Mediana & 0,00 & 0 & 0,00 & 0 & 0,00 & 0 \\
\hline Média & 0,00 & 0 & 0,69 & 56 & 0,00 & 0 \\
\hline Desvio-padrão & 0,00 & 0 & 1,12 & 91 & 0,00 & 0 \\
\hline
\end{tabular}

(4) Limpeza manual + USS,

c/ enxágue em água

potável + enxágue final em

água destilada esterilizada 3

\begin{tabular}{rrccccc} 
Intervalo & $0-2,36$ & $0-191$ & $0-0$ & $0-0$ & $0-0$ & $0-0$ \\
Mediana & 0,00 & 0 & 0,00 & 0 & 0,00 & 0 \\
Média & 0,79 & 64 & 0,00 & 0 & 0,00 & 0 \\
Desvio-padrão & 1,36 & 110 & 0,00 & 0 & 0,00 & 0 \\
\hline
\end{tabular}

Controle Negativo (1)

limpeza manual + enxágue

em água potável

\section{3}

\begin{tabular}{rrrrrrr} 
Intervalo & $0-0$ & $0-0$ & $0-0$ & $0-0$ & $0-0$ & $0-0$ \\
Mediana & 0,00 & 0 & 0,00 & 0 & 0,00 & 0 \\
Média & 0,00 & 0 & 0,00 & 0 & 0,00 & 0 \\
Desvio-padrão & 0,00 & 0 & 0,00 & 0 & 0,00 & 0 \\
\hline
\end{tabular}

Controle negativo (4)

limpeza manual + USS, c/

enxágue em água potável e

água destilada esterilizada 3

$\begin{array}{rrrrrrr}\text { Intervalo } & 0-1,70 & 0-138 & 0-0 & 0-0 & 0-0 & 0-0 \\ \text { Mediana } & 0,32 & 26 & 0,00 & 0 & 0,00 & 0 \\ \text { Média } & 0,68 & 55 & 0,00 & 0 & 0,00 & 0 \\ \text { Desvio-padrão } & 0,90 & 73 & 0,00 & 0 & 0,00 & 0\end{array}$

Observações: "USS - limpeza com lavadora ultrassônica espećfica para materiais canulados, com sistema de bombeamento pulsante retrofluxo. Considerou-se como 0 resultados menores que o limite deteç̧ão para o teste, não significando necessariamente ausência. 
Em todos os métodos empregados para limpeza do instrumental laparoscópico, obteve-se uma redução dos resíduos orgânicos avaliados quando comparados com os valores dos resíduos do grupo controle positivo (Tabela 6). Entretanto, na comparação entre os diferentes métodos testados para a limpeza utilizando a estatística inferencial, o teste não paramétrico de Kruskal-Walis não detectou diferença nas comparações múltiplas entre os métodos.

Em outras palavras, o teste estatístico não foi capaz de detectar diferença, sem afirmar equivalentes, entre submeter os instrumentos, apenas a limpeza manual ou complementada com limpeza automatizada em lavadora ultrassônica destinada a materiais canulados, com sistema de bombeamento pulsante com retrofluxo, assim como o enxágue realizado somente com água potável ou complementada com água destilada esterilizada ou mesmo com a supressão do enxágue (valor p>0,05).

Tabela 6 - Redução percentual média dos resíduos orgânicos de proteína, carboidrato e hemoglobina no instrumental laparoscópico, após diferentes métodos de limpeza empregados. São Paulo, 2013.

\begin{tabular}{|c|c|c|c|c|c|}
\hline \multirow[b]{2}{*}{ Tipo } & \multirow[b]{2}{*}{ Grupos } & \multirow[b]{2}{*}{$\mathbf{N}$} & \multicolumn{3}{|c|}{ Resíduos orgânicos dosados } \\
\hline & & & $\begin{array}{c}\text { Proteína } \\
\mu \mathrm{g} / \text { instrumental (DP) }\end{array}$ & $\begin{array}{c}\text { Carboidrato } \\
\mu \mathrm{g} / \text { instrumental (DP) }\end{array}$ & $\begin{array}{c}\text { Hemoglobina } \\
\mu \mathrm{g} / \text { instrumental (DP) }\end{array}$ \\
\hline \multirow{6}{*}{ Pinça } & Controle positivo & 9 & $28.588(18.182)$ & $2.791(2.578)$ & $34.158(21.031)$ \\
\hline & Métodos de limpeza & \multicolumn{4}{|c|}{ Redução comparadaao controle positivo, após diferentes métodos de limpeza: $(\%)^{*}(\mathrm{DP})$} \\
\hline & (1) Manual & 5 & $99,7(0,5)$ & $98,0(3,3)$ & $100,0(0,1)$ \\
\hline & $\begin{array}{l}\text { (2) Manual }+U S^{* *} \mathrm{~s} / \\
\text { enxágue }\end{array}$ & 5 & $99,9(0,2)$ & $93,0(10,5)$ & $100,0(0,0)$ \\
\hline & & 5 & $99,6(0,3)$ & $97,5(3,5)$ & $100,0(0,0)$ \\
\hline & $\begin{array}{l}\text { (4) Manual + USS , c/ } \\
\text { enxágue + água destilada }\end{array}$ & 3 & $100,0(0,0)$ & $99,2(1,4)$ & $100,0(0,0)$ \\
\hline \multirow{6}{*}{ Trocarte } & Controle positivo & 9 & $39.086(34.095)$ & $3.426(3.641)$ & $49.818(46.578)$ \\
\hline & Métodos de limpeza & \multicolumn{4}{|c|}{ Redução comparadaao controle positivo, após diferentes métodos de limpeza: $(\%)^{*}(\mathrm{DP})$} \\
\hline & (1) Manual & 5 & $99,9(0,1)$ & $95,1(5,7)$ & $100,0(0,0)$ \\
\hline & $\begin{array}{l}\text { (2) Manual + USS, s/ } \\
\text { enxágue }\end{array}$ & 5 & $100,0(0,1)$ & $100,0(0,0)$ & $100,0(0,0)$ \\
\hline & $\begin{array}{l}\text { (3) Manual + USS, c/ } \\
\text { enxágue }\end{array}$ & 5 & $100,0(0,0)$ & $98,4(2,7)$ & $100,0(0,0)$ \\
\hline & $\begin{array}{l}\text { (4) Manual + USS, c/ } \\
\text { enxágue + água destilada }\end{array}$ & 3 & $99,8(0,3)$ & $100,0(0,0)$ & $100,0(0,0)$ \\
\hline
\end{tabular}

Observações: ${ }^{*} p<0,001 .{ }^{* *}$ USS - limpeza com lavadora ultrassônica específica para materiais canulados, com sistema de bombeamento pulsante retrofluxo. .

Na Etapa 2 de avaliação da esterilização do instrumental laparoscópico montado, foi inicialmente realizado um pré-teste cujos resultados estão sintetizados nos dados da Tabela 7 e apresentados na íntegra no Apêndice C. 
Tamara Carolina de Camargo

Tabela 7 - Resultado do pré-teste para avaliar a esterilização do instrumental laparoscópico montado. São Paulo, 2013.

\begin{tabular}{|c|c|c|c|c|}
\hline \multirow[t]{2}{*}{ Grupos de Estudo } & \multirow[t]{2}{*}{ Tipo instrumental } & \multicolumn{2}{|c|}{ Posição } & \multirow{2}{*}{$\begin{array}{c}\text { Culturas } \\
+/ \text { total }\end{array}$} \\
\hline & & $\mathrm{n}$ & & \\
\hline Controle Positivo & & 3 & & $3 / 3$ \\
\hline \multirow[t]{6}{*}{ Grupo Experimental } & Pinça laparoscópica & 5 & A & $-/ 5$ \\
\hline & & & B & $-/ 5$ \\
\hline & & & $\mathrm{C}$ & $-/ 5$ \\
\hline & Trocarte & 5 & A & $-/ 5$ \\
\hline & & & B & $-/ 5$ \\
\hline & & & $\mathrm{C}$ & $-/ 5$ \\
\hline \multirow[t]{6}{*}{ Controle Negativo } & Pinça laparoscópica & 5 & A & $-/ 5$ \\
\hline & & & B & $-/ 5$ \\
\hline & & & $\mathrm{C}$ & $-/ 5$ \\
\hline & Trocarte & 5 & A & $-/ 5$ \\
\hline & & & B & $-/ 5$ \\
\hline & & & $\mathrm{C}$ & $-/ 5$ \\
\hline
\end{tabular}

Com base nos resultados do pré-teste, o tamanho amostral para os experimentos foi calculado. Foram analisados 360 instrumentos laparoscópicos montados, sendo 180 pinças e 180trocartes. Em cada instrumento, foram inseridos três suportes de papel contaminados com $10^{6}$ UFC do Geobacillus stearothermophillus ATCC 7953, totalizando 1.080 unidades amostrais.

Na leitura dos resultados, os tubos com coloração alterada do meio, porém sem turvação, mesmo que a priori tenha sido atribuída a exposição do meio de cultura à alta temperatura de $56^{\circ} \mathrm{C}$ por 21 dias de incubação, foram submetidos à análise microbiológica do Laboratório de Microbiologia da Faculdade de Ciências Médicas da Santa Casa de São Paulo ${ }^{9}$, que confirmou a ausência de crescimento microbiano em todas as amostras analisadas.

Os dados da Tabela 8 apresentam os resultados consolidados dos experimentos da Etapa 2. Os controles positivos acusaram crescimento satisfatório, demonstrando a viabilidade do meio de cultura e as condições de incubação apropriadas para germinação dos esporos (Figura 14). O resultado da avaliação individual de cada instrumento encontra-se no Apêndice D.

\footnotetext{
${ }^{9}$ Cely Barreto da Silva.
} 
Tamara Carolina de Camargo

Tabela 8 - Resultado das culturas do suporte de papel do indicador biológico, dentro do instrumental laparoscópico esterilizado montado. São Paulo, 2013.

\begin{tabular}{lrcc}
\hline \multicolumn{1}{c}{ Grupos de Estudo } & $\mathrm{N}$ & $\begin{array}{c}\text { Posição } \\
\text { IB }\end{array}$ & $\begin{array}{c}\text { Culturas } \\
+/ \text { total }\end{array}$ \\
\hline Controle Positivo & 30 & & $30 / 30$ \\
Pinça laparoscópica & 180 & $\mathrm{~A}$ & $-/ 180$ \\
& & $\mathrm{~B}$ & $-/ 180$ \\
Trocarte & & $\mathrm{C}$ & $-/ 180$ \\
& 180 & $\mathrm{~A}$ & $-/ 180$ \\
& & $\mathrm{~B}$ & $-/ 180$ \\
& & $\mathrm{C}$ & $-/ 180$ \\
\hline
\end{tabular}

Figura 14 - Leitura final dos experimentos. São Paulo, 2013.

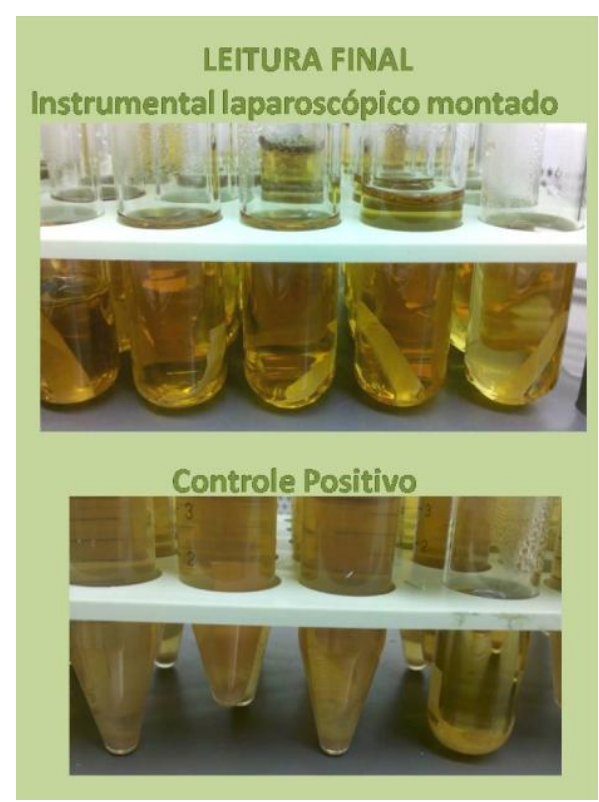

Fonte: Própria do autor. 
6 DisCUSSÃO 


\section{DISCUSSÃO}

O presente estudo experimental laboratorial controlado demonstrou sucesso na esterilização do instrumental laparoscópico montado, comprovando a segurança microbiológica desta prática. Os resultados trazem fortes evidências à enfermagem do CME, para subsidiar a tomada de decisão quanto ao preparo do material laparoscópico.

Os experimentos utilizaram parâmetros padronizados para autoclave a vapor saturado sob pressão com pré-vácuo, temperatura $134^{\circ} \mathrm{C}$ por 5 minutos, associados à contaminação desafio com esporos do Geobacillus stearothermophilus ATCC 7953 na concentração de três vezes $10^{6}$ UFC.O desafio empregado corresponde aos indicadores biológicos utilizados rotineiramente nos CMEs, para controle da efetividade da esterilização. A ausência de crescimento indica que o processo esterilizante usado foi eficaz sobre os micro-organismos.

Estes resultados foram divergentes dos obtidos por Camargo (2007), por ocasião do desenvolvimento de sua dissertação de mestrado respondendo à mesma questão de pesquisa. Quanto à contaminação desafio, em 2007, Camargo utilizou o método de imersão do instrumental laparoscópico em uma suspensão de Geobacillus stearothermophilus na densidade de $10^{6} \mathrm{UFC} / \mathrm{mL}$ acrescidos $10 \%$ do volume de sangue de carneiro, procedendo à limpeza manual e ultrassônica, antes da montagem e esterilização do instrumental laparoscópico. Nos experimentos da presente tese, utilizou-se o modelo do indicador biológico, e em cada instrumento laparoscópico foram inseridas, como contaminação desafio, três unidades contaminantes de esporulado de Geobacillus stearothermophilus ATCC 7953, $10^{6}$ UFC/suporte.

A amostra de Camargo (2007) compôs-se de 24 instrumentos laparoscópicos montados, procedendo à semeadura individual das peças dos instrumentos diretamente em TSB, sendo 12 pinças (total de 48 peças ao serem desmontadas) e 12 trocartes (total de 60 peças ao serem desmontadas), totalizando 108 unidades amostrais. Nesta tese, foram analisados 370 instrumentos laparoscópicos montados, sendo 185 pinças e 185 trocartes, com culturas de três suportes extraídos de indicadores biológicos por instrumentos, totalizando 1.110 unidades amostrais.

Os testes de esterilidade de Camargo (2007) foram feitos por um laboratório terceirizado, que procedeu a desmontagem do instrumental esterilizado montado e a inoculação direta das diversas peças do instrumental, de conformação e tamanhos 
diferentes. No doutorado, a pesquisadora assumiu todas as etapas dos testes de esterilidade, inoculando diretamente em meio de cultura os suportes de papel de dimensões $2,5 \times 0,5 \mathrm{~cm}$, impregnados com micro-organismo-teste, removidos do instrumental laparoscópico esterilizado, montado após a autoclavação.

Nas condições do experimento de Camargo em 2007, houve contaminação em três peças de uma mesma pinça (3/48) e em três peças de um mesmo trocarte (3/60). Na atual investigação, não houve crescimento em nenhuma das 1.110 unidades amostrais.

Os crescimentos positivos encontrados nos experimentos de Camargo, em 2007, não foram explorados, quanto ao gênero e espécie dos responsáveis pela turvação do meio de cultura, mas, sim, pelos aspectos morfológicos. Caso fosse detectada a presença de outros micro-organismos, que não o empregado como desafio, poderia ser considerada contaminação acidental ocorrida durante a realização dos experimentos. Somente a confirmação da presença do microorganismo-teste, naquelas contaminações, refutaria a hipótese de segurança microbiológica da esterilização do instrumental laparoscópico montado.

Conforme explicado na introdução deste trabalho, estes resultados divergentes deverão compor a amostra de uma futura revisão sistemática com metanálise.

A autoclavação do instrumental laparoscópico montado é uma realidade nas instituições de saúde brasileiras (Feitosa, Camargo e Graziano, 2011), contrariando as recomendações clássicas que orientam que os instrumentos cirúrgicos estejam abertos, desmontados e com as superfícies livres para a esterilização (Committee on Infection Control in the Handling of Endoscopic Equipment - Guidelines for preparation of laparoscopic instrumentation, 1980; AAMI, 2006; Rutala e Weber 2008; Padoveze, Quelhas e Nakamura, 2010). O resultado da presente investigação trouxe forte evidência científica quanto à segurança microbiológica da esterilização do instrumental laparoscópico montado, subsidiando esta prática das instituições de saúde brasileiras. O CME disponibiliza o instrumental laparoscópico previamente montado, assim, facilita e agiliza sobremaneira o início do procedimento cirúrgico.

Destaca-se que os resultados satisfatórios foram obtidos com o uso de autoclave a vapor saturado sob pressão com pré-vácuo termicamente qualificada conforme a Norma ISO/NBR 17.665-1/2010 (ABNT, 2010), para a esterilização de 
instrumental cirúrgico à temperatura de $134^{\circ} \mathrm{C}$ por 5 minutos. A qualificação térmica da autoclave com e sem carga por meio da realização de estudos de distribuição de temperatura, com utilização de termopares, para avaliação da condição de penetração do calor para cada tipo de carga e curva de pressão, além do cálculo de letalidade induzida pelo processo para alcançar a esterilização são essenciais para a garantia da segurança do processo de esterilização (Calicchio e Laranjeiras, 2010; Calicchio et al. 2011).

A esterilização do instrumental laparoscópico montado também foi objeto de estudo de outras pesquisas (Marshburn et al., 1991; Voyles et al., 1995 e Lopes, Graziano e Pinto, 2011), que permitem conclusões favoráveis quanto à prática de autoclavar os instrumentos laparoscópicos montados, embora algumas possuam limitações metodológicas.

A primeira pesquisa (Murshburn et al., 1991) teve como hipótese que o instrumento laparoscópico montado alcançaria a mesma segurança de esterilidade, quando comparado ao instrumental desmontado, utilizou a técnica de inoculação e recuperação de micro-organismos por meio de swab, com recuperação dos microorganismos desafio, tanto no instrumental laparoscópico esterilizado montado como no desmontado. Embora a técnica de recuperação microbiana por swab permita uma avaliação quantitativa, apresenta algumas limitações quanto à dificuldade em padronizar o arraste, o ângulo e o grau de pressão aplicados durante o procedimento, incapacidade de controlar a reprodutibilidade e a grande variabilidade nos resultados (Moore e Griffith, 2007).

Questiona-se o fato de Murshburn et al. (1991) não terem alcançado sucesso na esterilização com o material desmontado, considerada a melhor prática para autoclavação. Na presente investigação, obteve-se sucesso na esterilização do instrumental laparoscópico montado, bem como no desmontado.

Uma outra pesquisa realizada por Voyles et al. (1995) utilizou um dos componentes do instrumental laparoscópico, trocarter $12 \mathrm{~mm}$, com o lúmen totalmente preenchido com matéria orgânica (carne para hambúrguer) e contaminação desafio, para avaliar a eficácia da esterilização, utilizando temperatura de $132^{\circ} \mathrm{C}$ nos ciclos convencional e flash, com tempo de exposição de 10 e 3 minutos, respectivamente. Todos os micro-organismos vegetativos foram eliminados com esterilização nos ciclos convencional e flash. O preenchimento do lúmen com 
matéria orgânica representou uma resistência para o contato direto do vapor, similar ao que ocorre quando o instrumental laparoscópico é esterilizado montado.

Nas mesmas condições de desafio, com o preenchimento do lúmen com matéria orgânica, Voyles e seus colaboradores (1995) também testaram indicadores biológicos comercialmente disponíveis do Geobacillus stearothermophilus ATCC 7953, introduzidos no interior do lúmen do trocarter com e sem preenchimento de carne para hambúrger, e expostos a diferentes tempos 3, 4, 5, 6, 7 e 10 minutos. Nessas condições, foram recuperados esporos com 3, 4, 5 e 6 minutos de exposição. Somente com tempo de exposição estendido de 7 e 10 minutos, houve destruição total dos esporos. Esses resultados falam a favor da destruição microbiana por meio do calor latente, apesar do cenário desafiador quanto à contaminação desafio e presença maciça de matéria orgânica.

Considerando-se que os parâmetros padronizados para autoclave com prévácuo são $132^{\circ} \mathrm{C}$ por 4 minutos (AAMI, 2006; Rutala e Weber, 2008), a necessidade de Voyles e seus colaboradores (1995) expandirem os tempos de esterilização para obter êxito na eliminação total dos micro-organismos-testes pode estar relacionada com a alta concentração de matéria orgânica utilizada para o preenchimento do lúmen dos trocartes e não, obrigatoriamente, ao fato do instrumental estar montado. A presente investigação utilizou o mesmo desafio microbiológico e obteve sucesso na destruição dos esporos Geobacillus stearothermophilus ATCC 7953, utilizando o ciclo de esterilização a $134^{\circ} \mathrm{C}$ por 5 minutos.

Outra pesquisa (Lopes, Graziano e Pinto 2011) realizada para avaliar a eficácia da esterilidade dos instrumentos laparoscópicos de uso único, empregou como grupo comparativo instrumentos equivalentes reutilizáveis autoclavados previamente montados. Utilizou contaminação desafio com esporos bacterianos do Geobacillus stearothermophilus ATCC 7953 acrescido de 10\% de sangue de carneiro e esterilização a vapor, saturado sob pressão com pré-vácuo, à temperatura de $134^{\circ} \mathrm{C}$ por 5 minutos. Não houve recuperação do micro-organismo-teste naquele grupo, o que reforça a possibilidade de segurança da esterilização dos materiais montados.

A presente investigação contemplou a avaliação da eficácia dos diferentes métodos de limpeza, presumivelmente, praticados pelos CMEs do Brasil para instrumental laparoscópico reutilizável, quanto à redução de resíduos orgânicos de 
proteína, hemoglobina e carboidrato, após contaminação intencional com sangue de placenta humana. Esta etapa preliminar foi essencial para avaliar a segurança da esterilização do instrumental laparoscópico montado, uma vez que a presença de matéria orgânica pode proteger os micro-organismos comprometendo a esterilização, conforme os resultados publicados por Tosh e seus colaboradores (2011).

Os citados autores realizaram uma investigação de surto de infecções do sítio cirúrgico, após procedimentos artroscópicos causados por Pseudomonas aeruginosa. Conduziram um estudo caso-controle e realizaram culturas de amostras ambientais e de materiais cirúrgicos, sendo os micro-organismos isolados, analisados por técnica de biologia molecular (eletroforese em gel de campo pulsante - PFGE). Ao avaliar endoscopicamente o equipamento artroscópio (Shaver) processado, encontraram restos de tecido retido no lúmen de cânulas, tanto na entrada como na saída da peça de mão.

Os autores concluíram que as infecções de sítio cirúrgico, provavelmente, foram relacionadas com a contaminaçãodo instrumental cirúrgicodevido às falhas no processo de limpeza, evidenciada pela presença de tecido retido, o que poderia ter permitido que as bactérias sobrevivessem aos procedimentos de esterilização. Após mudanças nos protocolos de processamento de instrumentos, não ocorreu mais caso de infecção.

A preocupação com a presença de resíduos orgânicos também está relacionada com a formação e persistência de biofilmes microbianos nas superfícies do material. Liu e colaboradores (1994) estimaram quantitativamente a massa de biofilme baseados na concentração de polissacarídeos por meio da dosagem de carboidrato, demonstrando relação diretamente proporcional entre a massa de biofilme e a concentração de carboidrato. Os autores (Liu et al., 1994) também apontaram a determinação da concentração de proteína, como estratégia para estimar a presença de biofilme.

Para experimentos com a finalidade de avaliar os processos de limpeza, é crucial que sejam utilizadas soluções desafio que simulem a sujidade natural ou mesmo um pior cenário (Alfa, DeGagne e Oslon, 1999). Na presente investigação, foi usado sangue de placenta humana, como contaminação intencional para limpeza, com concentrações de proteína, carboidrato e hemoglobina superiores aos valores de resíduos orgânicos da pesquisa da Alfa, DeGagne e Oslon (1999) ao utilizar solução 
de Artificial Soil Test (ATS) ${ }^{10}$ cuja composição consiste em: proteínas $(85,2 \mathrm{mg} / \mathrm{mL})$, carboidratos $(85,2 \mathrm{mg} / \mathrm{mL})$ e hemoglobina $(4,12 \mathrm{mg} / \mathrm{mL})$. O Quadro 1 apresenta comparativamente as quantidades médias dos resíduos orgânicos do presente trabalho no instrumental laparoscópico, antes da limpeza, confrontados com as quantidades médias dos mesmos resíduos do trabalho de Alfa, DeGagne e Oslon (1999) nos endoscópios, sem limpeza.

Quadro 1 - Comparação entre os valores médios de proteína, carboidrato e hemoglobina presentes no instrumental laparoscópico, após contaminação intencional com sangue de placenta humana e no endoscópio após contaminação desafio com ATS, ambos sem limpeza. São Paulo, 2013.

\begin{tabular}{lccc}
\hline & \multicolumn{2}{c}{ Sangue de Placenta Humana } & ATS \\
& Pinça laparoscópica & Trocarte & Endoscópio \\
\hline Proteína & $183,07 \mu \mathrm{g} / \mathrm{cm}^{2}$ & $482,55 \mu \mathrm{g} / \mathrm{cm}^{2}$ & $37,05 \mu \mathrm{g} / \mathrm{cm}^{2}$ \\
Carboidrato & $17,89 \mu \mathrm{g} / \mathrm{cm}^{2}$ & $42,31 \mu \mathrm{g} / \mathrm{cm}^{2}$ & $4,69 \mu \mathrm{g} / \mathrm{cm}^{2}$ \\
Hemoglobina & $218,97 \mu \mathrm{g} / \mathrm{cm}^{2}$ & $615,05 \mu \mathrm{g} / \mathrm{cm}^{2}$ & $13,37 \mu \mathrm{g} / \mathrm{cm}^{2}$ \\
\hline
\end{tabular}

A avaliação da eficiência da limpeza pode ser realizada por meio da detecção de proteínas, carboidratos, hemoglobina, endotoxina, lipídios, íons de sódio e biocargas residuais ao processo, sendo o marcador de proteína o mais empregado (AAMI, 2006). Devem ser considerados o tipo de teste usado e o limite de detecção dos métodos (Alfa, 2006). Na presente investigação, foram utilizados métodos indiretos, sendo o volume total da solução de extração de $250 \mathrm{~mL}$, para deteccção de proteína, carboidrato e hemoglobina, com os respectivos limites de $\geq 0,5 \mu \mathrm{g} / \mathrm{mL}$, $\geq 10 \mu \mathrm{g} / \mathrm{mL}$ e $\geq 5 \mu \mathrm{g} / \mathrm{mL}$.

O método empregado permitiu avaliar toda a superficie do instrumental laparoscópico,após quatro diferentes métodos de limpeza, quais sejam: (1) limpeza manual com enxágue em água potável; (2) limpeza manual com enxágue em água potável, seguida de limpeza ultrassônica sem enxágue; (3) limpeza manual com enxágue em água potável, seguida de limpeza ultrassônica com enxágue em água potável e (4) limpeza manual com enxágue em água potável, seguida de limpeza

\footnotetext{
${ }^{10}$ ATS foi criado e patenteado (número da patente: 6,447.990) pela Prof ${ }^{\mathrm{a}}$. Dra. Michelle Alfa, com data de publicação de 24 de fevereiro de 2010.O ATS é composto de um meio básico, soro de bezerro, sangue de carneiro esterilizado e endotoxina, possui $85,2 \mathrm{mg} / \mathrm{mL}$ de proteínas, $12,3 \mathrm{mg} / \mathrm{mL}$ de carboidrato e $4,12 \mathrm{mg} / \mathrm{mL}$ de hemoglobina (disponível no site www.uspto.gov).
} 
ultrassônica com enxágue em água potável e último enxágue em água destilada esterilizada.

A literatura cita diferentes níveis aceitáveis de proteína residual, após a limpeza do material, utilizando diversificada referência para avaliação: uma área delimitada $\left(\mathrm{cm}^{2}\right)$, o volume do lúmen $(\mathrm{mL})$ ou toda superfície do material. Verjat, Prognon e Darbord (1999) sugerem como nível satisfatório <0,1 $\mu \mathrm{g} / \mathrm{material}$; DeBrujin, Orzechowshi e Wasseanaar (2001) definem como limite máximo aceitável

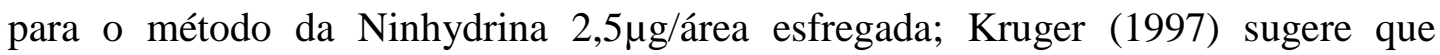
$>5,5 \mu \mathrm{g} / \mathrm{cm}^{2}$ de proteína residual o material é inaceitável como limpo e Alfa, DeGagne e Oslon (1999) apresentaram resultados de $<6,4 \mu \mathrm{g} / \mathrm{cm}^{2}$ nos canais de sucção de biopsia, após limpeza de rotina dos canais de biópsia/sucção de endoscópios flexíveis. Os últimos autores também indicaram valores médios para os marcadores de carboidrato $<1,8 \mu \mathrm{g} / \mathrm{cm}^{2}$ e hemoglobina $<2,2 \mu \mathrm{g} / \mathrm{cm}^{2}$ (Alfa, DeGagne e Oslon, 1999).

Todos os métodos de limpeza aqui avaliados obtiveram níveis médios de redução de proteínas inferiores aos valores de referências sugeridos por Kruger (1997), Alfa, DeGagne e Oslon (1999) e De Brujin, Orzechowshi e Wasseanaar (2001), os níveis de hemoglobina também inferiores ao valor indicado por Alfa, DeGagne e Oslon (1999). Apenas para a limpeza manual dos trocartes, os níveis médios de carboidratos foram superiores aos sugeridos por Alfa, DeGagne e Oslon (1999). Os dados comparativos estão sintetizados no Quadro 2, destacando em fonte vermelha quando o parâmetro estabelecido não foi alcançado. 
Quadro 02 - Comparação entre os valores médios de proteína, carboidrato e hemoglobina presentes no instrumental laparoscópico submetidos a diferente métodos de limpeza, confrontados com os referenciados pelos diversos autores da literatura. São Paulo, 2013.

\begin{tabular}{|c|c|c|c|c|c|}
\hline & & $\begin{array}{l}\text { Kruger } \\
\text { (1997) }\end{array}$ & $\begin{array}{l}\text { Alfa, } \\
\text { DeGagne e } \\
\text { Oslon } \\
(1999)\end{array}$ & $\begin{array}{l}\text { Verjat, Prognon } \\
\text { e Darbord } \\
(1999)\end{array}$ & $\begin{array}{l}\text { De Brujin, } \\
\text { Orzechowshi e } \\
\text { Wasseanaar } \\
(2001)\end{array}$ \\
\hline PROTEÍNA & & $>5,5 \mu \mathrm{g} / \mathrm{cm}^{2}$ & $<6,4 \mu \mathrm{g} / \mathrm{cm}^{2}$ & $<0,1 \mu \mathrm{g} /$ material & $\begin{array}{c}\text { 2,5 } \mathrm{g} \text { g/área } \\
\text { esfregada }\end{array}$ \\
\hline $\begin{array}{l}\text { (1) Limpeza manual } \\
\text { +enxágue em água }\end{array}$ & Pinça & $0,57 \mu \mathrm{g} / \mathrm{cm}^{2}$ & $0,57 \mu \mathrm{g} / \mathrm{cm}^{2}$ & $89 \mu \mathrm{g} /$ material & $0,57 \mu \mathrm{g} / \mathrm{cm}^{2}$ \\
\hline potável & Trocarte & $0,42 \mu \mathrm{g} / \mathrm{cm}^{2}$ & $0,42 \mu \mathrm{g} / \mathrm{cm}^{2}$ & $34 \mu \mathrm{g} /$ material & $0,42 \mu \mathrm{g} / \mathrm{cm}^{2}$ \\
\hline $\begin{array}{l}\text { (2) Limpeza manual + } \\
\text { USS }^{*}, \text { s/ enxágue }\end{array}$ & $\begin{array}{l}\text { Pinça } \\
\text { Trocarte }\end{array}$ & $\begin{array}{l}0,24 \mu \mathrm{g} / \mathrm{cm}^{2} \\
0,16 \mu \mathrm{g} / \mathrm{cm}^{2}\end{array}$ & $\begin{array}{l}0,24 \mu \mathrm{g} / \mathrm{cm}^{2} \\
0,16 \mu \mathrm{g} / \mathrm{cm}^{2}\end{array}$ & $\begin{array}{l}38 \mu \mathrm{g} / \text { material } \\
13 \mu \mathrm{g} / \text { material }\end{array}$ & $\begin{array}{l}0,24 \mu \mathrm{g} / \mathrm{cm}^{2} \\
0,16 \mu \mathrm{g} / \mathrm{cm}^{2}\end{array}$ \\
\hline $\begin{array}{l}\text { (3) Limpeza manual + } \\
\text { USS, c/ enxágue em } \\
\text { água potável }\end{array}$ & $\begin{array}{l}\text { Pinça } \\
\text { Trocarte }\end{array}$ & $\begin{array}{l}0,65 \mu \mathrm{g} / \mathrm{cm}^{2} \\
0,00 \mu \mathrm{g} / \mathrm{cm}^{2}\end{array}$ & $\begin{array}{l}0,65 \mu \mathrm{g} / \mathrm{cm}^{2} \\
0,00 \mu \mathrm{g} / \mathrm{cm}^{2}\end{array}$ & $\begin{array}{l}102 \mu \mathrm{g} / \text { material } \\
0 \mu \mathrm{g} / \text { material }\end{array}$ & $\begin{array}{l}0,65 \mu \mathrm{g} / \mathrm{cm}^{2} \\
0,00 \mu \mathrm{g} / \mathrm{cm}^{2}\end{array}$ \\
\hline $\begin{array}{l}\text { (4) Limpeza manual + } \\
\text { USS, c/ enxágue em } \\
\text { água potável + } \\
\text { enxágue final em água } \\
\text { destilada esterilizada }\end{array}$ & $\begin{array}{l}\text { Pinça } \\
\text { Trocarte }\end{array}$ & $\begin{array}{l}0,04 \mu \mathrm{g} / \mathrm{cm}^{2} \\
0,19 \mu \mathrm{g} / \mathrm{cm}^{2}\end{array}$ & $\begin{array}{l}0,04 \mu \mathrm{g} / \mathrm{cm}^{2} \\
0,19 \mu \mathrm{g} / \mathrm{cm}^{2}\end{array}$ & $\begin{array}{l}7 \mu \mathrm{g} / \text { material } \\
64 \mu \mathrm{g} / \text { material }\end{array}$ & $\begin{array}{l}0,04 \mu \mathrm{g} / \mathrm{cm}^{2} \\
0,19 \mu \mathrm{g} / \mathrm{cm}^{2}\end{array}$ \\
\hline CARBOIDRATO & & & $<6,4 \mu \mathrm{g} / \mathrm{cm}^{2}$ & & \\
\hline $\begin{array}{l}\text { (1) Limpeza manual } \\
\text { +enxágue em água } \\
\text { potável }\end{array}$ & $\begin{array}{l}\text { Pinça } \\
\text { Trocarte }\end{array}$ & & $\begin{array}{l}0,36 \mu \mathrm{g} / \mathrm{cm}^{2} \\
2,07 \mu \mathrm{g} / \mathrm{cm}^{2}\end{array}$ & & \\
\hline $\begin{array}{l}\text { (2) Limpeza manual + } \\
\text { USS }^{*} \text {, s/ enxágue }\end{array}$ & $\begin{array}{l}\text { Pinça } \\
\text { Trocarte }\end{array}$ & & $\begin{array}{l}1,25 \mu \mathrm{g} / \mathrm{cm}^{2} \\
0,00 \mu \mathrm{g} / \mathrm{cm}^{2}\end{array}$ & & \\
\hline $\begin{array}{l}\text { (3) Limpeza manual + } \\
\text { USS, c/ enxágue em } \\
\text { água potável }\end{array}$ & $\begin{array}{l}\text { Pinça } \\
\text { Trocarte }\end{array}$ & & $\begin{array}{l}0,45 \mu \mathrm{g} / \mathrm{cm}^{2} \\
0,69 \mu \mathrm{g} / \mathrm{cm}^{2}\end{array}$ & & \\
\hline $\begin{array}{l}\text { (4) Limpeza manual + } \\
\text { USS, c/ enxágue em } \\
\text { água potável + } \\
\text { enxágue final em água } \\
\text { destilada esterilizada }\end{array}$ & $\begin{array}{l}\text { Pinça } \\
\text { Trocarte }\end{array}$ & & $\begin{array}{l}0,15 \mu \mathrm{g} / \mathrm{cm}^{2} \\
0,00 \mu \mathrm{g} / \mathrm{cm}^{2}\end{array}$ & & \\
\hline HEMOGLOBINA & & & $<2,2 \mu \mathrm{g} / \mathrm{cm}^{2}$ & & \\
\hline $\begin{array}{l}\text { (1) Limpeza manual } \\
\text { +enxágue em água } \\
\text { potável }\end{array}$ & $\begin{array}{l}\text { Pinça } \\
\text { Trocarte }\end{array}$ & & $\begin{array}{l}0,10 \mu \mathrm{g} / \mathrm{cm}^{2} \\
0,00 \mu \mathrm{g} / \mathrm{cm}^{2}\end{array}$ & & \\
\hline $\begin{array}{l}\text { (2) Limpeza manual + } \\
\text { USS }^{*}, \text { s/ enxágue }\end{array}$ & $\begin{array}{l}\text { Pinça } \\
\text { Trocarte }\end{array}$ & & $\begin{array}{l}0,01 \mu \mathrm{g} / \mathrm{cm}^{2} \\
0,00 \mu \mathrm{g} / \mathrm{cm}^{2}\end{array}$ & & \\
\hline $\begin{array}{l}\text { (3) Limpeza manual + } \\
\text { USS, c/ enxágue em } \\
\text { água potável }\end{array}$ & $\begin{array}{l}\text { Pinça } \\
\text { Trocarte }\end{array}$ & & $\begin{array}{l}0,00 \mu \mathrm{g} / \mathrm{cm}^{2} \\
0,00 \mu \mathrm{g} / \mathrm{cm}^{2}\end{array}$ & & \\
\hline $\begin{array}{l}\text { (4) Limpeza manual + } \\
\text { USS, c/ enxágue em } \\
\text { água potável + } \\
\text { enxágue final em água } \\
\text { destilada esterilizada }\end{array}$ & $\begin{array}{l}\text { Pinça } \\
\text { Trocarte }\end{array}$ & & $\begin{array}{l}0,01 \mu \mathrm{g} / \mathrm{cm}^{2} \\
0,00 \mu \mathrm{g} / \mathrm{cm}^{2}\end{array}$ & & \\
\hline
\end{tabular}


Até o momento não há um consenso nos valores de referência e nos limites máximos aceitáveis para se considerar um material satisfatoriamente limpo (AAMI, 2006; Alfa, 2006). Os realistas defendem que os valores de referências devem ser compatíveis com o limite dos parâmetros possíveis de serem conseguidos por meio de limpeza de rotina, respeitando o limite de detecção do método de ensaio utilizado (AAMI, 2006).

Alfa e Nemes (2004) realizaram um estudo com o intuito de comparar os métodos de limpeza manual e ultrassônica para limpeza dos lumens de instrumentos descartáveis "portados" e "não portados", utilizados em procedimentos cirúrgicos minimamente invasivos. Utilizaram como contaminação desafio ATS. O lavado dos lumens, cujo volume variou de 0,34 a $1,71 \mathrm{~mL}$, foi avaliado por testes quantitativos indiretos para avaliar a quantidade de proteínas (Bradford $\left.{ }^{\circledR}\right)$, carboidratos e hemoglobina (TMB One ${ }^{\circledR}$ ). A limpeza dos lumensfoi considerada satisfatória ao atingir níveisde proteínas $<20 \mu \mathrm{g} / \mathrm{lúmen}$, carboidrato $<70 \mu \mathrm{g} / \mathrm{lúmen}$ e hemoglobina $<50 \mu \mathrm{g} / \mathrm{lúmen}$. A limpeza ultrassônica com retrofluxo proporcionou uma redução percentual de $99,9 \%$ das proteínas e $100 \%$ de hemoglobina para os instrumentos portados e não portados; para os carboidratos, a redução foi de $99,7 \%$ nos portados e $99,5 \%$ nos não portados. Os autores concluíram que o método de limpeza por meio da lavadora ultrassônica automatizada com retrofluxo para lumens estreitos foi mais eficaz que a limpeza manual.

Comparando os resultados aqui obtidos, na avaliação de toda superfície do instrumental laparoscópico, com o referencial proposto por Alfa e Nemes (2004) para limpeza de lúmen, os níveis médios de proteínas foram inferiores ao referencial proposto para limpeza de lúmen, apenas para as pinças laparoscópicas submetidas à limpeza (4) e para os trocartes submetidos aos métodos (2) e (3), e os níveis médios de carboidratos foram inferiores exceto para pinças laparoscópicas no método (2) e para os trocartes no método (1), sendo os níveis de hemoglobina inferiores em todas as análises (Quadro 3). Deve-se considerar que o lúmen representa apenas a estrutura interna de uma das peças do instrumental laparoscópico, destacado em fonte vermelha quando o parâmetro estabelecido não foi alcançado. 
Quadro 03 - Comparação entre os valores médios de proteína, carboidrato e hemoglobina presentes no instrumental laparoscópico submetidos a diferente métodos de limpeza, confrontados com os referenciados por Alfa e Nemes (2004) para limpeza de lúmen. São Paulo, 2013.

\begin{tabular}{|c|c|c|c|c|}
\hline & & \multicolumn{3}{|c|}{ Alfa e Nemes (2004) } \\
\hline & & $\begin{array}{l}\text { Proteína } \\
<20 \mu \mathrm{g} / \mathrm{lúmen}\end{array}$ & $\begin{array}{l}\text { Carboidrato } \\
<70 \mu \mathrm{g} / \mathrm{lúmen} \\
\end{array}$ & $\begin{array}{l}\text { Hemoglobina } \\
<50 \mu \mathrm{g} / \text { lúmen }\end{array}$ \\
\hline \multirow{2}{*}{$\begin{array}{l}\text { (1) Limpeza manual +enxágue } \\
\text { em água potável }\end{array}$} & Pinça & $89 \mu \mathrm{g} /$ pinça & $56 \mu \mathrm{g} /$ pinça & $16 \mu \mathrm{g} / \mathrm{pinça}$ \\
\hline & Trocarte & $34 \mu \mathrm{g} /$ trocarte & $167 \mu \mathrm{g} /$ trocarte & $0 \mu \mathrm{g} /$ trocarte \\
\hline \multirow{2}{*}{$\begin{array}{l}\text { (2) Limpeza manual + USS } \\
\text { s/ enxágue }\end{array}$} & Pinça & $38 \mu \mathrm{g} /$ pinça & $195 \mu \mathrm{g} / \mathrm{pinça}$ & $1 \mu \mathrm{g} / \mathrm{pinça}$ \\
\hline & Trocarte & $13 \mu \mathrm{g} /$ trocarte & $0 \mu \mathrm{g} /$ trocarte & $0 \mu \mathrm{g} /$ trocarte \\
\hline \multirow{2}{*}{$\begin{array}{l}\text { (3) Limpeza manual + USS, c/ } \\
\text { enxágue em água potável }\end{array}$} & Pinça & $102 \mu \mathrm{g} /$ pinça & $70 \mu \mathrm{g} /$ pinça & $0 \mu \mathrm{g} /$ pinça \\
\hline & Trocarte & $0 \mu \mathrm{g} /$ trocarte & $56 \mu \mathrm{g} /$ trocarte & $0 \mu \mathrm{g} /$ trocarte \\
\hline \multirow{2}{*}{$\begin{array}{l}\text { (4) Limpeza manual + USS, c/ } \\
\text { enxágue em água potável + } \\
\text { enxágue final em água } \\
\text { destilada esterilizada }\end{array}$} & Pinça & $7 \mu \mathrm{g} /$ pinça & $23 \mu \mathrm{g} /$ pinça & $2 \mu \mathrm{g} /$ pinça \\
\hline & Trocarte & $64 \mu \mathrm{g} /$ trocarte & $0 \mu \mathrm{g} /$ trocarte & $0 \mu \mathrm{g} /$ trocarte \\
\hline
\end{tabular}

O teste estatístico inferencial aplicado de Kruskal-Walis, não foi capaz de detectar diferença em todas as comparações múltiplas, das quantidades médias dos resíduos orgânicos das pinças laparoscópicas e dos trocartes, entre os quatro métodos de limpeza entre si ( $p>0,05$ ), bem como dentre eles com o controle negativo ( $>0,05)$. O que não significa afirmar que o desempenho dos métodos testados foram equivalentes.

Ressalta-se que, além do pequeno tamanho amostral, houve uma grande variabilidade nos resultados dos valores mínimos e máximos obtidos de proteína, carboidrato e hemoglobina, conforme apresentado nas tabelas 4 e 5 , o que impossibilitou conclusões estatísticas com maior poder.

Quando se analisa o valor médio de resíduos nas pinças laparoscópicas, o método de limpeza (4), denominado no trabalho como gold standard, alcançou a maior redução percentual de proteínas e carboidratos, quando comparado com outros métodos de limpeza. Proporcionalmente, no método de limpeza (4) restaram 92\% a menos de $\mu \mathrm{g} /$ proteína por pinça laparoscópica, quando comparado com o método (1). O mesmo foi evidenciado para o carboidrato, sendo a proporção de $40 \%$ $\mu \mathrm{g} /$ carboidrato a menos no método de limpeza (4), quando comparado com o método (1).

Ao analisar o valor médio de resíduos nos trocartes, o método de limpeza (4), denominado no trabalho como gold, standard, alcançou redução percentual 99,8\% 
$\mu \mathrm{g} /$ proteína/trocarte e $100 \% \mu \mathrm{g} /$ carboidrato/trocarte. Proporcionalmente, no método de limpeza (4) restaram $88 \%$ de proteína a mais por trocarte, quando comparado com o método (1); e para carboidrato restaram, em média, $41 \%$ a menos no método de limpeza (4), quando comparado com o método (1).

Para o resíduo de hemoglobina, o resultado satisfatório de redução de $100 \%$ (desvio padrão $=0,0)$ também foi alcançado pelos métodos $(2)$ e $(3)$, menos rigorosos de limpeza, sinalizando ser um resíduo orgânico de mais fácil remoção.

Embora as diferenças percentuais dos resíduos orgânicos quantificados, tenham sido na ordem de décimos, quando transformados na dimensão dos valores em $\mu \mathrm{g} /$ instrumental, significa dizer que após a limpeza ainda restaram resíduos nas as pinças e trocartes laparoscópicos, conforme apresentado nas tabelas 4 e 5 e sintetizado no Quadro 04, para melhorar a clareza da exposição.

Quadro 04 - Síntese dos resultados da redução percentual média dos resíduos orgânicos de proteína, carboidrato e hemoglobina no instrumental laparoscópico após diferentes métodos de limpeza, e os respectivos valores em $\mu \mathrm{g} /$ instrumental. São Paulo, 2013.

\begin{tabular}{|c|c|c|c|c|c|c|}
\hline \multirow[b]{2}{*}{ Grupos de Estudo } & \multicolumn{2}{|c|}{ PROTEÍNA } & \multicolumn{2}{|c|}{ CARBOIDRATO } & \multicolumn{2}{|c|}{ HEMOGLOBINA } \\
\hline & redução \% & $\begin{array}{l}\text { Média } \\
\text { residual }\end{array}$ & redução \% & Média residual & redução \% & $\begin{array}{l}\text { Média } \\
\text { residual }\end{array}$ \\
\hline \multicolumn{7}{|l|}{$\begin{array}{l}\text { (1) Manual + } \\
\text { enxágue em água } \\
\text { potável }\end{array}$} \\
\hline Pinça laparoscópica & 99,7 & $89 \mu \mathrm{g} /$ pinça & 98,0 & $56 \mu \mathrm{g} /$ pinça & 100,0 & $16 \mu \mathrm{g} / \mathrm{pinça}$ \\
\hline Trocarte & 99,93 & $34 \mu \mathrm{g} /$ trocarte & 95,1 & $167 \mu \mathrm{g} /$ trocarte & 100,0 & 0 \\
\hline \multicolumn{7}{|l|}{$\begin{array}{l}\text { (2) Limpeza } \\
\text { manual + USS, s/ } \\
\text { enxágue }\end{array}$} \\
\hline Pinça laparoscópica & 99,9 & $38 \mu \mathrm{g} /$ pinça & 93,0 & $195 \mu \mathrm{g} /$ pinça & 100,0 & $1 \mu \mathrm{g} / \mathrm{pinça}$ \\
\hline Trocarte & 100,0 & $13 \mu \mathrm{g} /$ trocarte & 100,0 & 0 & 100,0 & 0 \\
\hline \multicolumn{7}{|l|}{$\begin{array}{l}\text { (3) Limpeza } \\
\text { manual + USS, c/ } \\
\text { enxágue em água } \\
\text { potável }\end{array}$} \\
\hline Pinça laparoscópica & 99,6 & $102 \mu \mathrm{g} /$ pinça & 97,5 & $70 \mu \mathrm{g} /$ pinça & 100,0 & 0 \\
\hline Trocarte & 100,0 & 0 & 98,5 & $56 \mu \mathrm{g} /$ trocarte & 100,0 & 0 \\
\hline \multicolumn{7}{|l|}{$\begin{array}{l}\text { (4) Limpeza } \\
\text { manual + USS, c/ } \\
\text { enxágue em água } \\
\text { potável + enxágue } \\
\text { final em água } \\
\text { destilada } \\
\text { esterilizada }\end{array}$} \\
\hline Pinça laparoscópica & 100,0 & $7 \mu \mathrm{g} /$ pinça & 99,2 & $23 \mu \mathrm{g} /$ pinça & 100,0 & 2 \\
\hline Trocarte & $99,8 \quad 6$ & $64 \mu \mathrm{g} /$ trocarte & 100,0 & 0 & 100,0 & 0 \\
\hline
\end{tabular}


Especificamente relacionada a limpeza do instrumental laparoscópico, ao confrontar os resultados da presente investigação com o da literatura relacionada (Alfa e Nemes, 2004), o método de limpeza incluindo a limpeza ultrassônica também se mostrou mais eficaz no trabalho das autoras, resultado este não detectado, no presente trabalho, para o resíduo de proteína nos trocartes.

Na prática do processamento de materiais em CME, há de se considerar a possibilidade cumulativa da deposição de resíduos de proteínas e carboidratos durante os processamentos sequenciais do material. Uma vez que o grupo Controle Negativo da presente investigação avaliou instrumental novo e sem contaminação intencional, pode-se afirmar que foram obtidos os melhores valores quanto à acurácia e confiabilidade da melhor condição de limpeza que um instrumental laparoscópico pode alcançar: média de proteína de $13 \mu \mathrm{g} /$ pinça $\left(0,08 \mu \mathrm{g} / \mathrm{cm}^{2}\right)$, após limpeza manual e $55 \mu \mathrm{g} /$ trocarte $\left(0,68 \mu \mathrm{g} / \mathrm{cm}^{2}\right)$, após limpeza ultrassônica; e para os carboidratos $47 \mu \mathrm{g} /$ pinça $\left(0,30 \mu \mathrm{g} / \mathrm{cm}^{2}\right)$, para limpeza manual e $56 \mu \mathrm{g} /$ pinça $\left(0,36 \mu \mathrm{g} / \mathrm{cm}^{2}\right)$, para limpeza ultrassônica.

Outro resultado a ser retomado, refere-se ao grupo que testou a limpeza manual com enxágue em água potável, seguida de limpeza ultrassônica sem enxágue. Embora não tenha havido diferença estatística nos resíduos de proteínas, carboidratos e hemoglobina, a presente investigação não avaliou todos os possíveis resíduos passíveis de remoção aos enxágües, de modo a prevenir reações pirogênicas nos pacientes e/ou danos estruturais ao instrumental, portanto, os resultados apresentados não permitiram abolir o enxágue após a limpeza ultrassônica. 
7 CONCLUSÃo 


\section{CONCLUSÃo}

A presente investigação trouxe respostas consistentes e plausíveis para contrariar as recomendações clássicas de que todo material deve ser autoclavado desmontado, particularmente, o instrumental laparoscópico. Os experimentos demonstraram segurança microbiológica da esterilização a vapor de pinças laparoscópicas e trocarte $5 \mathrm{~mm}$ de diâmetros previamente montados. Considerando os instrumentos amostrados como os mais complexos dentre o arsenal laparoscópico, assume-se a afirmação de poder extrapolar a segurança em esterilizar outros itens que compõem o mesmo arsenal previamente montado, como agulha de Veress, aspirador/irrigador, aspirador com eletrocautério, dentre outros modelos de pinças laparoscópicas.

Secundariamente, dentro da crença de que a garantia da limpeza é um prérequisito para o sucesso da esterilização, a presente investigação permitiu concluir que a pinça laparoscópica e o trocarte analisados são passíveis de limpeza eficiente. Embora, estatisticamente, os quatro métodos de limpeza avaliados na presente investigação não tenham evidenciado diferenças significantes entre si nos desfechos da redução de resíduos orgânicos (valor $p>0,05$ ), não se pode afirmar que o desempenho dos métodos testados foram equivalentes. Devido o pequeno tamanho amostral e grande variabilidade entre os valores mínimos e máximos, a estatística inferencial não se mostrou como um recurso sensível o suficiente para permitir conclusões estatísticas com maior poder.

As análises em unidades de $\mu \mathrm{g} /$ instrumental demostraram que o método de limpeza (4) gold standard (limpeza manual, seguida da ultrassônica com enxágue em água potável, e rinsagem final em água destilada esterilizada) removeu, em média, $92 \%$ a mais de $\mu \mathrm{g} /$ proteína/pinça laparoscópica e $40 \%$ a mais de $\mu \mathrm{g} /$ carboidrato/pinça laparoscópica e por trocarte, quando comparado com o método (1), de limpeza manual com enxágue em água potável, embora esta superioridade da limpeza (4) não tenha sido observada de uma forma uniforme em todo o experimento.

Em que pese a robustez da condução metodológica adotada nesta investigação, os resultados desta pesquisa trouxeram à Enfermagem brasileira que atua em CME a segurança de autoclavar o instrumental laparoscópico montado. Adicionalmente, enseja-se que esses resultados subsidiem também os legisladores, 
Tamara Carolina de Camargo

para que seja formalizada a possibilidade de autoclavação do instrumental laparoscópico previamente montado. 
REFERÊNCIAS 


\section{REFERÊNCIAS}

Alfa MJ, DeGagne P, Oslon N. Worst-case soiling levels for patient-used flexible endoscopes before and after cleaning. Am J Infeci Control 1999;27:392-401.

Alfa MJ, Nemes R. Manual versus automated methods for cleaning reusable acessory devices used for minimally invasive surgical procedures. J Hosp Infect. 2004;58(1):50-8.

Alfa MJ. Cleaning: recent advances in products and processes and real-time monitoring. In: Rutala WA. Disinfection, sterilization, and antisepsis: principles, practices, current issues, and new research. Florida, 2006. p.60-71

Alfa MJ, Oslon N, DeGagne P. Automated washing with the Reliance Endoscope Processing System and its equivalence to optimal manual cleaning. Am J Infect Controle 2006;34:561-70.

Associação Brasileira de Normas Técnicas (ABNT). NBR ISO 17665-1: Esterilização de produtos para saúde - Vapor. Parte 1: Requisitos para o desenvolvimento, validação e controle de rotina nos processos de esterilização de produtos para saúde. Rio de Janeiro; 2010.

Association for the Advancement Instrumentation (AAMI). Comprehensive guide to steam sterilization and sterility assurance in health care facilities. Arlington: AAMI, 2006. 190p.

Association of Perioperative Registred Nurse. Recommended Practices for Sterilization in the Perioperative Practice Setting. In: Perioperative Standards and Recommended Practices. Denver: AORN; 2012. p.547-69.

Brasil. Ministério da Saúde. Fundação Oswaldo Cruz. Instituto Nacional de Controle de Qualidade em Saúde. Procedimento Operacional Padronizado: Método para avaliação da atividade esporocida. Rio de Janeiro. 2009.

Brasil. Ministério da Saúde. Portaria n. 2914, de 12 de dezembro de 2011. Dispõe sobre os procedimentos de controle e de vigilância da qualidade da água para 
Tamara Carolina de Camargo

consumo humano e seu padrão de potabilidade. Diário Oficial da União, Poder Executivo, Brasília (DF) 2011dez. 14.

Brasil. Ministério da Saúde. Agência Nacional de Vigilância Sanitária. Resolução da Diretoria Colegiada n. 15, de 15 de março de 2012. Dispõe sobre requisitos de boas práticas para o processamento de produtos para saúde e dá outras providências. Diário Oficial da União, Poder Executivo, Brasília (DF) 2012 mar. 19.

Bergo MCNC. Avaliação do desempenho da limpeza e desinfecção das máquinas lavadoras desinfectadoras automáticas em programas com diferentes tempo e temperatura. Rev. Latino-Am. Enfermagem [internet]. set-out 2016 [acesso em: 26 abril 2013];14(5):[07 telas]. Disponível em: http://dx.doi.org/10.1590/S010411692006000500015 .

Bergo MCNC, Graziano KU. Validação das máquinas lavadoras desinfectadoras automáticas conforme normas ISSO 15.883 e HTM 2030. R Enferm UERJ. 2005; $13: 238-44$.

Calicchio LG, Laranjeiras PR. Controle de esterilização: monitoramento e validação do processo. In: Padoveze MC, Graziano KU, coordenadores. Limpeza, desinfecção e esterilização de artigos em serviços de saúde. São Paulo: APECIH; 2010. p.193218.

Calicchio LG, Laranjeiras PR, Graziano KU, Moriya GAA. Controle de esterilização e desinfecção. In: Graziano KU, Silva A, Psaltikidis EM, organizadoras. Enfermagem em centro de material e esterilização. São Paulo: Manole, 2011. p.20436.

Camargo TC. Eficácia da esterilização a vapor de instrumental laparoscópico montado versus desmontado: um estudo experimental [dissertação]. São Paulo: Escola de Enfermagem, Universidade de São Paulo; 2007.

Caregnato RCA, Lautert L. O estresse da equipe multiprofissional na Sala de Cirurgia. Rev. Bras Enferm. 2005; 58(5):545-50. 
Chandio A, Timmons S, Majeed A, Twomey A, Aftab F. Factors influencing the successful completion of laparoscopic choclecystectomy. JSLS. 2009;13(4):581-6.

Chow SC, Shao J, Wang H. Sample size calculations in clinical research. 2nd ed. Boca Raton (FL): Chapman \& Hall; 2008.

Committee on Infection Control in the Handling of Endoscopic Equipment. Guidelines for preparation of laparoscopic instrumentation. AORN J. 1980; 32(1):6576.

De Bruijn ACP, Orzechowshi TJH, Wasseanaar C. Validation of the ninhydrin swab test to monitor cleaning of medical instruments. ZentrSteril 2001;9(4);235-247.

Dimas A, Mulazzani MP, Cioato MJG, Rocha RR. Equipamentos utilizados em videocirurgia. In: Mulazzani MP, Cioato MJG. Enfermagem em videocirurgia: fundamentos, procedimentos e prática. São Paulo: Atheneu, 2006. p.9-30.

Feitosa AS, Camargo TC, Graziano KU. A prática do processamento do instrumental laparoscópico montado versus desmontado [monografia]. São Paulo: Escola de Enfermagem, Universidade de São Paulo; 2011.

Francis MJ, Pashley RM. Application of a bubble column for evaporative cooling and a simple procedure for determining the latent heat of vaporization of aqueous salt solutions. J PhysChem B. 2009;113(27):9311-5.

Galvão CM, Sawada NO, Rosse LA. A prática baseada em evidências: considerações teóricas para sua implementação na enfermagem perioperatória. Rev. Latino-Am. Enfermagem. 2002;10(5):690-5.

Graziano KU. Processo de limpeza, desinfecção e esterilização de artigos odontomédico hospitalares e cuidados com ambiente em centro cirúrgico. In: Lacerda RA, coordenadora. Controle de infecção em centro cirúrgico: fatos, mitos e controvérsias. São Paulo: Atheneu; 2003. p.163-95.

Kruger S. Testing the cleaning efficacy in decontamination equipment. Zentr. Steril., 5:332-44, 1997. 
Tamara Carolina de Camargo

Liu D, Lau YD, Chau YK, Pacepavicius G. Simple technique for estimation biofilm accumulation. Bull. Environ. Contam. Toxicol. 53:913-8, 1994.

Lopes CLBC, Graziano KU, Pinto TJA. Evaluation of Single-use Reprocessed Laparoscopic Instrument Sterilization. Rev. Latino-Am. Enfermagem [internet]. marabr 2011 [acesso em: 13 outubro 2011];19(2):[08 telas]. Disponível em: http://dx.doi.org/10.1590/S0104-1169201100020020.

Marshburn PB, Rutala WA, Wannamaker NS, Hulka JF. Gas and steam sterilization of assembled versus disassembled laparoscopic equipment. Microbiologic studies. J Reprod Med. 1991;36(7):483-7.

Moore G, Griffith. Problems associated with traditional hygiene swabbing: the need for in-house standardization. Journal of Applied Microbiology. 2007. 1090-1103.

Nasi A, Domene CE, Santo MA, Pinotti HW. Equipamentos e instrumental. In: Pinotti HW, Domene CE. Cirurgia vídeo laparoscópica. São Paulo: Robe; 1993. p. 73-87.

Padoveze MC, Quelhas MC, Nakamura Yoshida MH. Métodos físicos de Esterilização. In: Padoveze MC, Graziano KU, coordenadores. Limpeza, desinfecção e esterilização de artigos em serviços de saúde. São Paulo: APECIH; 2010. p.108-25.

Padoveze MC, Quelhas MC, Nakamura Yoshida MH. Esterilização por métodos físicos. In: Graziano KU, Silva A, Psaltikidis EM, organizadoras. Enfermagem em centro de material e esterilização. São Paulo: Manole, 2011. p.109-30.

Padoveze MC. Limpeza, desinfecção e esterilização: aspectos gerais. In: Padoveze MC, Graziano KU, coordenadores. Limpeza, desinfecção e esterilização de artigos em serviços de saúde. São Paulo: APECIH; 2010. p.1-35.

Padoveze MC, Graziano KU. Aspectos conceituais e microbiológicos relacionados ao processamento de materiais utilizados na assistência à saúde. In: Graziano KU, Silva A, Psaltikidis EM, organizadoras. Enfermagem em centro de material e esterilização. São Paulo: Manole, 2011. p.22-61. 
Perkins JJ. Principles of steam sterilization. In: Principles and methods of steam sterilization in health science. 2nd. ed. Springfield: Charles C Thomas, 1983. p.11011.

Psaltikidis EM, Ribeiro SMPC. Recepção e limpeza dos materiais. In: Graziano KU, Silva A, Psaltikidis EM, organizadoras. Enfermagem em centro de material e esterilização. São Paulo: Manole, 2011. p.62-91.

Pinto TJ, Kaneko TM, Ohara MT. Controle biológico de qualidades de produtos farmacêuticos, correlatos e cosméticos. 3a ed. São Paulo: Atheneu; 2010. 804p.

Ribeiro SMCP. Limpeza. In: Padoveze MC, Graziano KU, coordenadores. Limpeza, desinfecção e esterilização de artigos em serviços de saúde. São Paulo: APECIH; 2010. p.57-82.

Rutala WA, Weber JD. Healthcare Infection Control Practices Advisory Committee (HICPAC). Guideline for disinfection and sterilization in healthcare facilities, Atlanta: CDC; 2008.158p.

Sociedade Brasileira de Enfermeiros de Centro Cirúrgico, Recuperação Anestésica e Centro de Material e Esterilização (SOBECC). Práticas Recomendadas. 5a .ed. São Paulo: SOBECC; 2009.

Tosh PK, Disbot M, Duffy JM, Boom ML, Heseltine G, Srinivasan A, Gould CV, Berríos-Torres SI. Outbreak of Pseudomonas aeruginosa Surgical Site Infections after Arthroscopic Procedures: Texas, 2009. Infect Control Hosp Epidemiol 2011;32(12):1179-1186.

Verjat D, Prognon P, Darbord JC. Fluorescence-assay on traces of protein on reusable medical devices: cleaning efficiency. International $\mathrm{J}$ Pharmaceutics 1999;179:267-71.

Voyles CR, Sanders DL, Simons JE, Mcvey EA, Wilson WB. Steam sterilization of laparoscopic instruments. Surg Laparoscopc Endosc. 1995;5(2):139-41. 
APÊNDICES 

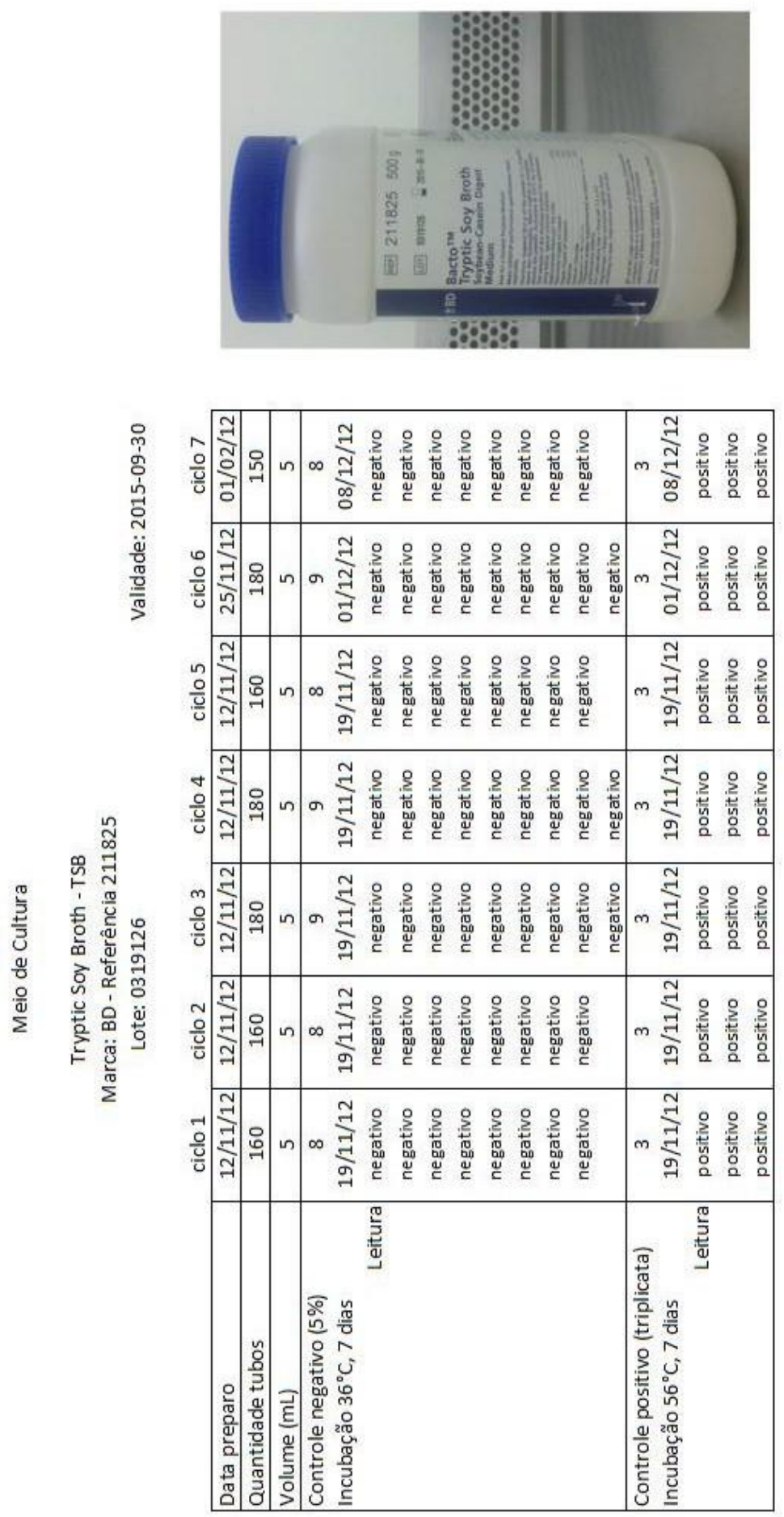
Apêndice B - Registro dos Resultados dos Testes de Análise dos Resíduos Orgânicos de Proteína, Carboidrato e Hemoglobina no INSTRUMENTAL LAPAROSCÓPICO

\section{PINÇAS LAPAROSCÓPICAS}

\begin{tabular}{|c|c|c|c|c|c|c|c|}
\hline & \multicolumn{2}{|c|}{ Proteína } & \multicolumn{2}{|c|}{ Carboidrato } & \multicolumn{2}{|c|}{ Hemoglobina } \\
\hline & & $\mu g /$ pinça & $\mu \mathrm{g} / \mathrm{cm}^{2}$ & $\mu g /$ pinça & $\mu \mathrm{g} / \mathrm{cm}^{2}$ & $\mu \mathrm{g} /$ pinça & $\mu \mathrm{g} / \mathrm{cm}^{2}$ \\
\hline \multirow[t]{9}{*}{ Controle positivo } & P1 & 8996,10 & 57,67 & 1465,34 & 9,39 & 8029,39 & 51,47 \\
\hline & P2 & 26606,40 & 170,55 & 1535,12 & 9,84 & 27159,43 & 174,10 \\
\hline & P3 & 11117,82 & 71,27 & 1535,12 & 9,84 & 12778,52 & 81,91 \\
\hline & P4 & 7171,42 & 45,97 & 1744,46 & 11,18 & 10647,80 & 68,26 \\
\hline & P5 & 40715,85 & 261,00 & 2093,35 & 13,42 & 34509,55 & 221,22 \\
\hline & P6 & 25184,84 & 161,44 & 767,56 & 4,92 & 42219,62 & 270,64 \\
\hline & P7 & 31316,62 & 200,75 & 1395,57 & 8,95 & 53134,48 & 340,61 \\
\hline & P8 & 61296,55 & 392,93 & 7536,06 & 48,31 & 52762,91 & 338,22 \\
\hline & P9 & 44619,82 & 286,02 & 7047,61 & 45,18 & 66185,87 & 424,27 \\
\hline \multirow{5}{*}{$\begin{array}{l}\text { Limpeza manual + enxágue } \\
\text { em água potável }\end{array}$} & P1 & 360,69 & 2,31 & 209,33 & 1,34 & 17,42 & 0,11 \\
\hline & P2 & 21,22 & 0,14 & 0,00 & 0,00 & 46,45 & 0,30 \\
\hline & P3 & 0,00 & 0,00 & 0,00 & 0,00 & 0,00 & 0,00 \\
\hline & P4 & 63,65 & 0,41 & 0,00 & 0,00 & 0,00 & 0,00 \\
\hline & P5 & 0,00 & 0,00 & 69,78 & 0,45 & 17,42 & 0,11 \\
\hline \multirow{5}{*}{$\begin{array}{c}\text { Limpeza manual + USS, s/ } \\
\text { enxágue }\end{array}$} & P1 & 127,30 & 0,82 & 69,78 & 0,45 & 5,81 & 0,04 \\
\hline & P2 & 0,00 & 0,00 & 209,33 & 1,34 & 0,00 & 0,00 \\
\hline & P3 & 0,00 & 0,00 & 0,00 & 0,00 & 0,00 & 0,00 \\
\hline & P4 & 0,00 & 0,00 & 697,78 & 4,47 & 0,00 & 0,00 \\
\hline & P5 & 63,65 & 0,41 & 0,00 & 0,00 & 0,00 & 0,00 \\
\hline \multirow{5}{*}{$\begin{array}{l}\text { Limpeza manual + USS c/ } \\
\text { enxágue em água potável }\end{array}$} & P1 & 63,65 & 0,41 & 0,00 & 0,00 & 0,00 & 0,00 \\
\hline & P2 & 233,39 & 1,50 & 139,56 & 0,89 & 0,00 & 0,00 \\
\hline & P3 & 84,87 & 0,54 & 209,33 & 1,34 & 0,00 & 0,00 \\
\hline & P4 & 0,00 & 0,00 & 0,00 & 0,00 & 0,00 & 0,00 \\
\hline & P5 & 127,30 & 0,82 & 0,00 & 0,00 & 0,00 & 0,00 \\
\hline \multirow{3}{*}{$\begin{array}{l}\text { Limpeza manual + USS, c/ } \\
\text { enxague em água potável + } \\
\text { enxágue final em água } \\
\text { destilada esterilizada }\end{array}$} & P1 & 0,00 & 0,00 & 69,78 & 0,45 & 5,81 & 0,04 \\
\hline & P2 & 0,00 & 0,00 & 0,00 & 0,00 & 0,00 & 0,00 \\
\hline & P3 & 21,22 & 0,14 & 0,00 & 0,00 & 0,00 & 0,00 \\
\hline \multirow{3}{*}{$\begin{array}{c}\text { Controle negativo (limpeza } \\
\text { manual e enxágue em água } \\
\text { potável) }\end{array}$} & $P 1$ & 0,00 & 0,00 & 0,00 & 0,00 & 0,00 & 0,00 \\
\hline & P2 & 17,60 & 0,11 & 0,00 & 0,00 & 0,00 & 0,00 \\
\hline & P3 & 21,75 & 0,14 & 140,00 & 0,90 & 0,00 & 0,00 \\
\hline \multirow{3}{*}{$\begin{array}{l}\text { Controle negativo (limpeza } \\
\text { manual + USS c/enxágue } \\
\text { em água potável + enxágue } \\
\text { final em água destilada } \\
\text { esterilizada ) }\end{array}$} & P1 & 0,00 & 0,00 & 167,00 & 1,07 & 0,00 & 0,00 \\
\hline & P2 & 0,00 & 0,00 & 0,00 & 0,00 & 0,00 & 0,00 \\
\hline & P3 & 0,00 & 0,00 & 0,00 & 0,00 & 0,00 & 0,00 \\
\hline
\end{tabular}

Observações: "USS - limpeza com lavadora ultrassônica específica para materiais canulados, com sistema de bombeamento pulsante retrofluxo. Considerou-se como 0 resultados menores que o limite detecção para o teste, não significando necessariamente ausência. 


\section{TROCARTES}

\begin{tabular}{|c|c|c|c|c|c|c|c|}
\hline & \multicolumn{2}{|c|}{ Proteína } & \multicolumn{2}{|c|}{ Carboidrato } & \multicolumn{2}{|c|}{ Hemoglobina } \\
\hline & & $\mu \mathrm{g} /$ trocarte & $\mu \mathrm{g} / \mathrm{cm}^{2}$ & $\mu \mathrm{g} /$ trocarte & $\mu \mathrm{g} / \mathrm{cm}^{2}$ & $\mu \mathrm{g} /$ trocarte & $\mu \mathrm{g} / \mathrm{cm}^{2}$ \\
\hline \multirow[t]{9}{*}{ Controle positivo } & T1 & 103815,87 & 1281,68 & 6698,72 & 82,70 & 40988,80 & 506,03 \\
\hline & $\mathrm{T} 2$ & 10735,91 & 132,54 & 1814,24 & 22,40 & 7878,44 & 97,26 \\
\hline & T3 & 4413,18 & 54,48 & 69,78 & 0,86 & 1701,09 & 21,00 \\
\hline & T4 & 25948,66 & 320,35 & 1465,34 & 18,09 & 48002,18 & 592,62 \\
\hline & T5 & 43219,48 & 533,57 & 8233,84 & 101,65 & 46469,45 & 573,70 \\
\hline & T6 & 83871,68 & 1035,45 & 9489,85 & 117,16 & 124940,35 & 1542,47 \\
\hline & $\mathrm{T} 7$ & 12157,47 & 150,09 & 488,45 & 6,03 & 18323,04 & 226,21 \\
\hline & T8 & 25821,36 & 318,78 & 1395,57 & 17,23 & 31409,26 & 387,77 \\
\hline & T9 & 41797,93 & 516,02 & 1186,23 & 14,64 & 128656,05 & 1588,35 \\
\hline \multirow{5}{*}{$\begin{array}{c}\text { Limpeza manual + } \\
\text { enxágue em água } \\
\text { potável }\end{array}$} & T1 & 42,43 & 0,52 & 69,78 & 0,86 & 0,00 & 0,00 \\
\hline & $\mathrm{T} 2$ & 21,22 & 0,26 & 0,00 & 0,00 & 0,00 & 0,00 \\
\hline & T3 & 0,00 & 0,00 & 69,78 & 0,86 & 0,00 & 0,00 \\
\hline & T4 & 0,00 & 0,00 & 209,33 & 2,58 & 0,00 & 0,00 \\
\hline & T5 & 106,09 & 1,31 & 488,45 & 6,03 & 0,00 & 0,00 \\
\hline \multirow{5}{*}{$\begin{array}{c}\text { Limpeza manual + } \\
\text { USS, s/ enxágue }\end{array}$} & $\mathrm{T} 1$ & 63,65 & 0,79 & 0,00 & 0,00 & 0,00 & 0,00 \\
\hline & $\mathrm{T} 2$ & 0,00 & 0,00 & 0,00 & 0,00 & 0,00 & 0,00 \\
\hline & T3 & 0,00 & 0,00 & 0,00 & 0,00 & 0,00 & 0,00 \\
\hline & T4 & 0,00 & 0,00 & 0,00 & 0,00 & 0,00 & 0,00 \\
\hline & T5 & 0,00 & 0,00 & 0,00 & 0,00 & 0,00 & 0,00 \\
\hline \multirow{5}{*}{$\begin{array}{l}\text { Limpeza manual + } \\
\text { USS c/ enxágue em } \\
\text { água potável }\end{array}$} & T1 & 0,00 & 0,00 & 0,00 & 0,00 & 0,00 & 0,00 \\
\hline & $\mathrm{T} 2$ & 0,00 & 0,00 & 0,00 & 0,00 & 0,00 & 0,00 \\
\hline & T3 & 0,00 & 0,00 & 69,78 & 0,86 & 0,00 & 0,00 \\
\hline & T4 & 0,00 & 0,00 & 0,00 & 0,00 & 0,00 & 0,00 \\
\hline & T5 & 0,00 & 0,00 & 209,33 & 2,58 & 0,00 & 0,00 \\
\hline \multirow{3}{*}{$\begin{array}{l}\text { Limpeza manual + } \\
\text { USS, c/ enxague em } \\
\text { água potável + } \\
\text { enxágue final em } \\
\text { água destilada } \\
\text { esterilizada }\end{array}$} & T1 & 190,95 & 2,36 & 0,00 & 0,00 & 0,00 & 0,00 \\
\hline & $\mathrm{T} 2$ & 0,00 & 0,00 & 0,00 & 0,00 & 0,00 & 0,00 \\
\hline & T3 & 0,00 & 0,00 & 0,00 & 0,00 & 0,00 & 0,00 \\
\hline \multirow{3}{*}{$\begin{array}{c}\text { Controle negativo } \\
\text { (limpeza manual e } \\
\text { enxágue em água } \\
\text { potável) }\end{array}$} & T1 & 0,00 & 0,00 & 0,00 & 0,00 & 0,00 & 0,00 \\
\hline & T2 & 0,00 & 0,00 & 0,00 & 0,00 & 0,00 & 0,00 \\
\hline & T3 & 0,00 & 0,00 & 0,00 & 0,00 & 0,00 & 0,00 \\
\hline \multirow{5}{*}{$\begin{array}{l}\text { Controle negativo } \\
\text { (limpeza manual + } \\
\text { USS c/enxágue em } \\
\text { água potável + } \\
\text { enxágue final em } \\
\text { água destilada } \\
\text { esterilizada) }\end{array}$} & T1 & 0,00 & 0,00 & 0,00 & 0,00 & 0,00 & 0,00 \\
\hline & $\mathrm{T} 2$ & 26,10 & 0,32 & 0,00 & 0,00 & 0,00 & 0,00 \\
\hline & & & & & & & \\
\hline & & & & & & & \\
\hline & T3 & 138,00 & 1,70 & 0,00 & 0,00 & 0,00 & 0,00 \\
\hline
\end{tabular}

Observações: "USS - limpeza com lavadora ultrassônica específica para materiais canulados, com sistema de bombeamento pulsante retrofluxo. Considerou-se como 0 resultados menores que o limite detecção para o teste, não significando necessariamente ausência. 


\section{Apêndice C - Formulário de Registro dos Resultados dos Testes de ESTERILIDADE Do PRÉ-TeSTE}

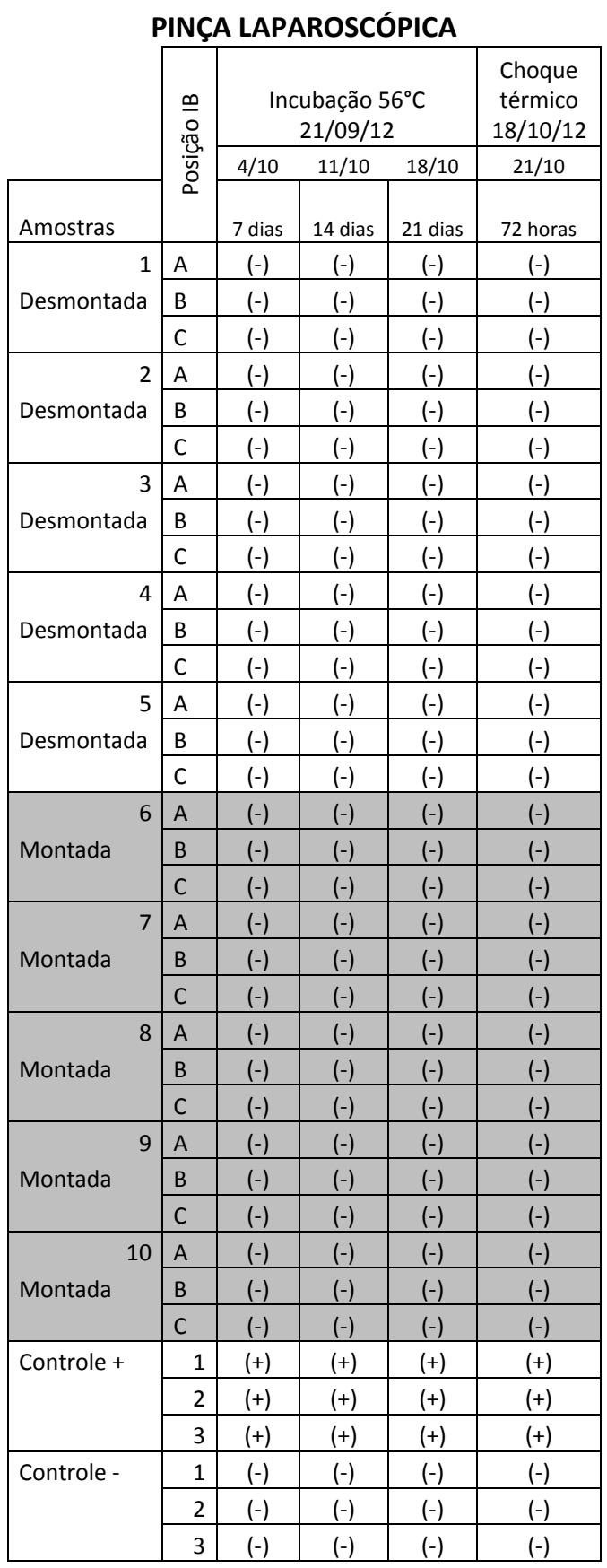

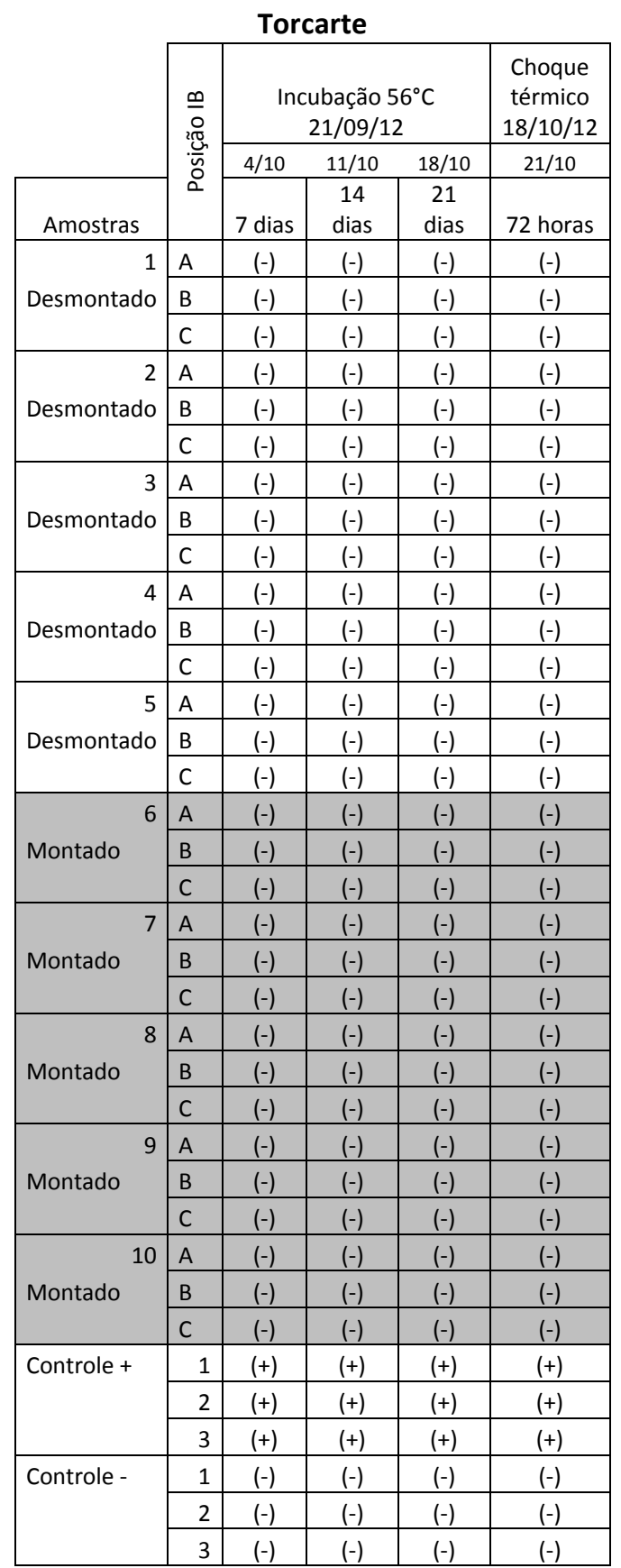



APÊNDICE D - Formulário de Registro dos Resultados dos TeSTes de
ESTERILIDAde COM INSTRUMENTAL LAPAROSCóPICO MONTAdo

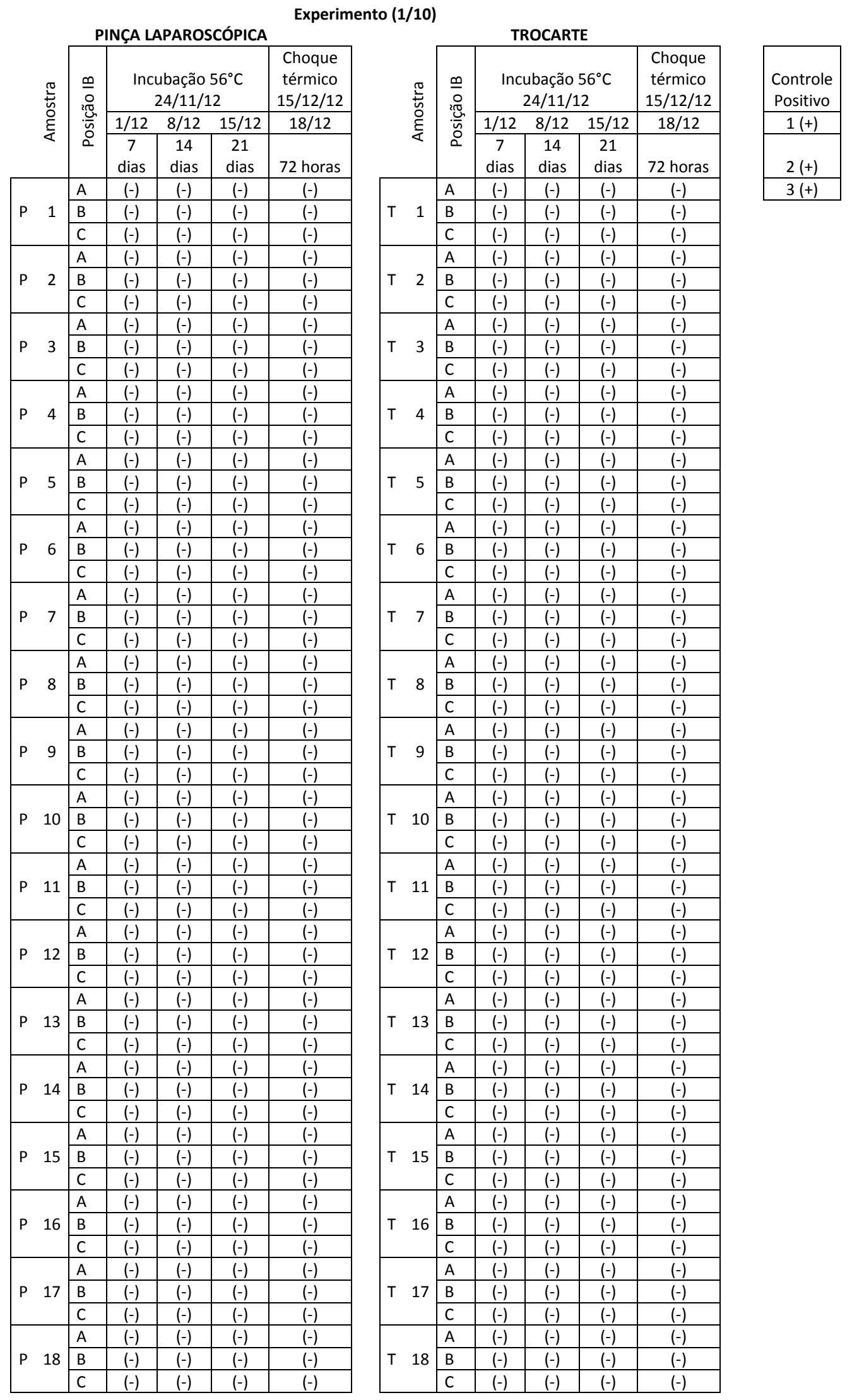


Experimento (2/10)

\begin{tabular}{|c|c|c|c|c|c|c|c|c|c|c|c|c|c|}
\hline \multirow{4}{*}{\multicolumn{2}{|c|}{ }} & \multicolumn{5}{|c|}{ PINÇA LAPAROSCÓPICA } & \multicolumn{7}{|c|}{ TROCARTE } \\
\hline & & \multirow{3}{*}{$\begin{array}{l}\frac{0}{2} \\
\frac{0}{0} \\
\frac{0}{5} \\
0 \\
0\end{array}$} & \multicolumn{3}{|c|}{$\begin{array}{c}\text { Incubação } 56^{\circ} \mathrm{C} \\
25 / 11 / 12\end{array}$} & \begin{tabular}{|c|} 
Choque \\
térmico \\
$16 / 12 / 12$
\end{tabular} & \multirow{3}{*}{\multicolumn{2}{|c|}{ 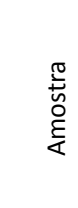 }} & \multirow{3}{*}{ 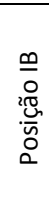 } & \multicolumn{3}{|c|}{$\begin{array}{c}\text { Incubação } 56^{\circ} \mathrm{C} \\
25 / 11 / 12\end{array}$} & \multirow{2}{*}{$\begin{array}{c}\begin{array}{c}\text { Choque } \\
\text { térmico } \\
16 / 12 / 12 \\
19 / 12\end{array}\end{array}$} \\
\hline & & & $2 / 12$ & $9 / 12$ & $16 / 12$ & $19 / 12$ & & & & $2 / 12$ & $9 / 12$ & $16 / 12$ & \\
\hline & & & $\begin{array}{c}7 \\
\text { dias }\end{array}$ & $\begin{array}{c}14 \\
\text { dias }\end{array}$ & $\begin{array}{c}21 \\
\text { dias }\end{array}$ & 72 horas & & & & $\begin{array}{c}7 \\
\text { dias }\end{array}$ & $\begin{array}{c}14 \\
\text { dias }\end{array}$ & $\begin{array}{c}21 \\
\text { dias }\end{array}$ & 72 horas \\
\hline \multirow{3}{*}{$P$} & & A & $(-)$ & $(-)$ & $(-)$ & $(-)$ & \multirow{3}{*}{$\mathrm{T}$} & \multirow{3}{*}{1} & A & $(-)$ & $(-)$ & $(-)$ & $(-)$ \\
\hline & 1 & B & $(-)$ & $(-)$ & $(-)$ & $(-)$ & & & $\mathrm{B}$ & $(-)$ & $(-)$ & $(-)$ & $(-)$ \\
\hline & & C & $(-)$ & $(-)$ & $(-)$ & $(-)$ & & & C & $(-)$ & $(-)$ & $(-)$ & $(-)$ \\
\hline \multirow{3}{*}{ P 2} & & $A$ & $(-)$ & $(-)$ & $(-)$ & $(-)$ & & & $\mathrm{A}$ & $(-)$ & $(-)$ & $(-)$ & $(-)$ \\
\hline & & $B$ & $(-)$ & $(-)$ & $(-)$ & $(-)$ & & 2 & $B$ & $(-)$ & $(-)$ & $(-)$ & $(-)$ \\
\hline & & C & $(-)$ & $(-)$ & $(-)$ & $(-)$ & & & $C$ & $(-)$ & $(-)$ & $(-)$ & $(-)$ \\
\hline & & $\mathrm{A}$ & $(-)$ & $(-)$ & $(-)$ & $(-)$ & & & $A$ & $(-)$ & $(-)$ & $(-)$ & $(-)$ \\
\hline P 3 & 3 & $B$ & $(-)$ & $(-)$ & $(-)$ & $(-)$ & & 3 & $B$ & $(-)$ & $(-)$ & $(-)$ & $(-)$ \\
\hline & & C & $(-)$ & $(-)$ & $(-)$ & $(-)$ & & & $C$ & $(-)$ & $(-)$ & $(-)$ & $(-)$ \\
\hline & & A & $(-)$ & $(-)$ & $(-)$ & $(-)$ & & & A & $(-)$ & $(-)$ & $(-)$ & $(-)$ \\
\hline$P \quad 4$ & 4 & $B$ & $(-)$ & $(-)$ & $(-)$ & $(-)$ & & 4 & B & $(-)$ & $(-)$ & $(-)$ & $(-)$ \\
\hline & & C & $(-)$ & $(-)$ & $(-)$ & $(-)$ & & & $C$ & $(-)$ & $(-)$ & $(-)$ & $(-)$ \\
\hline & & A & $(-)$ & $(-)$ & $(-)$ & $(-)$ & & & A & $(-)$ & $(-)$ & $(-)$ & $(-)$ \\
\hline$P 5$ & 5 & B & $(-)$ & $(-)$ & $(-)$ & $(-)$ & & 5 & $B$ & $(-)$ & $(-)$ & $(-)$ & $(-)$ \\
\hline & & C & $(-)$ & $(-)$ & $(-)$ & $(-)$ & & & $C$ & $(-)$ & $(-)$ & $(-)$ & $(-)$ \\
\hline & & A & $(-)$ & $(-)$ & $(-)$ & $(-)$ & & & A & $(-)$ & $(-)$ & $(-)$ & $(-)$ \\
\hline$P \quad 6$ & 5 & B & $(-)$ & $(-)$ & $(-)$ & $(-)$ & & 6 & $B$ & $(-)$ & $(-)$ & $(-)$ & $(-)$ \\
\hline & & C & $(-)$ & $(-)$ & $(-)$ & $(-)$ & & & $C$ & $(-)$ & $(-)$ & $(-)$ & $(-)$ \\
\hline & & A & $(-)$ & $(-)$ & $(-)$ & $(-)$ & & & $A$ & $(-)$ & $(-)$ & $(-)$ & $(-)$ \\
\hline$P 7$ & 7 & B & $(-)$ & $(-)$ & $(-)$ & $(-)$ & & 7 & $B$ & $(-)$ & $(-)$ & $(-)$ & $(-)$ \\
\hline & & C & $(-)$ & $(-)$ & $(-)$ & $(-)$ & & & $C$ & $(-)$ & $(-)$ & $(-)$ & $(-)$ \\
\hline & & A & $(-)$ & $(-)$ & $(-)$ & $(-)$ & & & $A$ & $(-)$ & $(-)$ & $(-)$ & $(-)$ \\
\hline P 8 & 3 & B & $(-)$ & $(-)$ & $(-)$ & $(-)$ & & 8 & $B$ & $(-)$ & $(-)$ & $(-)$ & $(-)$ \\
\hline & & $C$ & $(-)$ & $(-)$ & $(-)$ & $(-)$ & & & $C$ & $(-)$ & $(-)$ & $(-)$ & $(-)$ \\
\hline & & $A$ & $(-)$ & $(-)$ & $(-)$ & $(-)$ & & & $A$ & $(-)$ & $(-)$ & $(-)$ & $(-)$ \\
\hline$P \quad g$ & & $\mathrm{~B}$ & $(-)$ & $(-)$ & $(-)$ & $(-)$ & & 9 & $\mathrm{~B}$ & $(-)$ & $(-)$ & $(-)$ & $(-)$ \\
\hline & & $C$ & $(-)$ & $(-)$ & $(-)$ & $(-)$ & & & $C$ & $(-)$ & $(-)$ & $(-)$ & $(-)$ \\
\hline & & A & $(-)$ & $(-)$ & $(-)$ & $(-)$ & & & $\mathrm{A}$ & $(-)$ & $(-)$ & $(-)$ & $(-)$ \\
\hline P 1 & & B & $(-)$ & $(-)$ & $(-)$ & $(-)$ & & 10 & $B$ & $(-)$ & $(-)$ & $(-)$ & $(-)$ \\
\hline & & C & $(-)$ & $(-)$ & $(-)$ & $(-)$ & & & $C$ & $(-)$ & $(-)$ & $(-)$ & $(-)$ \\
\hline & & $A$ & $(-)$ & $(-)$ & $(-)$ & $(-)$ & & & A & $(-)$ & $(-)$ & $(-)$ & $(-)$ \\
\hline $\begin{array}{ll}P & 1\end{array}$ & 1 & B & $(-)$ & $(-)$ & $(-)$ & $(-)$ & & 11 & B & $(-)$ & $(-)$ & $(-)$ & $(-)$ \\
\hline & & C & $(-)$ & $(-)$ & $(-)$ & $(-)$ & & & C & $(-)$ & $(-)$ & $(-)$ & $(-)$ \\
\hline & & A & $(-)$ & $(-)$ & $(-)$ & $(-)$ & & & A & $(-)$ & $(-)$ & $(-)$ & $(-)$ \\
\hline $\begin{array}{lll}P & 1\end{array}$ & 2 & $B$ & $(-)$ & $(-)$ & $(-)$ & $(-)$ & & 12 & B & $(-)$ & $(-)$ & $(-)$ & $(-)$ \\
\hline & & $C$ & $(-)$ & $(-)$ & $(-)$ & $(-)$ & & & $C$ & $(-)$ & $(-)$ & $(-)$ & $(-)$ \\
\hline & & $A$ & $(-)$ & $(-)$ & $(-)$ & $(-)$ & & & $A$ & $(-)$ & $(-)$ & $(-)$ & $(-)$ \\
\hline $\begin{array}{ll}P & 1\end{array}$ & 3 & B & $(-)$ & $(-)$ & $(-)$ & $(-)$ & & 13 & B & $(-)$ & $(-)$ & $(-)$ & $(-)$ \\
\hline & & $C$ & $(-)$ & $(-)$ & $(-)$ & $(-)$ & & & $C$ & $(-)$ & $(-)$ & $(-)$ & $(-)$ \\
\hline & & $A$ & $(-)$ & $(-)$ & $(-)$ & $(-)$ & & & $A$ & $(-)$ & $(-)$ & $(-)$ & $(-)$ \\
\hline $\begin{array}{lll}P & 1\end{array}$ & 4 & B & $(-)$ & $(-)$ & $(-)$ & $(-)$ & & 14 & B & $(-)$ & $(-)$ & $(-)$ & $(-)$ \\
\hline & & $C$ & $(-)$ & $(-)$ & $(-)$ & $(-)$ & & & $C$ & $(-)$ & $(-)$ & $(-)$ & $(-)$ \\
\hline & & $A$ & $(-)$ & $(-)$ & $(-)$ & $(-)$ & & & $A$ & $(-)$ & $(-)$ & $(-)$ & $(-)$ \\
\hline $\begin{array}{ll}P & 1\end{array}$ & 5 & $B$ & $(-)$ & $(-)$ & $(-)$ & $(-)$ & & 15 & B & $(-)$ & $(-)$ & $(-)$ & $(-)$ \\
\hline & & $C$ & $(-)$ & $(-)$ & $(-)$ & $(-)$ & & & C & $(-)$ & $(-)$ & $(-)$ & $(-)$ \\
\hline & & $A$ & $(-)$ & $(-)$ & $(-)$ & $(-)$ & & & $A$ & $(-)$ & $(-)$ & $(-)$ & $(-)$ \\
\hline $\begin{array}{ll}P & 1\end{array}$ & 6 & B & $(-)$ & $(-)$ & $(-)$ & $(-)$ & & 16 & B & $(-)$ & $(-)$ & $(-)$ & $(-)$ \\
\hline & & C & $(-)$ & $(-)$ & $(-)$ & $(-)$ & & & C & $(-)$ & $(-)$ & $(-)$ & $(-)$ \\
\hline & & $A$ & $(-)$ & $(-)$ & $(-)$ & $(-)$ & & & $A$ & $(-)$ & $(-)$ & $(-)$ & $(-)$ \\
\hline $\begin{array}{ll}P & 1\end{array}$ & 7 & B & $(-)$ & $(-)$ & $(-)$ & $(-)$ & & 17 & B & $(-)$ & $(-)$ & $(-)$ & $(-)$ \\
\hline & & C & $(-)$ & $(-)$ & $(-)$ & $(-)$ & & & C & $(-)$ & $(-)$ & $(-)$ & $(-)$ \\
\hline & & $A$ & $(-)$ & $(-)$ & $(-)$ & $(-)$ & & & $A$ & $(-)$ & $(-)$ & $(-)$ & $(-)$ \\
\hline $\begin{array}{ll}P & 1\end{array}$ & 8 & B & $(-)$ & $(-)$ & $(-)$ & $(-)$ & & 18 & B & $(-)$ & $(-)$ & $(-)$ & $(-)$ \\
\hline & & C & $(-)$ & $(-)$ & $(-)$ & $(-)$ & & & C & $(-)$ & $(-)$ & $(-)$ & $(-)$ \\
\hline
\end{tabular}


Apêndices 96

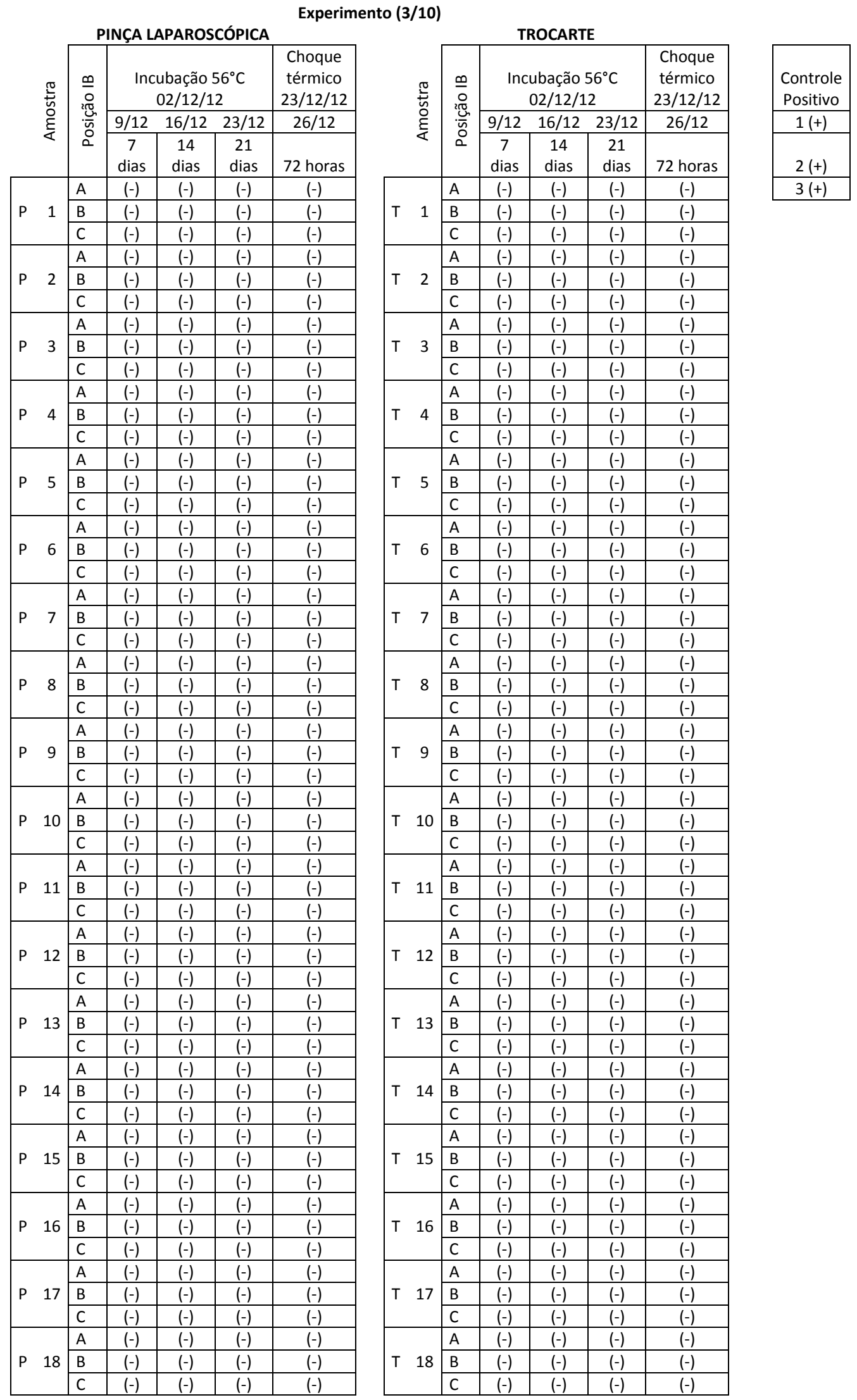




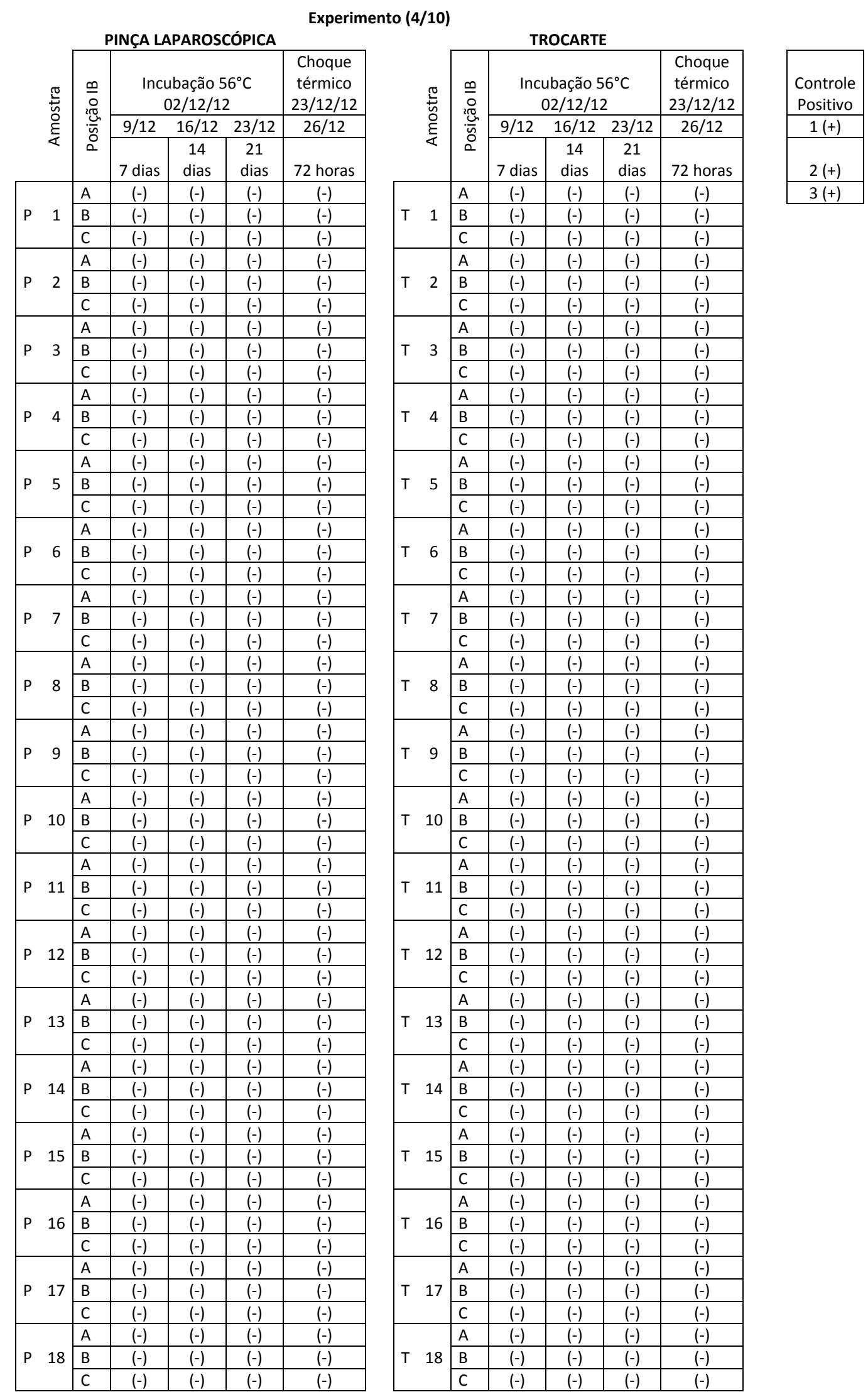


Apêndices 98

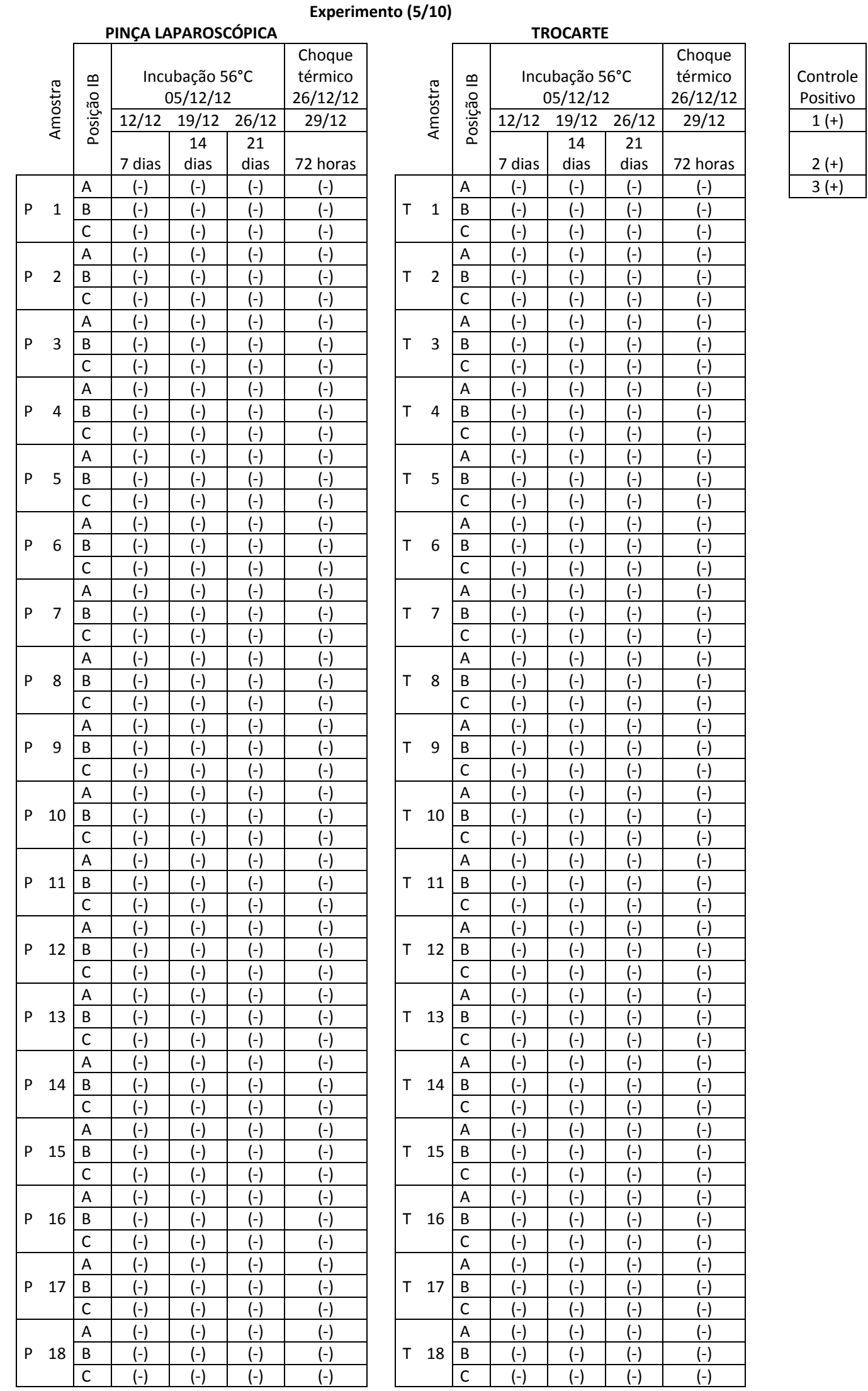




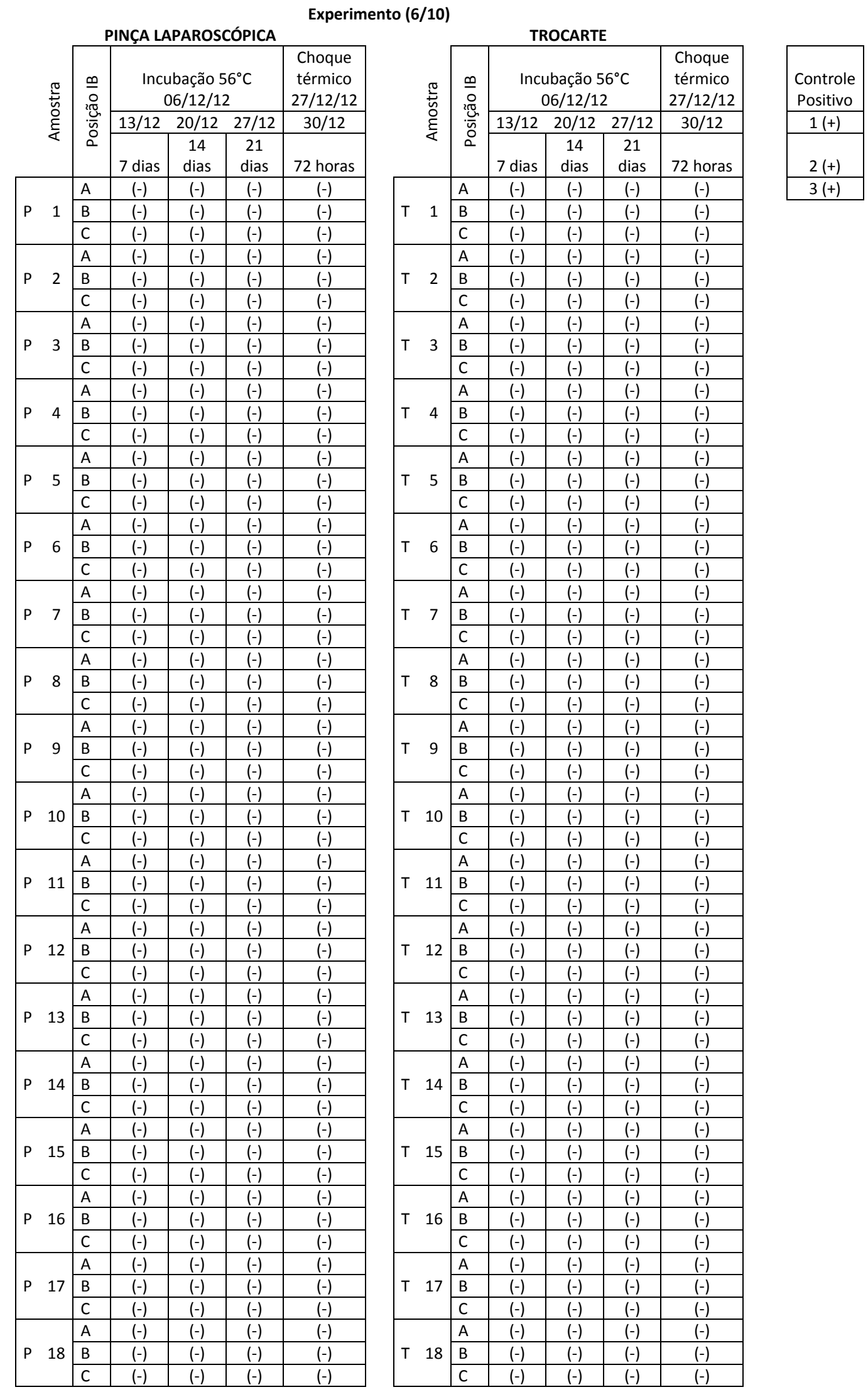




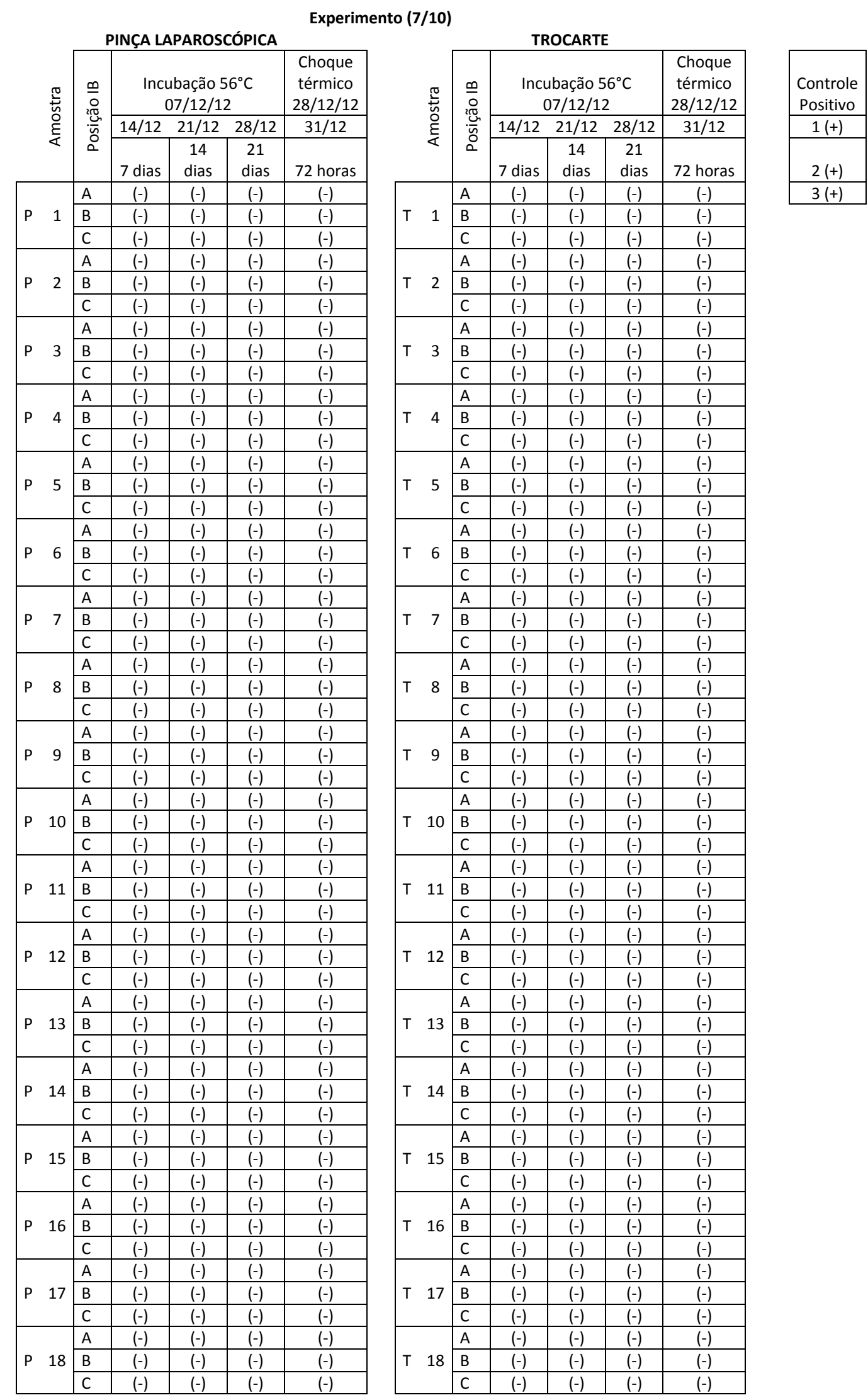




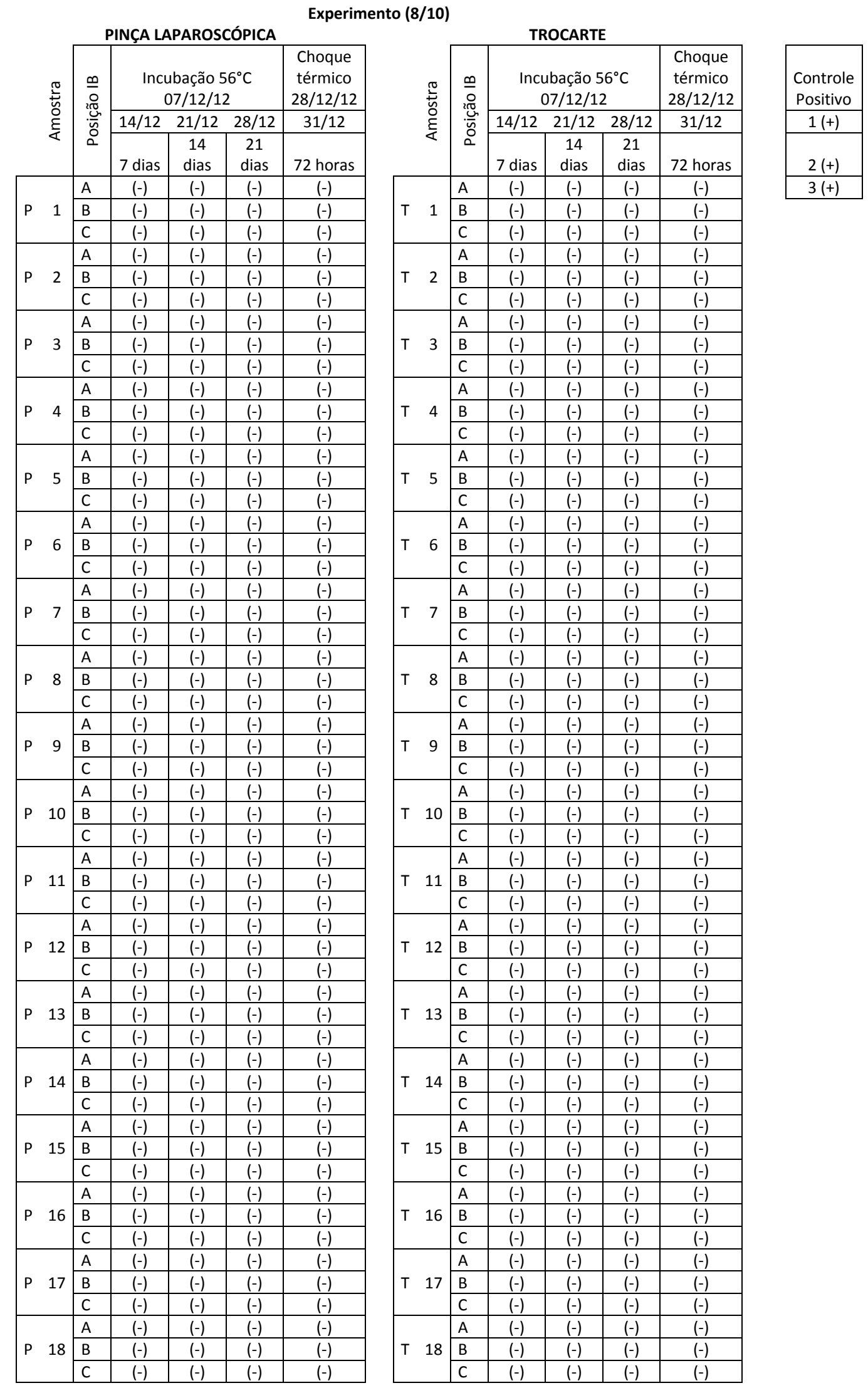




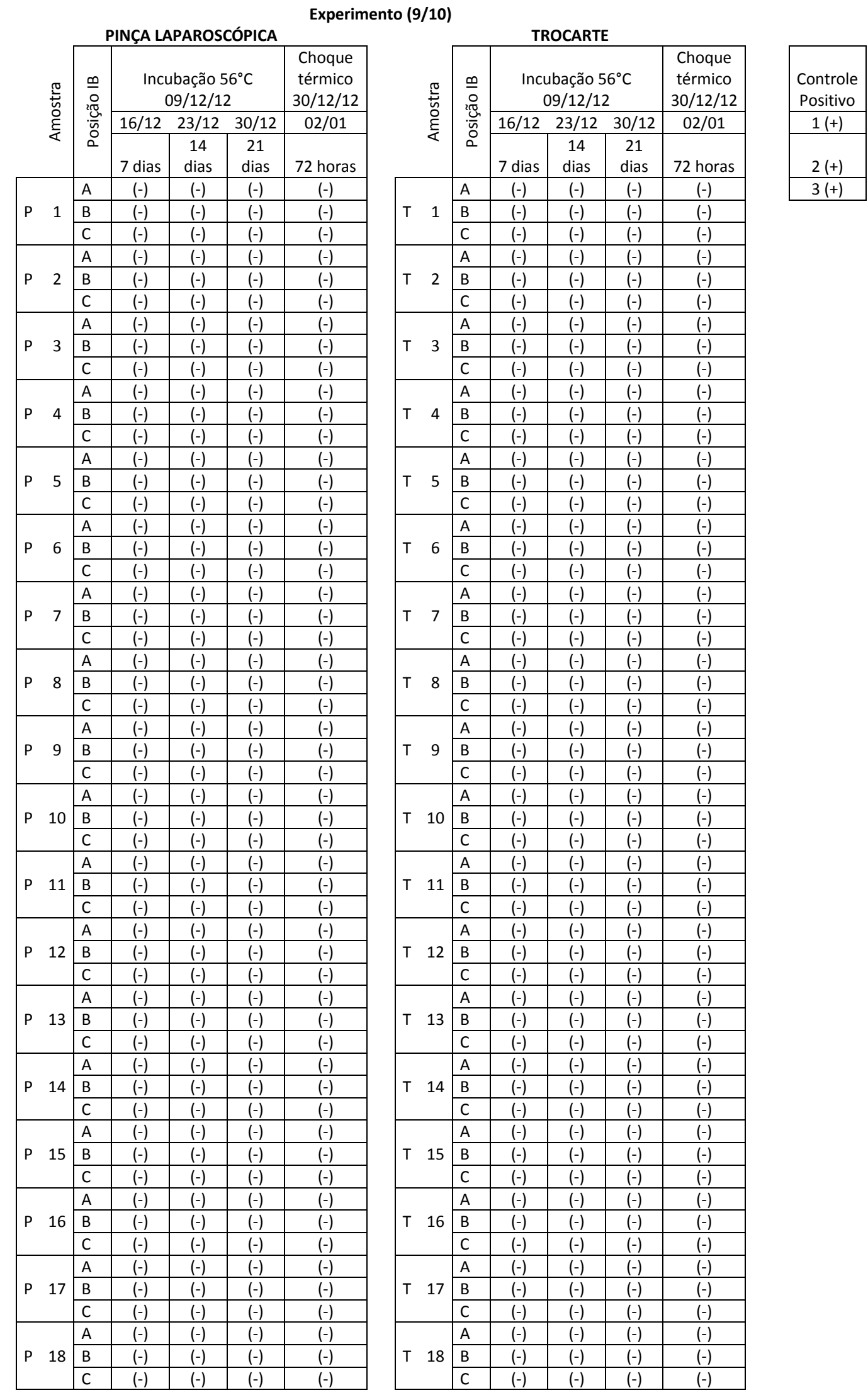




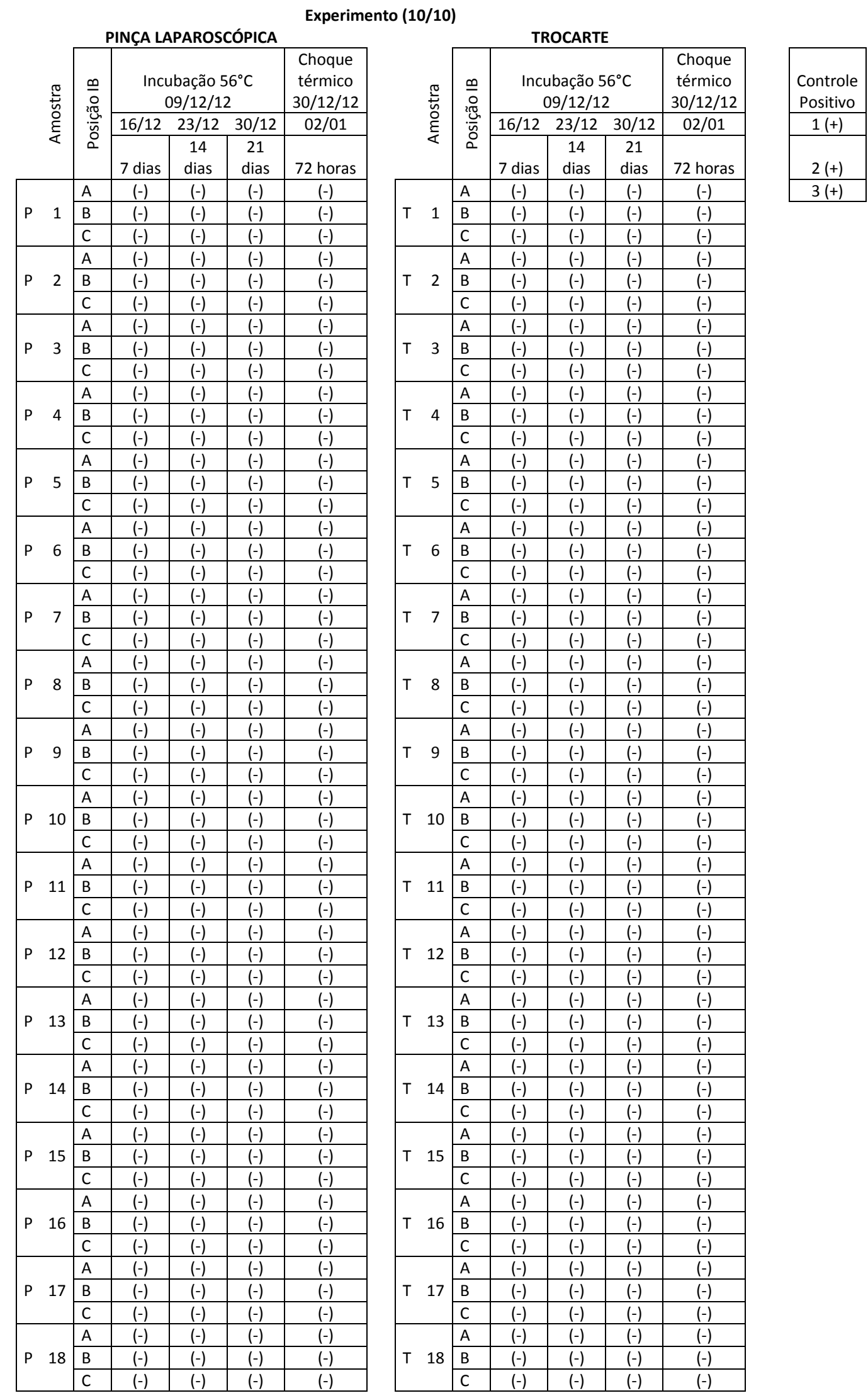


Anexos 
ANEXo 1 - CÁlCUlo da Área da SUPERFície do InSTRUMental

LAPAROSCÓPICO ${ }^{11}$

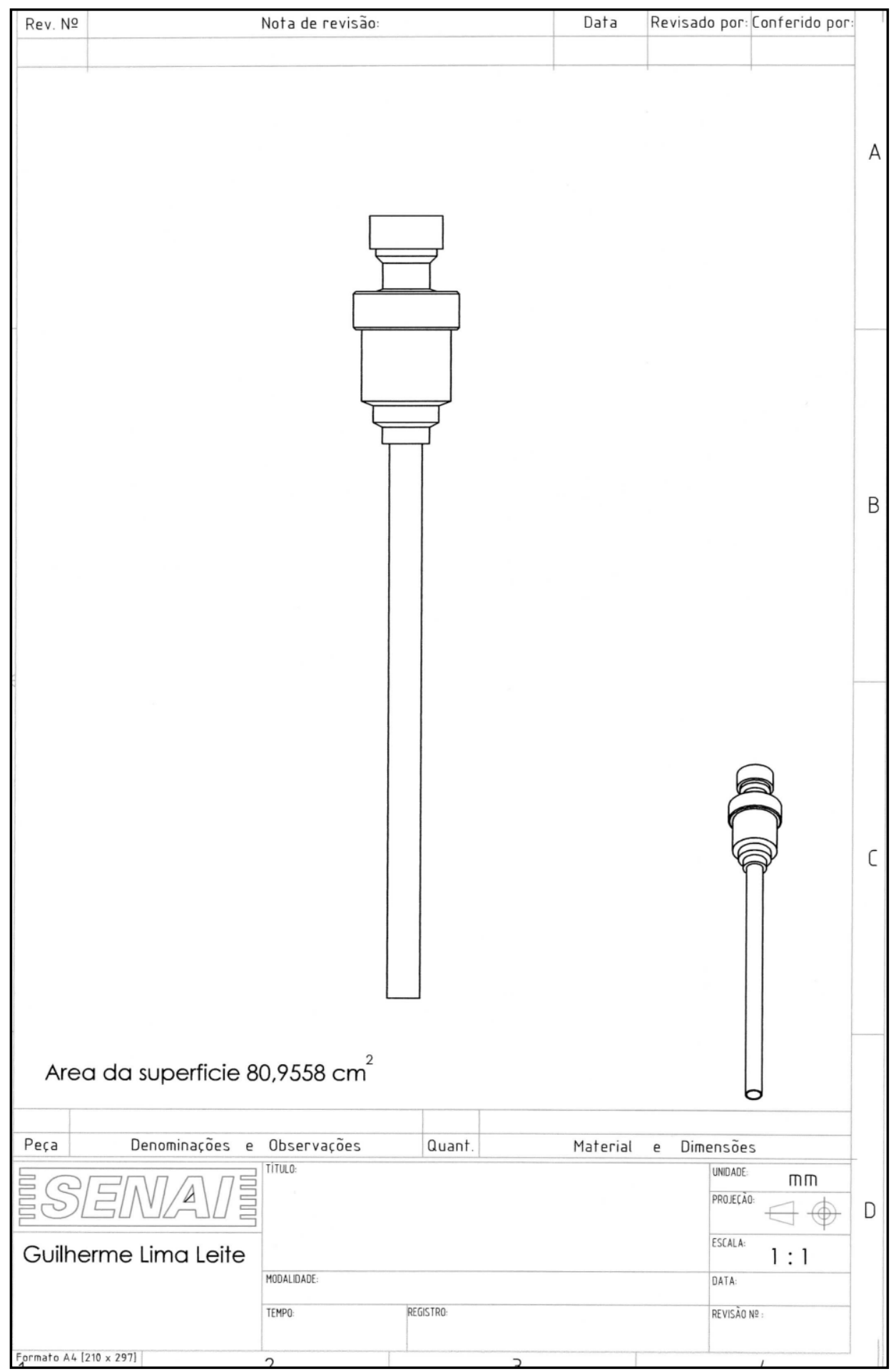

${ }^{11}$ Software Solidworks, versão 2012-2013. Professores responsáveis: Valter Roberto Serafim e José Roberto Melo. 


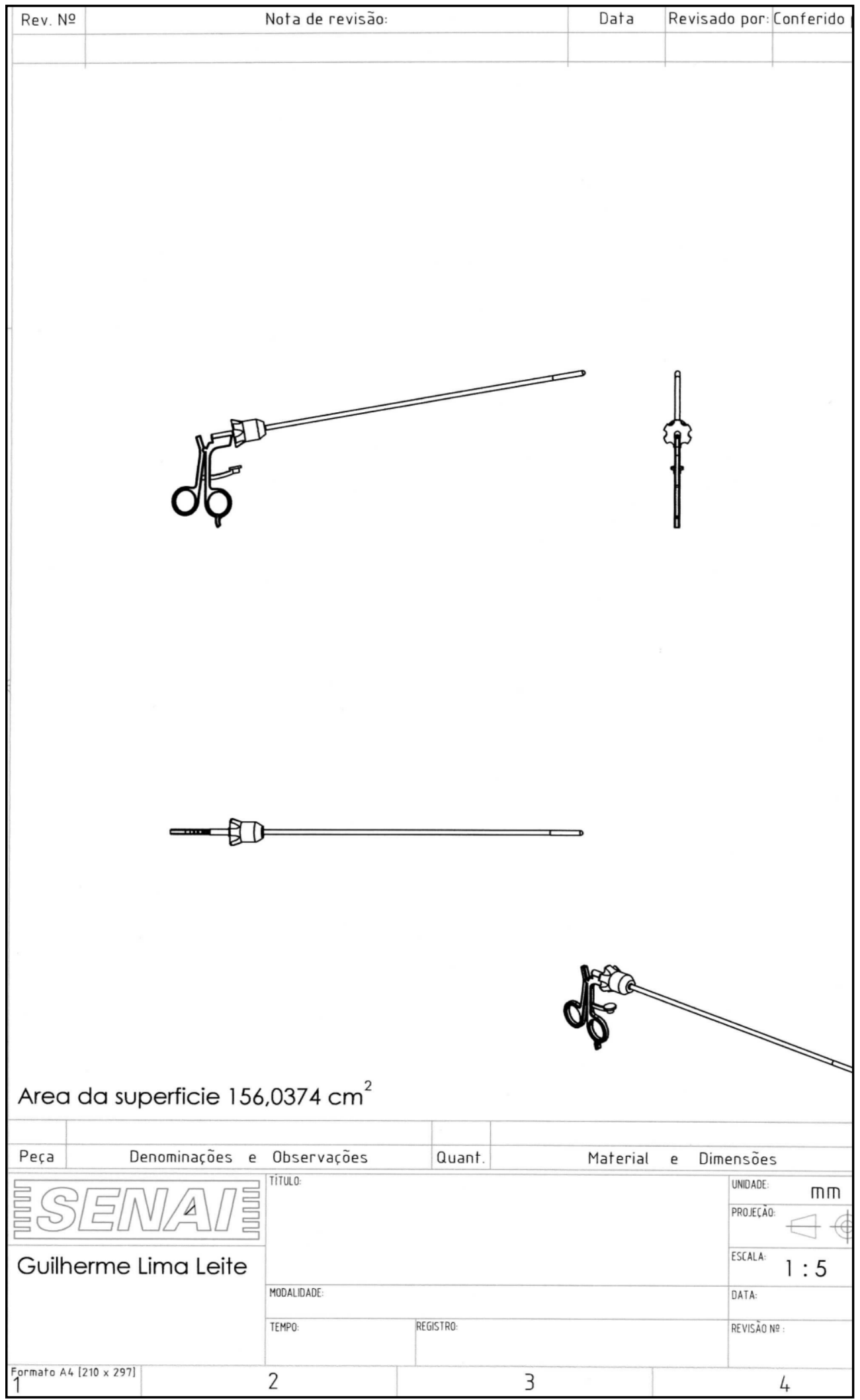




\section{ANEXO 2 - CiCLOS DE ESTERILIZAÇÃO DO INSTRUMENTAL LAPAROSCÓPICO}

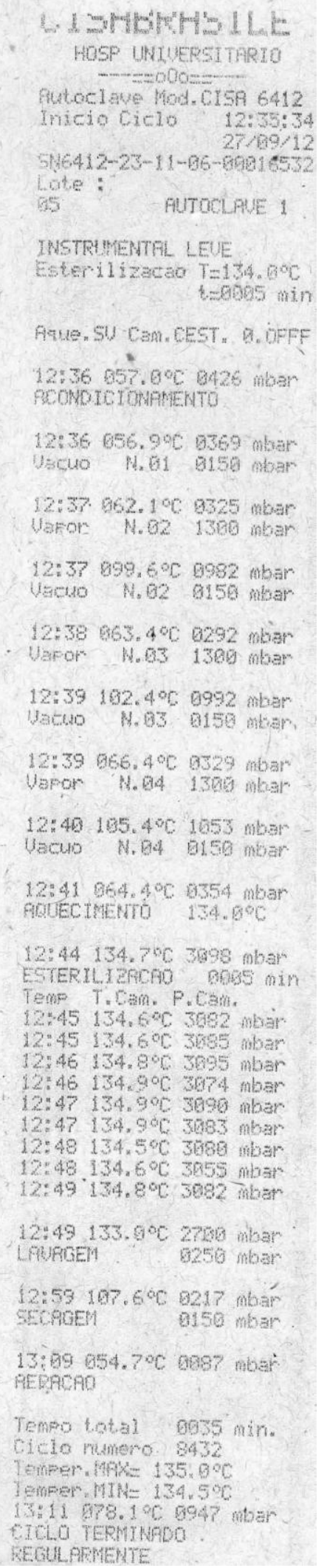

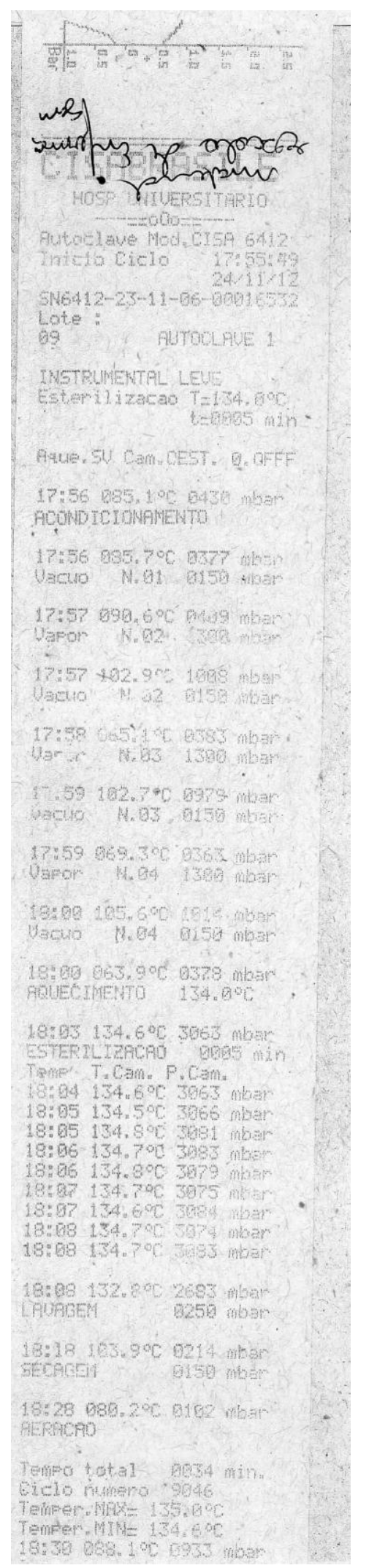

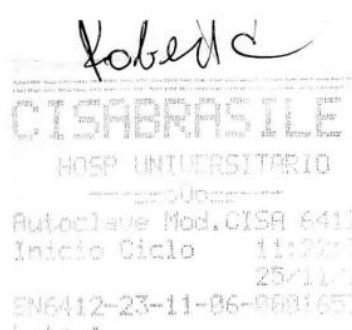

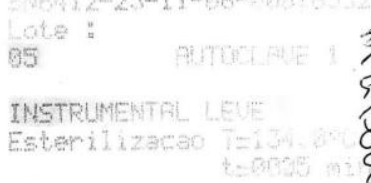

3
है
है
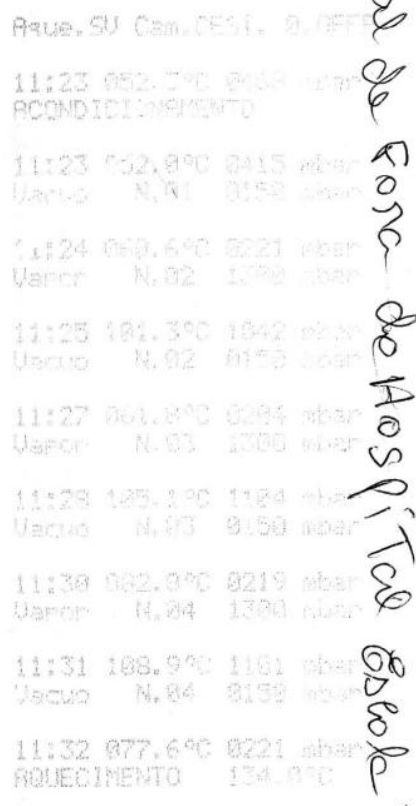

11: 1 की

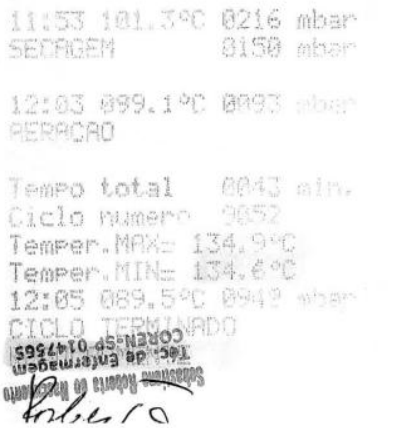




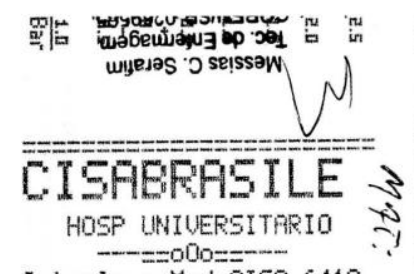

Rutoclave Mod. CISA 6412 Inicio Ciclo 07:42:07?

5N6412-23-11-66-00616532 \& Lote : AUTOCLAUE 1 i

INSTRUMENTRL LEUE

Esterilizacao $T=134.0^{\circ} \mathrm{C}$ $t=0005 \mathrm{~min}$

Aque. SU Cam.CEST. O. OFFF

97:42 $066.6^{\circ} \mathrm{C}$ 0444 mbar ACONDICIONAMENTO

07:42 066.7० 0391 mbar Uacuo N.01 $0150 \mathrm{mbar}$

$07: 43070.4^{\circ} \mathrm{C} 0266 \mathrm{mbar}$ Uapor \$. 621300 mbar

$07: 45111.3^{\circ} \mathrm{C} \quad 1113$ mbar Uacuo N. 02 0150 mbar

07:47 090.9 $9^{\circ} \mathrm{C} 0183$ mbar Uapor $N .631300$ mbar

$07: 49114.3^{\circ} \mathrm{C} 1181 \mathrm{mbar}$ Uacuo N.03 6150 mbar

07:51 097.4\% $0182 \mathrm{mbar}$ Uafor N.04 1300 mbar

97:53 115.6\% 1177 mbar Uacuo N.04 0150 mbar

07:55 109.9\%: 0183 mbar RQUECIMENTO $134.9^{\circ} \mathrm{C}$

08:02 134, 5063059 mbar ESTERIYIEACAO $0005 \mathrm{~min}$

Temp T. Cam. F.Cam.

68:03 134,892 3065 mbar 68:03 154.8\% 3036 mbar 68:04 134.8 $8^{\circ} \mathrm{C} 3011$ mbar $08: 04134.6^{\circ} \mathrm{C} 3698$ mbar $\mathrm{CP}_{4}$ 08:05 $134.8^{\circ} \mathrm{C} 3018$ mbar 68:05 $134.7^{\circ} \mathrm{C} 2996 \mathrm{mbar}$ $08: 06 \quad 134.7^{\circ} \mathrm{C} 3019 \mathrm{mbar}$ 08:06 $134.7^{\circ} \mathrm{C} 2995$ mbar 68:07 134.6\% 3029 mbar

68:07 $133.0^{\circ} \mathrm{C} 2739 \mathrm{mbar}$ LAUAGEM 0250 mbar

08:18 $104.1^{\circ} \mathrm{C} 0226 \mathrm{mbar}^{2}$ SECAOEM 0150 mbar

08:28 099.0\% 0685 mbar AERACAO

Tempo total $0049 \mathrm{~min}$. Ciclo numero 9124 Temper. MAK $=134.8^{\circ} \mathrm{C}$

TempqT.MIMA $134.6^{\circ} \mathrm{C}$ $08 \% 31092.5$ C 9937 mbar CXCLO TERMIMAOOO

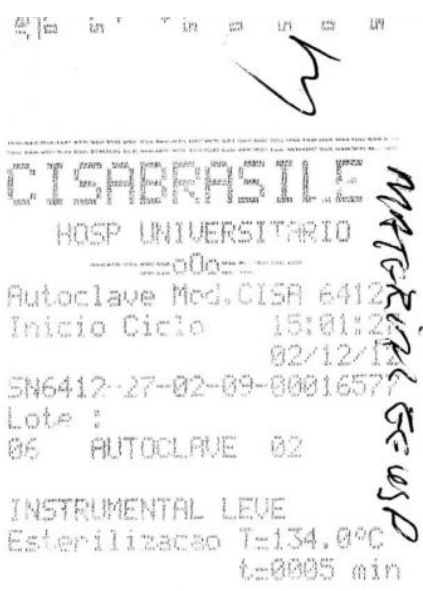

Pince. S1) Can.CEST. D. OFFF

15:01 069.70\% 0499 mbar ACOHDICIONAMENTO

\section{5:82 665.5\% 9449 mbat}

jacus M. 91 a150 mbar.

15.95675 .409 .9257 mar

uapor 4.921396 nbar

15.64105 .8001036 notar

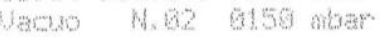

15.86 977. 308 0225 mbar

उson W, 23 1389 mbar

$35: 67$ 111. $30 \mathrm{c} 1119 \mathrm{mbar}$

पacuo M. 35 atso mos

15.93 986. 190.9224 mbar

13mor N.94 $1398 \mathrm{mbar}$

$25: 69113.90 \mathrm{C} 1139$ mbat

पacuo M. M4 Biso mbar

15:11 999. 405 9233 mbar

AQUEDMENTO $134.9 \%$

$45 \times 19 \quad 134,700.3196$ mbar

GSTERLTPFOO 6095 min

Temp T.Can. P.Can.

$15: 19$ 134. $90 \mathrm{c}$ 3.65 mbar

$15.20134 .89 \mathrm{c} .3195$ mbar

$15 \times 26134.70 \mathrm{C} .3182 \mathrm{mbar}$

$15=21$ 134. $90.3192 \mathrm{mbar}$

$15: 21134.900 .3199$ mbar

$15: 22,134.70 \mathrm{C} 3184$ mbar

$15: 22+34.70 \mathrm{C} 3184 \mathrm{~m}$ mar

$15.23 \quad 134.79 \mathrm{C} \cdot 3196 \mathrm{mbar}$

$15=23 \quad 134,60 \mathrm{c} 3189 \mathrm{~g}$ m

$15 \times 24133,30 \mathrm{C} 2995$ mbar

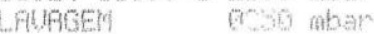

$15: 36 \quad 197.3^{\circ}, 0239$ mba

SECAGEM 8150 nban

$15: 46955.100$ 9062 mbam PERATH

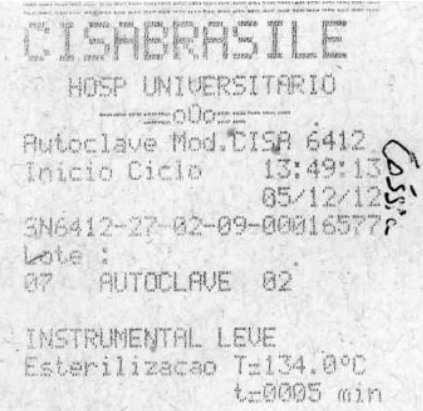

Aque. SU Cam CEST. 9. OFFF

$13: 49073 \times 8^{\circ} \mathrm{C} 0489$ mbar * RCOWDICIONAMENTO

$13: 49$ a72, 700 a 0443 -nbar 3 Wacto N.61 0150 mbar कै 13.51 982.505 a331 mbat है Wapor 14.621380 mbark

$13: 52099.900 \quad 1627$ mibam \& Jacto $M .82-9159$ mbak

$13: 53866.90 \mathrm{0} .0322$ mbar है

Vapor $N .03$ 1380 mbar $\frac{\delta}{5}$

13.53 .105 .995 .9971 mbas agcug N.83 9150 mbar $\frac{R}{2}$

$135.54671 .390,8345$ mbar

Uaper Wa 04 1300 mbar

$13: 55104.9000996 \mathrm{~mm}$ Hewio M.94 $815 a$ mbar

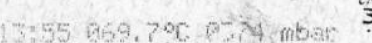
FGIEENEMTO $134.09 \mathrm{C}$

14:91 $134.3^{\circ} \mathrm{C} 3190 \mathrm{mbar}$ ETERII IXTAO 0955 min Temp F.Cain, P. bant

$14: 52134.800 .3184$ mber

$14: 82$ 134.900 3198 mbar

$14: 93 \quad 134.906 \quad 3183 \mathrm{mb}:$

$14: 93134,7063183$ mbat or

$14504134.39 \mathrm{c} 3186$ mbiar

$14: 34134.70 \mathrm{c} 3179$ mbar

$14: 95134.900 \cdot 3212$ mbar

$145155135.00 \mathrm{c} 3222 \mathrm{mbar}$

$14: 96134,700 \mathrm{C} 3182$ nbar

$14,66 \quad 133.09 \mathrm{C} 2794 \mathrm{mbar}$

GPOAOEH $\quad 6250$ mbar

14:17 $114.90 \mathrm{C} 0222$ mbar ECPIEH $9150 \mathrm{mba}$

$14: 27070.700 .0093$ mbar PESTCPO

Tomen total $6046 \mathrm{~min}$

Qith numern 9472

Temper. $M A N=135,0 \%$

Temper. MIH $=134,6 \%$

$14: 29$ 875.000 0938 mbat

CICLO TERMINFDO

PELULRRMEUTE

$\therefore 48$

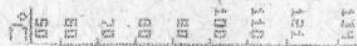




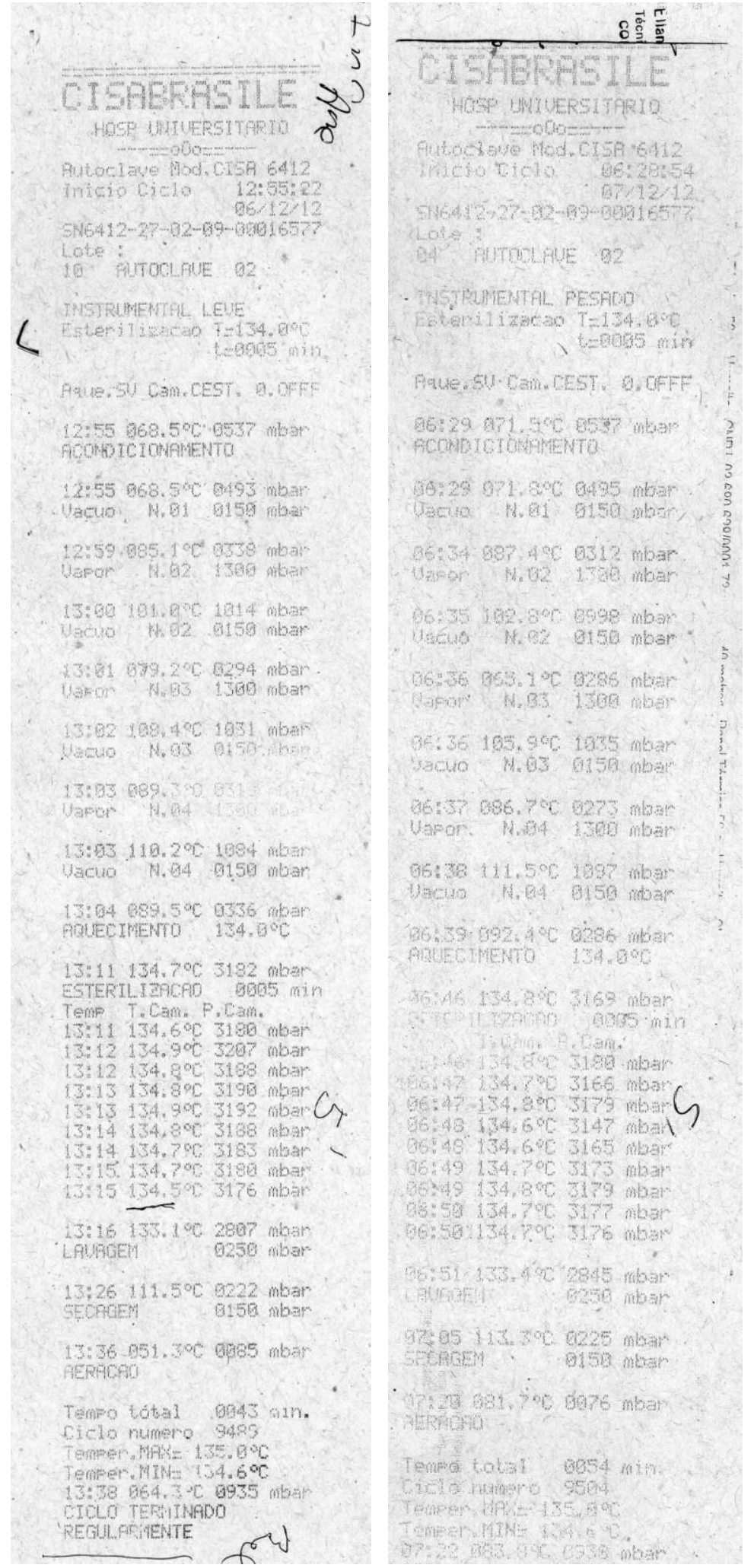

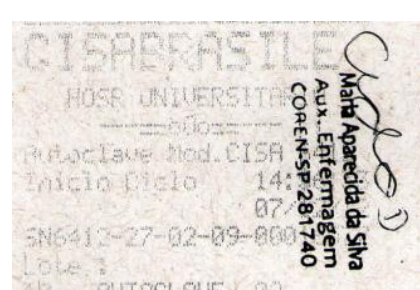

46. AUTOCL GUE 02

INSTRUMENTH PESAOO 0

beterilizecos $7=104,39$

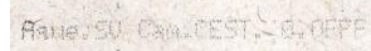

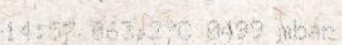

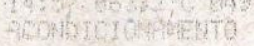

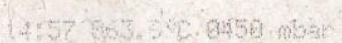

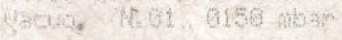

14t5s api.sog 0201 mber

(4) Mom N.92 - 1360 nbat

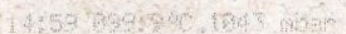

Weno hith 0250 minge

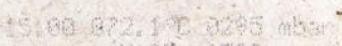

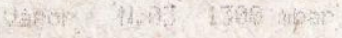

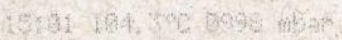

Nach N.43 9159 merar

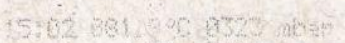

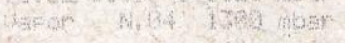

$35: 92$ 135. 100 1830 what

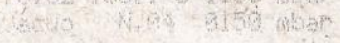

$15.65 \cdot 27.206 \cdot 0055$ matat

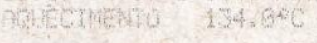

$15.53^{3} 134.96 \mathrm{c}, 390$ mbar

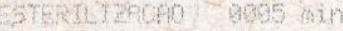

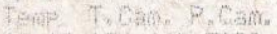

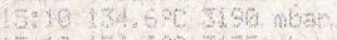

$15: 19144.690 \quad 3175$ mbat:

15:11 134.900 819 mban

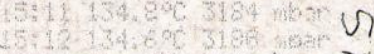

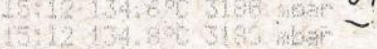

$1502313+9007106 \mathrm{mb}=$

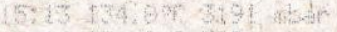

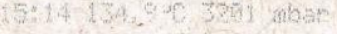

i5:14 t32,800 2792 mbar

Catmost 9250 mbar

$15: 20115,660$. 9220 mbar secherel gt5o mbar

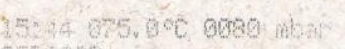
artione

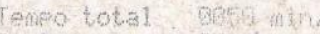
Ciclo numere 9518

fenper MhX = 185,600

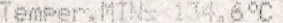

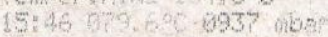

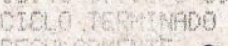




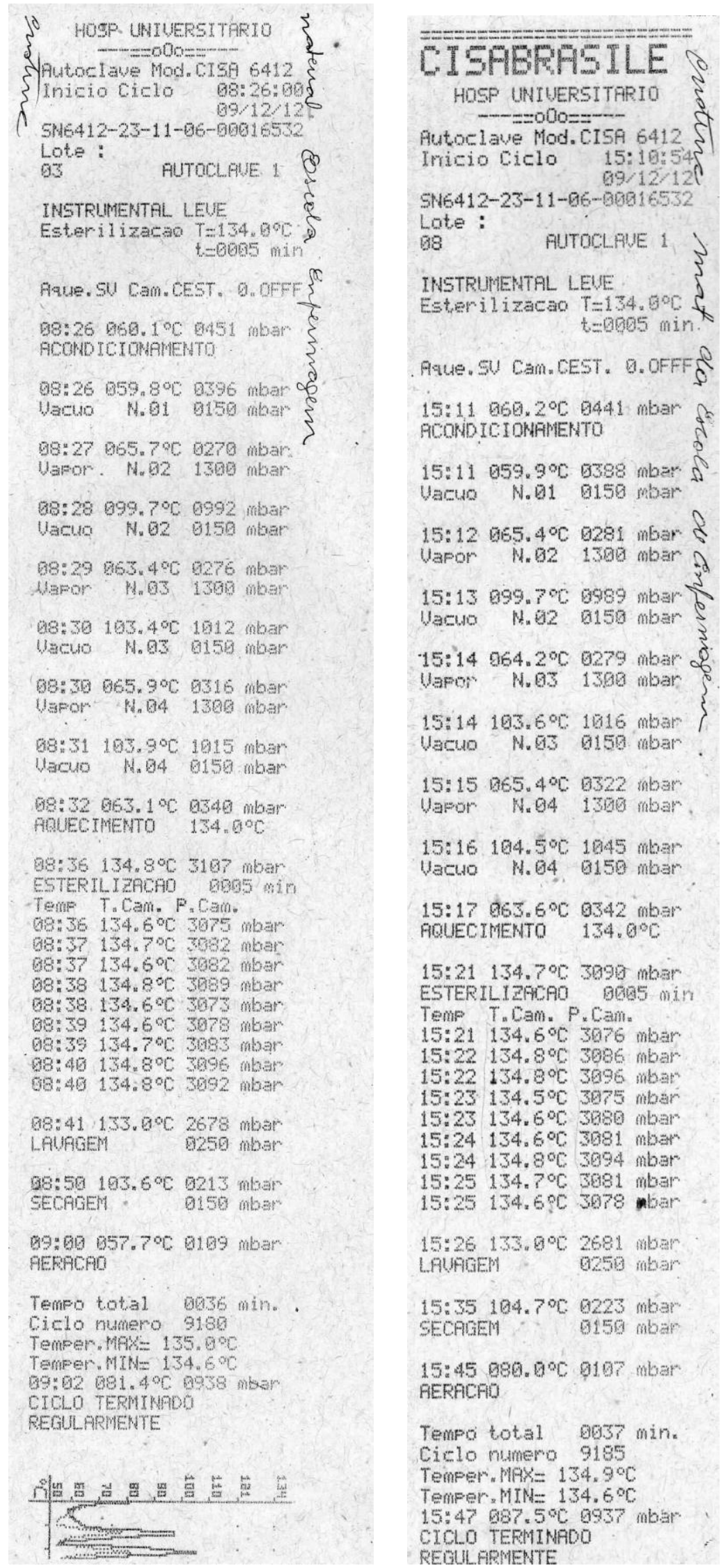




\section{Anexo 3 - Ciclos de Esterilização dos Meios de Cultura}

\begin{tabular}{|c|c|}
\hline $\begin{array}{l}\text { Ver }= \\
\text { Cyc: } 4- \\
\text { Ster T } \\
\text { Ster t } \\
\text { Dry t } \\
12 / 11 /\end{array}$ & $\begin{array}{l}\text { abootn1 } \\
\text { iquids } \\
\text { mp: }{ }^{1} 22^{\circ} \mathrm{C} \\
\text { me:020 min } \\
\text { me:000min } \\
012 \quad 15: 02: 16\end{array}$ \\
\hline W00:00 & $040.3^{\circ} \mathrm{C} 092.0 \mathrm{~K}$ \\
\hline 35 & $043.1^{\circ} \mathrm{C} 092.3 \mathrm{k}$ \\
\hline$: 35$ & $061.6^{\circ} \mathrm{C} 095.8 \mathrm{k}$ \\
\hline $11: 35$ & $091.2^{\circ} \mathrm{C} \quad 108.4 \mathrm{k}$ \\
\hline $6: 35$ & $107.5^{\circ} \mathrm{C} 158.1 \mathrm{k}$ \\
\hline $1: 35$ & $120.0^{\circ} \mathrm{C} 216.9 \mathrm{k}$ \\
\hline $24: 26$ & $122.2^{\circ} \mathrm{C} 228.1 \mathrm{k}$ \\
\hline$S 25: 26$ & $123.1^{\circ} \mathrm{C} 232.4 \mathrm{k}$ \\
\hline$S 26: 26$ & $122.5^{\circ} \mathrm{C} 226.2 \mathrm{k}$ \\
\hline$S 27: 26$ & $122.5^{\circ} \mathrm{C} 229.5 \mathrm{k}$ \\
\hline$\$ 28: 26$ & $123.1^{\circ} \mathrm{C} 229.3 \mathrm{k}$ \\
\hline 6 & $122.3^{\circ} \mathrm{C} 223.0 \mathrm{k}$ \\
\hline$\$ 30: 26$ & $122.8^{\circ} \mathrm{C} 229.8 \mathrm{k}$ \\
\hline$\$ 31: 26$ & $123.1^{\circ} \mathrm{C} 226.8 \mathrm{k}$ \\
\hline S32:26 & $122.2^{\circ} \mathrm{C} 220.5 \mathrm{k}$ \\
\hline S33:26 & $123.0^{\circ} \mathrm{C} 228.4 \mathrm{k}$ \\
\hline$\$ 34: 26$ & $123.0^{\circ} \mathrm{C} 224.8 \mathrm{~K}$ \\
\hline$\$ 35: 26$ & $122.3^{\circ} \mathrm{C} 219.0 \mathrm{~K}$ \\
\hline S36:26 & $123.0^{\circ} \mathrm{C} 226.1 \mathrm{k}$ \\
\hline$\$ 37: 26$ & $123.0^{\circ} \mathrm{C} 222.6 \mathrm{k}$ \\
\hline $538: 26$ & $122.1^{\circ} \mathrm{C} 218.8 \mathrm{k}$ \\
\hline$\$ 39: 26$ & $123.3^{\circ} \mathrm{C} 226.1 \mathrm{k}$ \\
\hline $540: 26$ & $122.9^{\circ} \mathrm{C} 221.3 \mathrm{k}$ \\
\hline$\$ 41: 2$ & $122.1^{\circ} \mathrm{C} 217.5 \mathrm{k}$ \\
\hline$\$ 42: 2$ & $123.2^{\circ} \mathrm{C} 225.2 \mathrm{k}$ \\
\hline$\$ 43: 2$ & $123.0^{\circ} \mathrm{C} 221.2 \mathrm{k}$ \\
\hline & $215.7 k$ \\
\hline & 095. \\
\hline
\end{tabular}

Cycle ended Load number: 0179 12/11/2012 16:26:00 Operator: Autoclave: 1
Ver $=$ Lab0oTn1

Cyc: 4-Liquids

Ster Temp: $122^{\circ} \mathrm{C}$

Ster time:020min

Dry time:000min

12/11/2012 16:41:42

Woo:00 $045.0^{\circ} \mathrm{C} \quad 092.9 \mathrm{k}$

$\mathrm{HO1}: 47 \quad 048.5^{\circ} \mathrm{C} \quad 092.2 \mathrm{~K}$

H06: $47 \quad 069.2^{\circ} \mathrm{C} 098.1 \mathrm{k}$

$\mathrm{H} 11: 47 \quad 097.3^{\circ} \mathrm{C} \quad 126.7 \mathrm{k}$

$\mathrm{H} 16: 47 \quad 113.8^{\circ} \mathrm{C} 191.0 \mathrm{~K}$

$\mathrm{H} 21: 47 \quad 121.3^{\circ} \mathrm{C} 226.6 \mathrm{k}$

$\mathrm{S} 22: 35 \quad 122.1^{\circ} \mathrm{C} 230.6 \mathrm{k}$

$\mathrm{S} 23: 35 \quad 123.0^{\circ} \mathrm{C} 233.8 \mathrm{k}$

$\mathrm{S} 24: 35 \quad 122.4^{\circ} \mathrm{C} 227.2 \mathrm{~K}$

$\mathrm{S} 25: 35 \quad 122.6^{\circ} \mathrm{C} \quad 233.5 \mathrm{k}$

$\mathrm{S} 26: 35123.1^{\circ} \mathrm{C} 231.6 \mathrm{k}$

$\mathrm{S} 27: 36 \quad 122.3^{\circ} \mathrm{C} 224.5 \mathrm{~K}$

S28:36 $122.8^{\circ} \mathrm{C} 232.0 \mathrm{~K}$

$\mathrm{S} 29: 36 \quad 123.3^{\circ} \mathrm{C} 229.2 \mathrm{k}$

$\$ 30: 36 \quad 122.3^{\circ} \mathrm{C} 222.6 \mathrm{~K}$

$\mathrm{S} 31: 36 \quad 122.8^{\circ} \mathrm{C} 229.6 \mathrm{~K}$

$\mathrm{S} 32: 36 \quad 123.2^{\circ} \mathrm{C} 226.9 \mathrm{~K}$

$\mathrm{S} 33: 36 \quad 122.4^{\circ} \mathrm{C} 220.5 \mathrm{~K}$

$534: 36 \quad 122.8^{\circ} \mathrm{C} 228.0 \mathrm{~K}$

$\mathrm{S} 35: 36 \quad 123.2^{\circ} \mathrm{C} 225.4 \mathrm{k}$

$\mathrm{S} 36: 36 \quad 122.4^{\circ} \mathrm{C} 219.1 \mathrm{k}$

$\mathrm{S} 37: 36 \quad 122.8^{\circ} \mathrm{C} 226.7 \mathrm{k}$

$\mathrm{S} 38: 36 \quad 123.2^{\circ} \mathrm{C} 224.5 \mathrm{~K}$

$\mathrm{S} 39: 36 \quad 122.5^{\circ} \mathrm{C} 218.3 \mathrm{k}$

$\mathrm{S} 40: 36 \quad 122.6^{\circ} \mathrm{C} 224.5 \mathrm{~K}$

$\mathrm{S} 41: 36 \quad 123.3^{\circ} \mathrm{C} 223.6 \mathrm{~K}$

$\mathrm{S} 42: 35122.5^{\circ} \mathrm{C} 217.9 \mathrm{~K}$

E81:58 $095.1^{\circ} \mathrm{C} 086.1 \mathrm{k}$

Cycle ended

Load number:0180

12/11/2012 18:03:45

Operator:

Autoclave: 1 


\author{
Ver $=$ LabooTn1 \\ Cyc: 4-Liquids \\ Ster Temp: $122^{\circ} \mathrm{C}$ \\ Ster time:020min \\ Dry time:000min \\ 12/11/2012 18:41:41 \\ W00:00 $034.9^{\circ} \mathrm{C} 092.0 \mathrm{~K}$ \\ H01:24 $038.8^{\circ} \mathrm{C} 092.5 \mathrm{~K}$ \\ H06:24 $068.0^{\circ} \mathrm{C} 097.0 \mathrm{~K}$ \\ $\mathrm{H} 11: 24 \quad 092.0^{\circ} \mathrm{C} 110.3 \mathrm{~K}$ \\ Hi6: $24 \quad 109.4^{\circ} \mathrm{C} 167.6 \mathrm{k}$ \\ $\mathrm{H} 21: 24 \quad 120.4^{\circ} \mathrm{C} 218.6 \mathrm{~K}$ \\ $\mathrm{S} 23: 36 \quad 122.2^{\circ} \mathrm{C} 227.5 \mathrm{k}$ \\ $\mathrm{S} 24: 36 \quad 123.1^{\circ} \mathrm{C} 232.2 \mathrm{~K}$ \\ $\mathrm{S} 25: 37 \quad 122.5^{\circ} \mathrm{C} 226.0 \mathrm{k}$ \\ $\mathrm{S} 26: 37 \quad 122.5^{\circ} \mathrm{C} \quad 230.8 \mathrm{~K}$ \\ $\mathrm{S} 27: 37 \quad 123.3^{\circ} \mathrm{C} 229.9 \mathrm{~K}$ \\ $\mathrm{S} 28: 37 \quad 122.5^{\circ} \mathrm{C} 223.3 \mathrm{k}$ \\ S29:37 $122.6^{\circ} \mathrm{C} 229.8 \mathrm{~K}$ \\ S30:37 $123.1^{\circ} \mathrm{C} 227.6 \mathrm{~K}$ \\ S31:37 122. $4^{\circ} \mathrm{C} 221.1 \mathrm{k}$ \\ S32:37 $122.7^{\circ} \mathrm{C} 228.0 \mathrm{~K}$ \\ $\$ 33: 37 \quad 123.3^{\circ} \mathrm{C} 226.6 \mathrm{~K}$ \\ S34:37 $122.6^{\circ} \mathrm{C} 220.3 \mathrm{~K}$ \\ $\mathrm{S} 35: 37 \quad 122.5^{\circ} \mathrm{C} 224.6 \mathrm{~K}$ \\ S36:37 $123.2^{\circ} \mathrm{C} 225.1 \mathrm{k}$ \\ $\mathrm{S} 37: 37 \quad 122.5^{\circ} \mathrm{C} 219.2 \mathrm{~K}$ \\ $\mathrm{S} 38: 37 \quad 122.4^{\circ} \mathrm{C} 222.5 \mathrm{~K}$ \\ S39:37 $123.2^{\circ} \mathrm{C} 223.6 \mathrm{~K}$ \\ S40:37 $122.6^{\circ} \mathrm{C} 218.0 \mathrm{~K}$ \\ $S 41: 37 \quad 122.6^{\circ} \mathrm{C} 222.6 \mathrm{k}$ \\ $\mathrm{S} 42: 37 \quad 123.1^{\circ} \mathrm{C} 222.3 \mathrm{~K}$ \\ $S 43: 36 \quad 122.5^{\circ} \mathrm{C} 216.6 \mathrm{~K}$ \\ E83:04 $095.1^{\circ} \mathrm{C} 085.9 \mathrm{~K}$ \\ Cycle ended \\ Load number: 0181 \\ 12/11/2012 20:04:50 \\ Operator: \\ Autoclave: 1
}

Ver $=$ Lab0oTn1

Cyc:4-Liquids

Ster Temp: $122^{\circ} \mathrm{C}$

Ster time:020min

Dry time:000min

12/11/2012 20:44:17

W00:00 $032.5^{\circ} \mathrm{C} 092.3 \mathrm{~K}$

H01:29 $036.5^{\circ} \mathrm{C} \quad 092.3 \mathrm{~K}$

H06:29 $065.0^{\circ} \mathrm{C} 096.5 \mathrm{k}$

$\mathrm{H} 11: 29 \quad 091.1^{\circ} \mathrm{C} 108.3 \mathrm{~K}$

$\mathrm{H} 16: 29 \quad 108.5^{\circ} \mathrm{C} 164.2 \mathrm{~K}$

$\mathrm{H} 21: 29 \quad 120.3^{\circ} \mathrm{C} 217.8 \mathrm{k}$

S24:00 $122.2^{\circ} \mathrm{C} 228.0 \mathrm{~K}$

S25:00 $123.2^{\circ} \mathrm{C} 233.0 \mathrm{~K}$

S26:00 $122.6^{\circ} \mathrm{C} 226.5 \mathrm{k}$

$\mathrm{S} 27: 00 \quad 122.2^{\circ} \mathrm{C} 227.8 \mathrm{~K}$

S28:00 $123.2^{\circ} \mathrm{C} \quad 230.2 \mathrm{k}$

$\mathrm{S} 29: 00 \quad 122.5^{\circ} \mathrm{C} 223.9 \mathrm{k}$

$\mathrm{S} 30: 00 \quad 122.6^{\circ} \mathrm{C} 228.3 \mathrm{~K}$

$\mathrm{S} 31: 00 \quad 123.3^{\circ} \mathrm{C} 228.6 \mathrm{k}$

S32:00 $122.6^{\circ} \mathrm{C} 222.5 \mathrm{k}$

$\$ 33: 00 \quad 122.3^{\circ} \mathrm{C} 224.6 \mathrm{~K}$

$\$ 34: 00 \quad 123.3^{\circ} \mathrm{C} 227.0 \mathrm{~K}$

$\$ 35: 00 \quad 122.6^{\circ} \mathrm{C} 220.8 \mathrm{k}$

$\$ 36: 00 \quad 122.5^{\circ} \mathrm{C} 225.0 \mathrm{~K}$

$\mathrm{S} 37: 00 \quad 123.3^{\circ} \mathrm{C} 225.3 \mathrm{~K}$

S38:00 $122.5^{\circ} \mathrm{C} 218.8 \mathrm{~K}$

$\mathrm{S} 39: 00 \quad 122.6^{\circ} \mathrm{C} 224.7 \mathrm{~K}$

$540: 00 \quad 123.3^{\circ} \mathrm{C} 223.6 \mathrm{k}$

$\$ 41: 00 \quad 122.5^{\circ} \mathrm{C} 217.7 \mathrm{k}$

$\$ 42: 00 \quad 122.5^{\circ} \mathrm{C} 222.6 \mathrm{~K}$

$S 43: 01 \quad 123.3^{\circ} \mathrm{C} 223.2 \mathrm{~K}$

$\mathrm{S} 44: 00 \quad 122.5^{\circ} \mathrm{C} 217.2 \mathrm{k}$

E82: $19 \quad 095.0^{\circ} \mathrm{C} 085.8 \mathrm{k}$

Cycle ended

Load number:0182

12/11/2012 22:06:41

Operator:

Autoclave: 1 


\begin{tabular}{|c|c|}
\hline \multicolumn{2}{|c|}{$\begin{array}{l}\text { Ver }=\text { LabooTn } 1 \\
\text { Cyc: } 4 \text { Liquids } \\
\text { Ster Temp: } 122^{\circ} \mathrm{C} \\
\text { Ster time:020min } \\
\text { Dry time:000min } \\
\text { 12/11/2012 } 22: 11: 08\end{array}$} \\
\hline 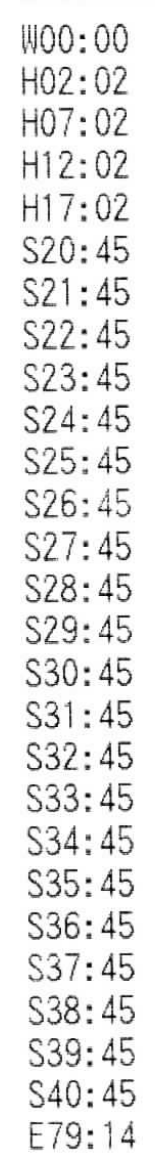 & 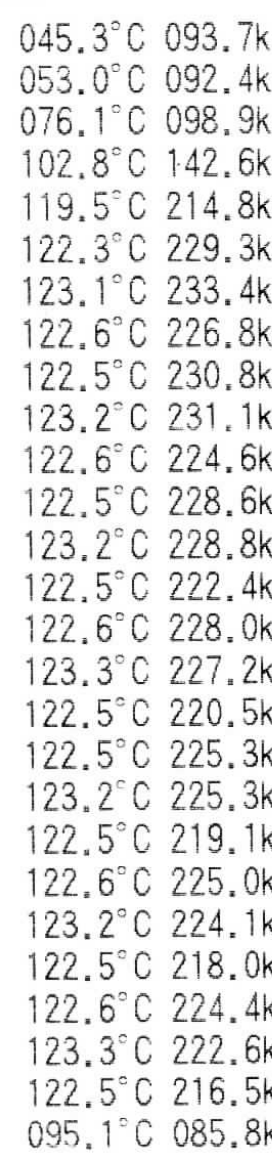 \\
\hline 1 & $\begin{array}{l}\text { de } \\
\text { ber } 0183 \\
12 \text { 23:30:27 } \\
: \\
\text { e: } 1\end{array}$ \\
\hline
\end{tabular}

Ver $=$ LabooTn1

Cyc: 4 ! iquids

Ster Temp: $122^{\circ} \mathrm{O}$

Ster time:020min

Dry time:000min

W00:00 $045.3^{\circ} \mathrm{C} \quad 093.7 \mathrm{k}$

H02:02 $053.0^{\circ} \mathrm{C} \quad 092.4 \mathrm{~K}$

H07:02 $076.1^{\circ} \mathrm{C} 098.9 \mathrm{~K}$

$\mathrm{H} 17.02-119.5^{\circ} \mathrm{C} 214.8 \mathrm{~K}$

$\mathrm{S} 20: 45 \quad 122.3^{\circ} \mathrm{C} 229.3 \mathrm{~K}$

$\$ 21: 45 \quad 123.1^{\circ} \mathrm{C} 233.4 \mathrm{~K}$

S22:45 $122.6^{\circ} \mathrm{C} 226.8 \mathrm{~K}$

$\mathrm{S} 23: 45 \quad 122.5^{\circ} \mathrm{C} 230.8 \mathrm{~K}$

$\mathrm{S} 24: 45 \quad 123.2^{\circ} \mathrm{C} 231.1 \mathrm{k}$

$\$ 26.45 \quad 1225^{\circ} \mathrm{C} 228.6 \mathrm{~K}$

$\mathrm{S} 27: 45 \quad 123.2^{\circ} \mathrm{C} 228.8 \mathrm{~K}$

$\mathrm{S} 28: 45 \quad 122.5^{\circ} \mathrm{C} 222.4 \mathrm{k}$

$\mathrm{S} 29: 45 \quad 122.6^{\circ} \mathrm{C} 228.0 \mathrm{~K}$

$\mathrm{S} 30: 45 \quad 123.3^{\circ} \mathrm{C} 227.2 \mathrm{~K}$

$332.45-122.5^{\circ} \mathrm{C} 225.3 \mathrm{k}$

S33:45 123.2 C 225.3k

$\mathrm{S} 34: 45 \quad 122.5^{\circ} \mathrm{C} 219.1 \mathrm{k}$

S35: $45 \quad 122.6^{\circ} \mathrm{C} 225.0 \mathrm{~K}$

$\mathrm{S} 36: 45 \quad 123.2^{\circ} \mathrm{C} 224.1 \mathrm{~K}$

$\$ 37: 45 \quad 122.5^{\circ} \mathrm{C} 218.0 \mathrm{~K}$

$539.45 \quad 123.3^{\circ} \mathrm{C} 222.6 \mathrm{k}$

$S 40: 45 \quad 122.5^{\circ} \mathrm{C} 216.5 \mathrm{~K}$

$\mathrm{E} 79: 14 \quad 095.1^{\circ} \mathrm{C} \quad 085.8 \mathrm{k}$

Cycle ende

Operator:

Autoclave: 1
Ver $=$ LabooTn1
Cyc:4-Liquids
Ster Temp: $122^{\circ} \mathrm{C}$
Ster time:020min
Dry time:000min

25/11/2012 14:07:36

W00:00 $024.3^{\circ} \mathrm{C} \quad 092.1 \mathrm{k}$

$\mathrm{H} 01: 42 \quad 024.5^{\circ} \mathrm{C} \quad 092.4 \mathrm{k}$

$\mathrm{H} 06: 42 \quad 036.0^{\circ} \mathrm{C} \quad 094.1 \mathrm{k}$

$\mathrm{H} 11: 42 \quad 074.2^{\circ} \mathrm{C} \quad 094.9 \mathrm{~K}$

$\mathrm{H} 16: 42 \quad 097.9^{\circ} \mathrm{C} 123.9 \mathrm{~K}$

$\mathrm{H} 21: 42 \quad 115.4^{\circ} \mathrm{C} 194.5 \mathrm{~K}$

$\mathrm{H} 26: 42 \quad 121.8^{\circ} \mathrm{C} 225.3 \mathrm{~K}$

S27:07 $122.1^{\circ} \mathrm{C} 226.7 \mathrm{k}$

S28:07 $123.0^{\circ} \mathrm{C} 231.1 \mathrm{k}$

$\mathrm{S} 29: 07 \quad 122.4^{\circ} \mathrm{C} 224.5 \mathrm{~K}$

S30:07 $122.8^{\circ} \mathrm{C} 231.0 \mathrm{~K}$

$\mathrm{S} 31: 07 \quad 122.8^{\circ} \mathrm{C} 226.3 \mathrm{~K}$

S32:07 $122.2^{\circ} \mathrm{C} 225.4 \mathrm{k}$

S33:07 $123.2^{\circ} \mathrm{C} 227.8 \mathrm{k}$

S34:08 $122.5^{\circ} \mathrm{C} 221.3 \mathrm{~K}$

$\mathrm{S} 35: 08 \quad 122.8^{\circ} \mathrm{C} 227.5 \mathrm{~K}$

$\mathrm{S} 36: 08 \quad 123.0^{\circ} \mathrm{C} 224.1 \mathrm{k}$

$\mathrm{S} 37: 08 \quad 122.2^{\circ} \mathrm{C} 221.3 \mathrm{~K}$

S38:08 $123.4^{\circ} \mathrm{C} 226.9 \mathrm{k}$

$\mathrm{S} 39: 08 \quad 122.8^{\circ} \mathrm{C} 220.5 \mathrm{~K}$

$\$ 40: 08 \quad 122.5^{\circ} \mathrm{C} 224.1 \mathrm{~K}$

$\mathrm{S} 41: 08 \quad 123.1^{\circ} \mathrm{C} 224.0 \mathrm{~K}$

$S 42: 08 \quad 122.5^{\circ} \mathrm{C} 217.5 \mathrm{k}$

$\mathrm{S} 43: 08 \quad 123.0^{\circ} \mathrm{C} 225.2 \mathrm{k}$

$\mathrm{S} 44: 08 \quad 123.1^{\circ} \mathrm{C} 221.7 \mathrm{k}$

S45:08 $122.3^{\circ} \mathrm{C} 216.1 \mathrm{k}$

S46:08 $123.2^{\circ} \mathrm{C} 224.0 \mathrm{~K}$

S47:07 $122.8^{\circ} \mathrm{C} 218.6 \mathrm{~K}$

E84: $45 \quad 095.1^{\circ} \mathrm{C} \quad 086.3 \mathrm{~K}$

Cycle ended

Load number: 0185

25/11/2012 15:32:26

Operator:

Autoclave: 1 


\begin{tabular}{|c|c|}
\hline $\begin{array}{l}\text { Ver }= \\
\text { Cyc: } 4-1 \\
\text { Ster T } \\
\text { Ster t } \\
\text { Dry t } \\
01 / 12 /\end{array}$ & $\begin{array}{l}\text { booTn1 } \\
\text { quids } \\
\text { p: } 122^{\circ} \mathrm{C} \\
\text { e:020min } \\
\text { e:000min } \\
12 \quad 17: 38: 13\end{array}$ \\
\hline $0: 00$ & $023.8^{\circ} \mathrm{C} \quad 091.6 \mathrm{~K}$ \\
\hline $1: 38$ & $023.8^{\circ} \mathrm{C} 092.0 \mathrm{~K}$ \\
\hline HO6: 38 & $037.5^{\circ} \mathrm{C} \quad 093.5 \mathrm{~K}$ \\
\hline $\mathrm{H} 11: 38$ & $080.5^{\circ} \mathrm{C} \quad 095.5 \mathrm{~K}$ \\
\hline $\mathrm{H} 16: 38$ & $102.6^{\circ} \mathrm{C} 140.6 \mathrm{k}$ \\
\hline $\mathrm{H} 21: 39$ & $119.6^{\circ} \mathrm{C} 214.6 \mathrm{k}$ \\
\hline$S 25: 57$ & $122.2^{\circ} \mathrm{C} 227.8 \mathrm{~K}$ \\
\hline S26:57 & $123.1^{\circ} \mathrm{C} 232.6 \mathrm{k}$ \\
\hline S27:57 & $122.4^{\circ} \mathrm{C} 225.1 \mathrm{k}$ \\
\hline S28:57 & $123.1^{\circ} \mathrm{C} 232.8 \mathrm{k}$ \\
\hline S29: 57 & $123.0^{\circ} \mathrm{C} 227.8 \mathrm{~K}$ \\
\hline S30:57 & $122.2^{\circ} \mathrm{C} 225.4 \mathrm{k}$ \\
\hline S31:57 & $123.3^{\circ} \mathrm{C} 229.5 \mathrm{~K}$ \\
\hline S32:57 & $122.6^{\circ} \mathrm{C} 222.5 \mathrm{k}$ \\
\hline S33: 57 & $122.8^{\circ} \mathrm{C} 229.3 \mathrm{~K}$ \\
\hline S34:57 & $123.3^{\circ} \mathrm{C} 226.6 \mathrm{~K}$ \\
\hline S35:57 & $122.3^{\circ} \mathrm{C} 219.5 \mathrm{k}$ \\
\hline S36:57 & $123.1^{\circ} \mathrm{C} 228.5 \mathrm{k}$ \\
\hline S37:57 & $123.2^{\circ} \mathrm{C} 223.9 \mathrm{~K}$ \\
\hline S38:57 & $122.1^{\circ} \mathrm{C} 218.1 \mathrm{k}$ \\
\hline S39:58 & $123.3^{\circ} \mathrm{C} 226.5 \mathrm{k}$ \\
\hline$S 40: 58$ & $122.8^{\circ} \mathrm{C} 221.0 \mathrm{~K}$ \\
\hline$S 41: 58$ & $122.2^{\circ} \mathrm{C} 219.5 \mathrm{k}$ \\
\hline$\$ 42: 58$ & $123.3^{\circ} \mathrm{C} 225.1 \mathrm{k}$ \\
\hline$\$ 43: 58$ & $122.8^{\circ} \mathrm{C} 219.0 \mathrm{~K}$ \\
\hline S44:58 & $122.5^{\circ} \mathrm{C} 222.0 \mathrm{~K}$ \\
\hline$S 45: 57$ & $123.3^{\circ} \mathrm{C} 222.6 \mathrm{~K}$ \\
\hline E81:06 & $095.0^{\circ} \mathrm{C} 086.1 \mathrm{~K}$ \\
\hline
\end{tabular}

Cycle ended

Load number: 0188

01/12/2012 18:59:24

Operator:

Autoclave: 1 